ISSN 2450-8055

eISSN 2543-8867

\title{
ZESZYTY NAUKOWE
}

Szkoły Głównej Gospodarstwa Wiejskiego

w Warszawie

\section{EKONOMIKA}

i ORGANIZACJA

LOGISTYKI

\section{4 (2) 2019}




\title{
ZESZYTY NAUKOWE
}

Szkoły Głównej Gospodarstwa Wiejskiego

\author{
w Warszawie
}

\section{EKONOMIKA \\ i ORGANIZACJA \\ LOGISTYKI}

Wybrane komponenty łańcuchów dostaw

Redakcja naukowa

Elżbieta J. Szymańska

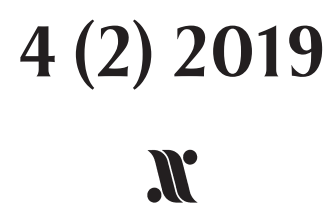

Wydawnictwo SGGW

Warszawa 2019 


\section{RADA NAUKOWA}

Bogdan Klepacki, Szkoła Główna Gospodarstwa Wiejskiego w Warszawie (przewodniczący)

Theodore R. Alter, Pennsylvania State University, USA; Spyros Binioris, Technological Educational Institute of Athens, Grecja; Georgij Cherevko, Lviv State Agrarian University, Ukraina; James W. Dunn, Pennsylvania State University, USA; Wojciech Florkowski, University of Georgia, USA; Elena Horska, Slovak University of Agriculture in Nitra, Słowacja; Marianna Jacyna, Politechnika Warszawska; Qi Jun Jiang, Shanghai Ocean University, Chińska Republika Ludowa; Stanisław Krzyżaniak, Instytut Logistyki i Magazynowania w Poznaniu; Radim Lenort, Technical University of Ostrava, Republika Czeska; Iwo Nowak, redaktor naczelny czasopisma „Logistyka”; Olena Slavkowa, Sumy State University, Ukraina; Bojan Rosi, University of Maribor, Słowenia; Henryk Runowski, Szkoła Główna Gospodarstwa Wiejskiego w Warszawie; Elżbieta J. Szymańska, Szkoła Główna Gospodarstwa Wiejskiego w Warszawie; Maria Tsirintani, Technological Educational Institute of Athens, Grecja

\section{KOMITET REDAKCYJNY}

Elżbieta J. Szymańska (redaktor naczelna)

Aneta Bełdycka-Bórawska (redaktor języka angielskiego); Joanna Baran (redaktor tematyczny - magazynowanie); Aleksandra Górecka (redaktor tematyczny - infrastruktura); Konrad Michalski (redaktor tematyczny - systemy logistyczne); Tomasz Rokicki (redaktor tematyczny - transport i spedycja); Hubert Szczepaniuk (redaktor tematyczny - systemy informatyczne w logistyce); Elżbieta J. Szymańska (redaktor tematyczny - łańcuchy dostaw); Marcin Wysokiński (redaktor tematyczny - materiały niebezpieczne i BHP)

Konrad Michalski (sekretarz)

Arkadiusz Gromada (korektor techniczny)

strona www: eiol.wne.sggw.pl

Projekt okładki - Maria Zych-Lewandowska

Redaktor - Dominika Cichocka

Redaktor techniczny - Violetta Kaska

ISSN 2450-8055 eISSN 2543-8867 ISBN 978-83-7583-886-2

Wydawnictwo SGGW

ul. Nowoursynowska 166, 02-787 Warszawa

tel. 225935520 (-22, -25 - sprzedaż)

e-mail: wydawnictwo@sggw.pl

www.wydawnictwosggw.pl

Druk / Printed by: ZAPOL sp.j., al. Piastów 42, 71-062 Szczecin 


\section{Spis treści}

\section{Contents}

\section{Teresa Gadek-Hawlena, Katarzyna Krawiec}

Perspektywy rozwoju autonomicznego transportu drogowego towarów, cz. 2

Prospects for the development of autonomous road transport of goods, part 2

\section{Marcin Jurczak}

Koncepcje zrównoważonej logistyki miejskiej w wybranych polskich miastach

Sustainable city logistics ideas in selected Polish cities

\section{Dorota Klepacka-Sulima, Bogdan Klepacki}

Stan infrastruktury drogowej województw o najniższym poziomie rozwoju w Polsce

The state of road infrastructure of voivodships with the lowest development level in Poland

\section{Dorota Krupnik}

Bezpieczeństwo zarządzania łańcuchem dostaw biomasy

Safety security of biomass supply chain management

\section{Konrad Michalski, Monika Kowalewska}

Władza menedżera logistyki kontraktowej w łańcuchu dostaw

The authority of the contract logistics manager in supply chain

\section{Maria Michalowska, Nina Wielgórska}

Możliwości usprawnienia procesu dystrybucji produktów tłuszczowych na przykładzie

firmy branży FMCG

Improvement possibilities of the distribution process of oils and fats on the example

of a FMCG company

\section{Marcin Rabe}

Rozwój i konkurencyjność transportu towarów koleją w Polsce

Development and competitiveness of rail transport in Poland

\section{Elïbieta Jadwiga Szymańska, Edyta Workowska}

Podsystemy zaopatrzenia i dystrybucji w gospodarstwach trzodowych o różnej skali produkcji

Supply and distribution subsystems on pig farms with various production scale

\section{Agnieszka Tluczak}

Równowaga długookresowa pomiędzy cenami w łańcuchu dostaw na rynku mleka Long-term relation between prices in the supply chain on the milk market 



\title{
Ekonomika i Organizacja Logistyki \\ 4 (1), 2019, 5-12
}

DOI: 10.22630/EIOL.2019.4.2.10

\author{
Teresa Gqqdek-Hawlena ${ }^{1}$, Katarzyna Krawiec ${ }^{2}$ \\ ${ }^{1}$ Uniwersytet Ekonomiczny w Katowicach \\ ${ }^{2}$ C. Hartwig Gdynia S.A., Katowice
}

\section{Perspektywy rozwoju autonomicznego transportu drogowego towarów, cz. $2^{1}$ \\ Prospects for the development of autonomous road transport of goods, part 2}

\begin{abstract}
Synopsis. Autonomiczne pojazdy ciężarowe w tym platooning, pomimo że jest już od kilku lat testowany w Europie, wciąż jest mało rozpoznawalny w Polsce. Możliwość zastosowania nowych rozwiązań w kraju wiąże się w pierwszej kolejności z wiedzą na ich temat wśród podmiotów sektora TSL. W artykule zaprezentowano wyniki badań ankietowych przeprowadzonych wśród osób pracujących w sektorze TSL, których celem było określenie poziomu ich wiedzy na temat ciężarowych pojazdów autonomicznych, ocena możliwości testowania systemu platooning na terytorium Polski oraz wskazanie zalet i wad wdrożenia tego typu rozwiązania w kraju.
\end{abstract}

Słowa kluczowe: autonomiczne pojazdy ciężarowe, platooning, podmioty sektora TSL

Summary. Autonomous heavy goods vehicles, including platooning, although it has been tested in Europe for several years, is still not very recognizable in Poland. The possibility of applying new solutions in the country is primarily associated with knowledge about them among entities of the TSL sector. In the article results of the questionnaire survey conducted amongst persons working in the TSL sector were presented, of which determining the level of their knowledge about autonomous trucks, was a purpose, assessment of the possibilities of testing the system platooning to territory of Poland and indicating the merits and demerits of implementing the solution of this type in the country.

Key words: autonomous trucks, platooning, entities of the TSL sector

\footnotetext{
${ }^{1} \mathrm{~W}$ artykule pominięto teoretyczne rozważania dotyczące pojazdów autonomicznych i możliwości ich zastosowania. Artykuł stanowi integralną część opracowania, pt.: Gądek-Hawlena T., Krawiec K., 2018: Perspektywy rozwoju autonomicznego transportu drogowego towarów - cz. 1, Zeszyty Naukowe Szkoły Głównej Gospodarstwa Wiejskiego w Warszawie, Ekonomika i Organizacja Logistyki, 4, 17-25.
} 


\section{Wstęp}

Wdrożenie i wykorzystywanie autonomicznych pojazdów ciężarowych i systemu platooning w krajach Europy Zachodniej spowoduje potrzebę podjęcia działań w tym zakresie Polsce. Zastosowanie nowego rozwiązania, w tym głównie platooningu wiąże się z podjęciem działań w wielu obszarach w tym w zakresie dostosowania infrastruktury transportu, przepisów prawa czy ubezpieczeń. Jako jeden z ważniejszych aspektów mogących mieć istoty wpływ na rozwój tej formy przewozu ładunków w transporcie drogowym jest odpowiednia wiedza na jej temat wśród podmiotów sektora TSL. Przykładem znaczenia odpowiedniej wiedzy na temat platooningu może być sposób przygotowywania European Truck Platooning Challenge [2016].

Celem artykułu była ocena poziomu wiedzy na temat pojazdów autonomicznych i systemu platooning wśród pracowników podmiotów sektora TSL, w tym znajomości przez nich zalet i wad jego zastosowania oraz stanu przystosowania Polski do testowania tego typu rozwiązania. Dla zobrazowania podjętego problemu wykorzystano dane pierwotne uzyskane za pomocą kwestionariusza ankiety, a do przedstawienia wyników badań posłużono się analizą częstości.

\section{Metodyka prowadzenia badań}

Podjęty do realizacji problem ze względu bezpośrednie znaczenie dla sektora TSL wpłynął na dobór próby. W badaniu wzięli udział przedstawiciele kierowców, przedsiębiorców i właścicieli firm transportowych oraz spedytorów, logistyków i dyspozytorów. Badanie było przeprowadzone za pomocą kwestionariusza ankietowego online. Odpowiedzi gromadzone były w dniach $12-14$ czerwca 2018 roku, a do badania przystąpiło 126 respondentów. Kwestionariusz ankiety został podzielony na dwie części. W pierwszej części podjęto próbę zidentyfikowania poziomu wiedzy na temat autonomicznych pojazdów ciężarowych wśród osób pracujących w sektorze TSL. Druga grupa pytań dotyczyła możliwości testowania pojazdów autonomicznych w Polsce.

\section{Charakterystyka próby badawczej}

W badaniu wzięło udział 126 respondentów, z czego 62\% stanowili mężczyźni, a 38\% kobiety. Ankietowani zostali podzieleni na cztery grupy wiekowe. Najliczniejszą grupę spośród badanych stanowiły osoby między 26. a 40. rokiem życia - 50\% wskazań. Kolejną grupą były osoby między 41. a 65. rokiem życia - 32\% wszystkich ankietowanych. Wśród osób między 18. a 25. rokiem życia było 14\% osób ankietowanych. Najmniej liczną grupę wśród respondentów stanowiły osoby powyżej 56. roku życia - 4\%.

Badanie przeprowadzone było wśród osób aktywnych zawodowo, związanych z branżą TSL. Udział poszczególnych grup zawodowych przedstawiał się następująco: spedytorzy, dyspozytorzy i logistycy - 41\% wskazań, przedsiębiorcy i właściciele firm transportowych - 40\% wskazań, kierowcy zawodowi - 29\% wskazań.

Wśród badanych, uwzględniając kryterium - wykształcenie, dominowały osoby z wyższym wykształceniem - 40\% respondentów. Drugą zbiorowością były osoby o wykształceniu średnim - 28\%, następnie osoby o wykształceniu niepełnym wyższym - $16 \%$. 
Osoby mające wykształcenie zawodowe stanowiły 14\% badanych. Najmniej liczną grupą były osoby o wykształceniu podstawowym $-2 \%$.

\section{Poziom wiedzy na temat autonomicznych pojazdów ciężarowych wśród przedstawicieli podmiotów sektora TSL}

W pierwszym pytaniu ankietowani zostali zapytani o to, czy znane jest im pojęcie autonomicznego samochodu ciężarowego. Odpowiedź „tak” zaznaczyło 85\% badanych, a 15\% zdecydowało się na odpowiedź „nie”. Odpowiedź „tak” zaznaczali najczęściej zawodowi kierowcy w wieku pomiędzy 41. a 65. rokiem życia. Z kolei „nie” była odpowiedzią udzielaną przez tą samą grupę zawodową, z tym że były to osoby powyżej 65 lat. To wskazuje na mniejsze zainteresowanie tych osób nowościami w transporcie drogowym.

Drugie pytanie skierowane do ankietowanych dotyczyło znajomości pojęcia platooningu. Wśród badanych 54\% osób wybrało odpowiedź „nie”, z kolei 46\% zaznaczyło odpowiedź „tak”. Najczęściej odpowiedź „tak” wybierana była przez mężczyzn (37 osób). Najliczniejsza grupa wiekowa to przedział pomiędzy 26. a 40. rokiem życia (30 osób). Biorąc pod uwagę wykształcenie, najwięcej ankietowanych z tych, którzy zdecydowali się na odpowiedź „tak” to osoby o wykształceniu średnim (18 osób). Odpowiedź „tak” najczęściej zaznaczali przedsiębiorcy lub właściciele firm transportowych, co może wskazywać na zainteresowanie przedsiębiorców nowym rozwiązaniem. Z kolei odpowiedź „nie” udzielały osoby pracujące na stanowisku spedytora, logistyka lub dystrybutora. Profil osoby decydującej się na odpowiedź „nie” to najczęściej kobieta pracująca na stanowisku spedytora, dyspozytora lub logistyka, będąca w wieku 26-40 lat i mająca wykształcenie wyższe.

Kolejne pytanie zamieszczone w kwestionariuszu ankiety dotyczyło kwestii czy autonomiczne samochody ciężarowe, mogące być samochodami bezzałogowymi, mogą zastąpić konwencjonalne samochody ciężarowe prowadzone przez kierowcę. Aż 44\% badanych wskazało, że nie ma możliwości zastąpienia pojazdów konwencjonalnych pojazdami autonomicznymi. Z kolei 39\% uznało, że taka możliwość istnieje, a 17\% nie miało zdania na ten temat. Spośród 49 ankietowanych, którzy wybrali odpowiedź „tak”, 46 znało wcześniej pojęcie ciężarowego pojazdu autonomicznego, a 26 osób pojęcie platooningu. Wśród 56 osób, które zaznaczyły odpowiedź „nie”, 46 deklarowało wcześniejszą wiedzę na temat ciężarowych pojazdów autonomicznych, a zaledwie 22 osoby wiedzę na temat platooningu.

\section{Zalety i wady pojazdów autonomicznych}

Następnie zapytano respondentów o zalety zastosowania pojazdów autonomicznych (rys. 1). Ankietowani mieli wskazać maksymalnie trzy wyrażenia, które ich zdaniem stanowią najistotniejsze zalety autonomicznych samochodów ciężarowych.

Na podstawie odpowiedzi ankietowanych wskazać można, że trzy najistotniejsze zalety autonomicznych samochodów ciężarowych to kolejno: oszczędność finansowa dla przedsiębiorstw w związku z ograniczeniem zatrudnienia kierowców, możliwość stworzenia nowych zawodów i nowych stanowisk pracy związanych z obsługą autonomicznych systemów w samochodach ciężarowych oraz skrócenie czasu przejazdów w związku z brakiem ograniczeniu czasu pracy. Wśród grupy kierowców zawodowych najczęściej wybierana była odpowiedź: „oszczędność paliwa o około $10 \%$ dzięki poruszaniu się samochodów w konwojach", wśród spedytorów, dyspozytorów lub logistyków najczęściej wybierana 


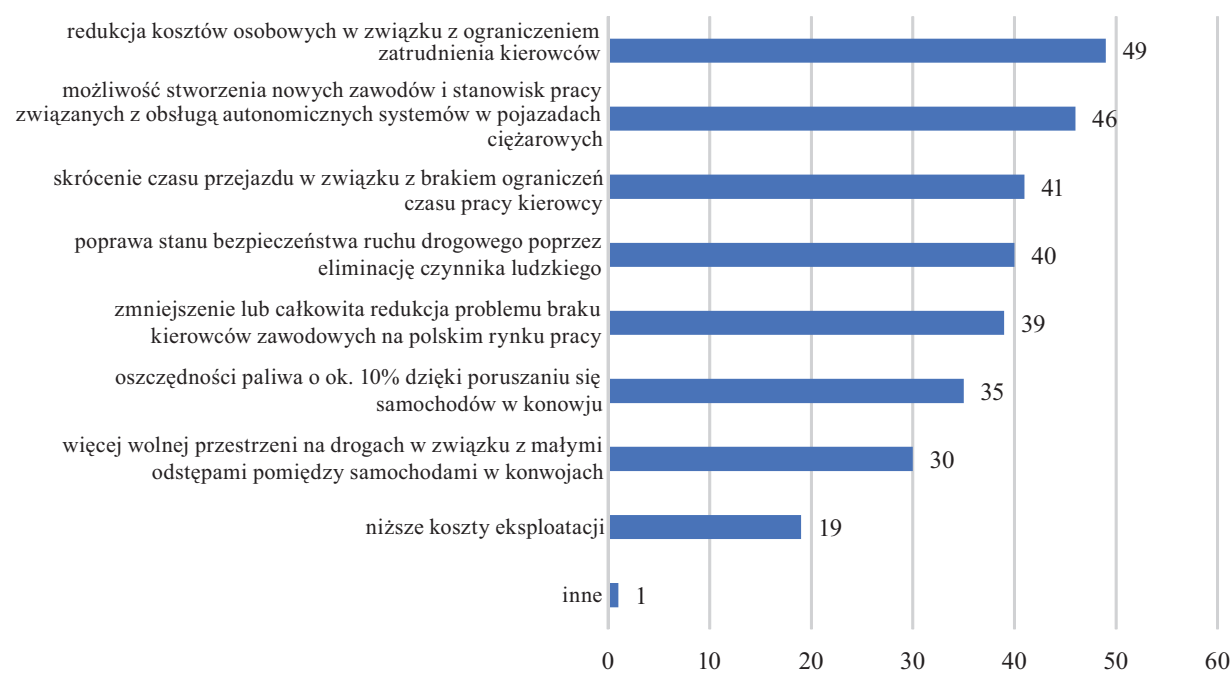

Rysunek 1. Zalety pojazdów autonomicznych

Figure 1. The advantages of autonomous trucks

Źródło: opracowanie własne.

była odpowiedź ,poprawa stanu bezpieczeństwa na drogach w związku z eliminacją czynnika błędu ludzkiego", a pośród przedsiębiorców oraz właścicieli firm transportowych: „oszczędność finansowa dla przedsiębiorstw w związku z ograniczeniem zatrudnienia kierowców”. Najczęściej łączone ze sobą były odpowiedzi dotyczące oszczędności paliwa oraz niższych kosztów eksploatacji. Z opcji wyrażenia własnej opinii w ramach odpowiedzi „,inne” skorzystała jedna osoba, a treść odpowiedzi brzmi: „nie widzę zalet”.

Po wskazaniu zalet przez ankietowanych poproszono o wybór wyrażeń, które w ich opinii są najistotniejszymi wadami autonomicznych samochodów ciężarowych (rys. 2).

Zgodnie z danymi przedstawionymi na rysunku 2, do trzech najpopularniejszych wyrażeń stanowiących wady autonomicznych samochodów ciężarowych zaliczyć można: „pogorszenie się stanu bezpieczeństwa na drogach w związku z możliwością wadliwego oprogramowania samochodów”, „możliwość zhakowania systemu samochodu i zdalne przejęcie kontroli nad nim w celu kradzieży lub zamachu terrorystycznego” oraz „,przewaga dużych firm z dużym kapitałem nad mniejszymi przedsiębiorstwami w związku z większym kosztem zakupu samochodu”. Kierowcy zawodowi najczęściej decydowali się na odpowiedź: „ograniczenie liczby stanowisk pracy dla kierowców zawodowych”, a zarówno spedytorzy, dyspozytorzy i logistycy, jak i przedsiębiorcy oraz właściciele firm transportowych najczęściej wybierali odpowiedź: „możliwość zhakowania systemu samochodu i zdalne przejęcie kontroli nad nim w celu kradzieży lub zamachu terrorystycznego". Kilka odpowiedzi, które najczęściej były wybierane wspólnie, stanowią: „pogorszenie się stanu bezpieczeństwa na drogach w związku z możliwością wadliwego oprogramowania samochodów” oraz „możliwość trudnej współpracy podczas jazdy pojazdów autonomicznych z konwencjonalnymi". Podobnie jak w poprzednim pytaniu, tutaj także jedna osoba zdecydowała się na „inną” odpowiedź, która brzmiała: „trzy możliwości wyboru wad to stanowczo za mało". 


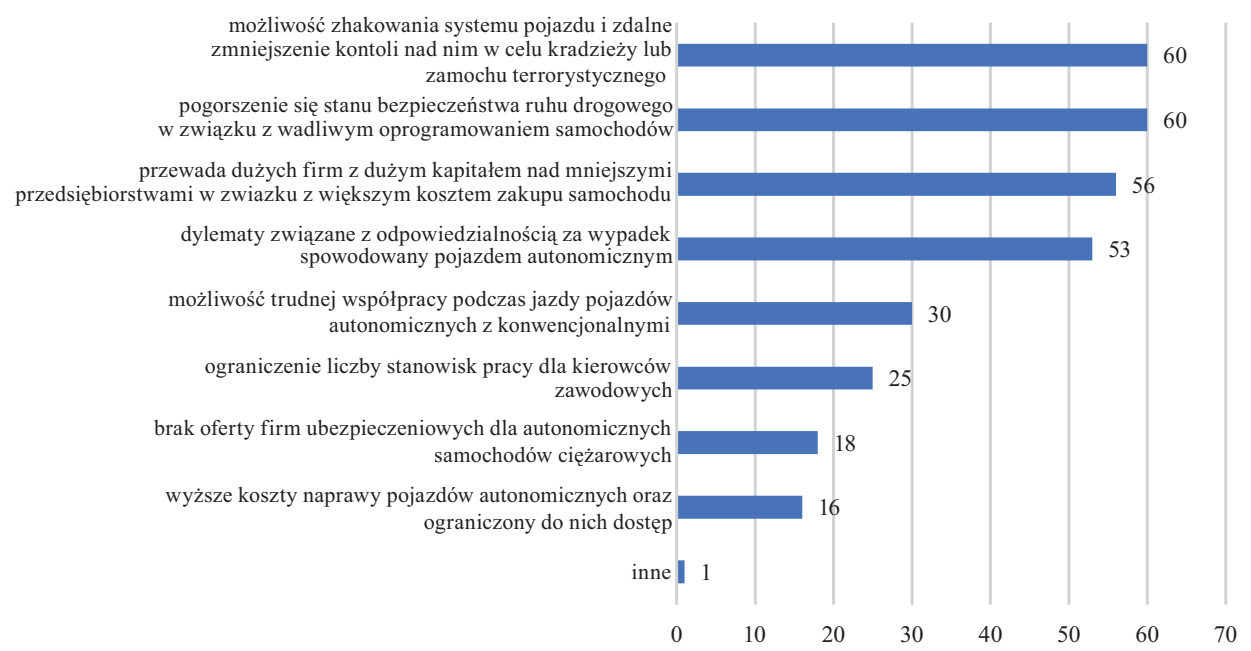

Rysunek 2. Wady pojazdów autonomicznych

Figure 2. The disadvantages of autonomous trucks

Źródło: opracowanie własne.

\section{Przesłanki i bariery testowania ciężarowych pojazdów autonomicznych w Polsce}

Następna grupa pytań rozpoczynała się od udzielenia odpowiedzi przez respondentów na temat możliwości rozpoczęcia testowania autonomicznych samochodów ciężarowych na terytorium Polski. Pytanie zawierało w sobie informacje o tym, że takie systemy są już testowane w różnych krajach europejskich, np. w Niemczech czy Holandii. Wśród respondentów odpowiedź „tak” na temat możliwości rozpoczęcia testowania udzieliło 24\% badanych. Odpowiedzi „nie” udzieliło odpowiedzi 29\% ankietowanych. Aż 47\% badanych wskazała odpowiedź „nie wiem”. Tak duża liczba odpowiedzi „nie mam zdania” może być związana z brakiem wiedzy na temat znajomości pojęć dotyczących autonomicznych pojazdów ciężarowych i platooningu.

Kolejną kwestią podjętą w badaniu było wskazanie najważniejszych przesłanek przemawiających za rozpoczęciem testowania autonomicznych samochodów ciężarowych w Polsce. Udzielone odpowiedzi przedstawiono na rysunku 3.

Ankietowani wskazali, że trzema najistotniejszymi przesłankami do rozpoczęcia testowania autonomicznych samochodów ciężarowych w Polsce są kolejno: ,zlikwidowanie problemu braku kierowców na polskim rynku pracy”, ,impuls motywujący do rozbudowy sieci dróg i autostrad w Polsce” oraz „usprawnienie transportu wewnątrzzakładowego”. Najpopularniejszym wyborem kierowców zawodowych była odpowiedź: „impuls motywujący do rozbudowy sieci dróg i autostrad w Polsce", spedytorów, dyspozytorów i logistyków: „skrócenie czasu transportu”, a według przedsiębiorców i właścicieli firm transportowych: „zlikwidowanie problemu braku kierowców zawodowych na polskim rynku pracy”. Najczęściej łączone ze sobą były następujące dwie odpowiedzi: „skrócenie czasu transportu” oraz „usprawnienie transportu wewnątrzzakładowego”. 


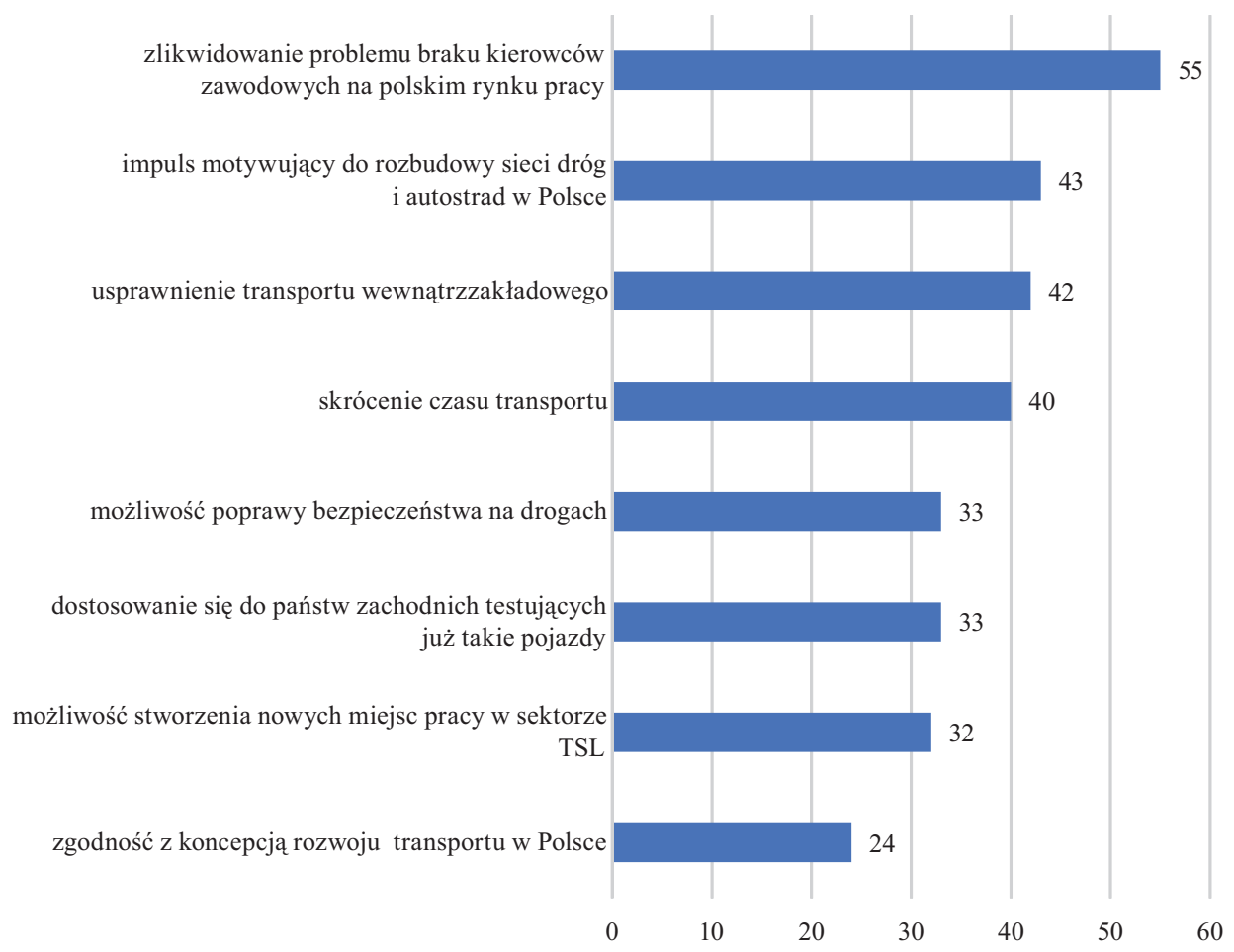

Rysunek 3. Przesłanki przemawiające za testowaniem pojazdów autonomicznych Figure 3. Testing of autonomous trucks

Źródło: opracowanie własne.

Następne pytanie dotyczyło wskazania przeszkód w rozpoczęciu testowania autonomicznych samochodów ciężarowych w Polsce (rys. 4).

Jak wynika z danych przedstawionych na rysunku 4, ankietowani jako trzy najistotniejsze przeszkody w rozpoczęciu testowania autonomicznych samochodów ciężarowych w Polsce wskazali: brak odpowiednich regulacji prawnych i ewentualny długi czas ich projektowania i wdrażania, niewystarczający stan techniczny infrastruktury drogowej oraz zbyt mała liczba autostrad w Polsce. W grupie kierowców zawodowych najpowszechniejszą odpowiedzią był: ,niski poziom kultury jazdy innych uczestników ruchu w pojazdach konwencjonalnych", w grupie spedytorów, dyspozytorów oraz logistyków: „brak odpowiednich regulacji prawnych i ewentualny długi czas ich projektowania i wdrażania", a w grupie przedsiębiorców i właścicieli firm transportowych: „możliwość sprzeciwu kierowców zawodowych prowadzący do buntu i strajków”. Dwie zestawiane ze sobą odpowiedzi to: ,zbyt mała ilość autostrad w Polsce” oraz „brak ciągłości w sieci autostrad w Polsce”. 


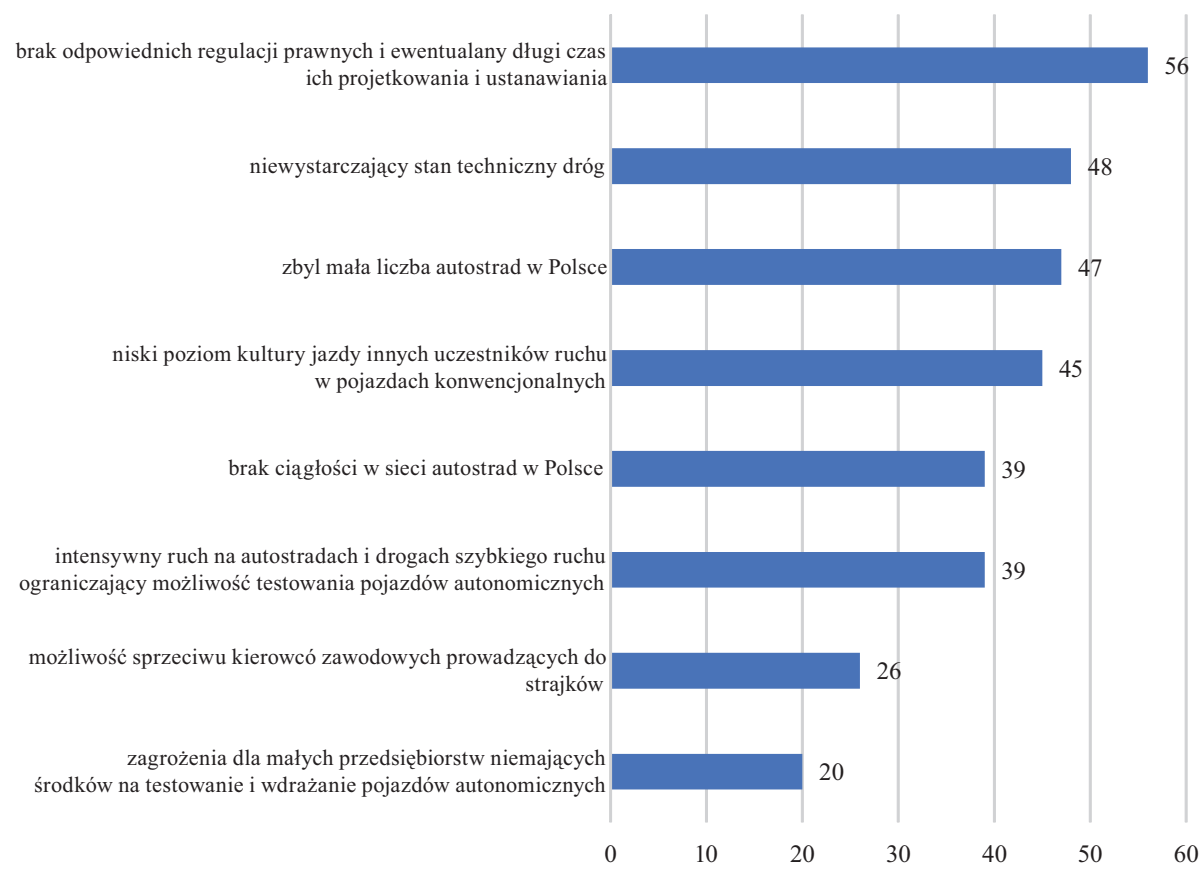

Rysunek 4. Przeszkody w testowaniem pojazdów autonomicznych Figure 4 Obstacles to testing autonomous trucks

Źródło: opracowanie własne.

\section{Podsumowanie i wnioski}

$\mathrm{Na}$ podstawie przeprowadzonych badań można sformułować kilka wniosków i uogólnień:

1. W Polsce wśród pracowników i właścicieli firm sektora TSL jest niski stan wiedzy o pojazdach autonomicznych i systemie platooningu. Jednocześnie największą wiedzę w tym zakresie mieli kierowcy zawodowi, co może wynikać z faktu, że zetknęli się $\mathrm{z}$ testowaniem tego typu rozwiązaniami w krajach Europy Zachodniej, z kolei najmniejszą wiedzę na ten temat mieli spedytorzy, logistycy i dystrybutorzy. Niski poziom wiedzy tej grupy zawodowej może wynikać z charakteru wykonywanej pracy.

2. Wśród zalety autonomicznych samochodów wymienianych przez badanych należy zaliczyć oszczędność finansowa dla przedsiębiorstwa w związku z ograniczeniem zatrudnienia kierowców, możliwość stworzenia nowych zawodów i nowych stanowisk pracy związanych z obsługą autonomicznych systemów w samochodach ciężarowych oraz skrócenie czasu przejazdów w związku z brakiem ograniczenia czasu pracy kierowcy. 
3. Jako najistotniejsze wady zostały wskazane następujące czynniki: pogorszenie się stanu bezpieczeństwa na drogach w związku z możliwością wadliwego oprogramowania samochodów, możliwość zhakowania systemu samochodu i zdalne przejęcie kontroli nad nim w celu kradzieży lub zamachu terrorystycznego oraz dylemat odpowiedzialności za ewentualny wypadek spowodowany przez autonomiczny samochód.

4. Istotnymi przesłankami do rozpoczęcia testowania autonomicznych samochodów ciężarowych w Polsce według ankietowanych było zlikwidowanie problemu braku kierowców zawodowych na polskim rynku pracy, impuls motywujący do rozbudowy sieci dróg i autostrad w Polsce oraz usprawnienie transportu wewnątrzzakładowego.

5. Z kolei trzema najistotniejszymi przeszkodami okazały się kolejno: brak odpowiednich regulacji prawnych i ewentualny długi czas ich projektowania i wdrażania, niewystarczający stan techniczny infrastruktury drogowej oraz zbyt mała ilość autostrad w Polsce.

6. Negatywne podejście podmiotów sektora TSL do kwestii pojazdów autonomicznych w dużej mierze może wynikać z niewystarczającej wiedzy na ich temat, co jednak powinno zmieniać się wskutek coraz szerszego rozpowszechnienia testowania pojazdów autonomicznych w krajach Europy Zachodniej.

\section{Literatura}

European Truck Platooning, 2016: European Truck Platooning Challenge 2016. Hypothesis and recommendations for future cross border Field Operational Tests of truck platooning in Europe, Rijkswaterstaat, Rotterdam, [źródło elektroniczne] https://www.eutruckplatooning.com/Themes/Technical/default.aspx [dostęp: 01.01.2018].

Adres do korespondencji:

dr Teresa Gądek-Hawlena (https://orcid.org/0000-0003-4350-1246) Uniwersytet Ekonomiczny w Katowicach

Wydział Ekonomii

Katedra Transportu ul. 1 Maja 50, 40-287 Katowice e-mail: gadek@ue.katowice.pl

mgr inż. Katarzyna Krawiec

C. Hartwig Gdynia S.A.

ul. Krzywa 21/6, 40-061 Katowice e-mail: ktrznkrwc@gmail.com 


\title{
Ekonomika i Organizacja Logistyki \\ 4 (2), 2019, 13-27
}

DOI: 10.22630/EIOL.2019.4.2.11

\author{
Marcin Jurczak \\ Uniwersytet Ekonomiczny w Poznaniu
}

\section{Koncepcje zrównoważonej logistyki miejskiej w wybranych polskich miastach}

\section{Sustainable city logistics ideas in selected Polish cities}

\begin{abstract}
Synopsis. Zrównoważona mobilność definiowana jest m.in. jako rozwój transportu publicznego, ale także systemów nowoczesnej mobilności - car poolingu, car sharingu, systemów rowerów miejskich czy innych „,wspólnych” pojazdów do przemieszczania się. W artykule przedstawiono wybrane koncepcje z zakresu zrównoważonej mobilności w wybranych polskich miastach. Celem autora była analiza dostępności rozwiązań z zakresu zrównoważonej logistyki miejskiej w największych polskich miastach i ocena, w jakim stopniu mogą być one środkiem do efektywnego przemieszczania w przestrzeni miejskiej. Z badań wynika, że polskie miasta bardzo poważnie podchodzą do tematów zrównoważonej mobilności i oferują mieszkańcom wiele rozwiązań w tym zakresie.
\end{abstract}

Słowa kluczowe: logistyka miejska, transport publiczny, zrównoważony rozwój

\begin{abstract}
Sustainable mobility is defined, among others, as the development of public transport, but also modern mobility systems - car pooling, car sharing, city bike systems or other "common" vehicles to move around. The article presents selected concepts in the field of sustainable mobility in selected Polish cities. The author's goal was to analyse the availability of solutions in the field of sustainable urban logistics in the largest Polish cities and to assess which can be effective in urban space. The research shows that Polish cities take a very serious approach to sustainable mobility issues and offer for their residents many solutions in this area.
\end{abstract}

Key words: city logistics, public transport, sustainable development

\section{Wstęp}

Zrównoważony rozwój ośrodków miejskich stał się tematem niezwykle aktualnym. W literaturze polskiej i światowej znaleźć można wiele publikacji, poruszających temat zrównoważonego rozwoju w odniesieniu do miast, aglomeracji, metropolii. Celem autora była analiza dostępności rozwiązań z zakresu zrównoważonej logistyki miejskiej w największych polskich miastach i ocena, w jakim stopniu mogą być one środkiem do efek- 
tywnego przemieszczania w przestrzeni miejskiej. Autor odnosi się także do konkretnych studiów przypadków. Autor bada, w jaki sposób koncepcje na poziomie teoretycznym przekładają się na konkretne wdrożenia w obszarze systemów transportu publicznego w miastach. Na podstawie zebranych przykładów analizuje, w jakim stopniu nowoczesne koncepcje logistyki miejskiej wdrożone w polskich miastach mają wpływ na kształt miejskich systemów logistycznych. Praktyka pokazuje, że w logistyce miejskiej jest dziś miejsce dla technologii i rozwiązań wspierających zrównoważony rozwój.

\section{Koncepcja logistyki miejskiej}

„Miasto od zarania dziejów jest dla znacznej części ludzkości wymarzonym miejscem realizowania siebie. To miejsce specjalne, dające człowiekowi wiele korzyści, zarówno duchowych, jak i materialnych" [Szołtysek 2016, s. 11]. „Istotą logistyki miasta jest kreowanie mobilności ludzi oraz kształtowanie przepływów dóbr materialnych i informacji. Te działania prowadzone są w ramach systemu logistycznego miasta (...)" [Szołtysek 2016, s. 48]. System ten obejmuje pięć podstawowych subsystemów: transportu zbiorczego i indywidualnego, regulacji - kreowania przemieszczeń dóbr materialnych i ludzi, transportu dóbr materialnych i odpadów komunalnych, składowania dóbr materialnych i odpadów komunalnych oraz przemieszczeń pieszych, rowerowych i innych niezmotoryzowanych [Szołtysek 2016, s. 49]. Zasadniczo problematyka logistyki miejskiej obraca się zatem wokół podstawowych procesów logistycznych (transportu, magazynowania), ale w odniesieniu do miejskiej przestrzeni i grup użytkowników typowych dla miasta.

„Problematyka zarządzania przepływami osób i ładunków w miastach w celu przeciwdziałania kongestii transportowej oraz jej skutkom od co najmniej kilkudziesięciu już lat znajduje się w centrum zainteresowań zarówno inżynierów ruchu, jak i ekonomistów transportu" [Kiba-Janiak i Witkowski 2014, s. 11]. Należy mieć na uwadze, że jak wskazują cytowani autorzy „Nadrzędnym celem w modelowaniu logistyki miejskiej jest poprawa jakości życia mieszkańców" [Kiba-Janiak i Witkowski 2014, s. 27].

Wyzwaniem pozostaje stworzenie mechanizmów sprawnego funkcjonowania procesów z obszaru logistyki miejskiej, odpowiednie ich modelowanie, sprawne zarządzanie, ale i umiejętna analiza efektów. Logistyka miejska to przede wszystkim wykorzystanie określonych narzędzi i pomiary konkretnych efektów.

Logistyka miejska stawia przed sobą następujące cele: łączenie transportów i dopasowanie przepływu towarów poprzez konsolidację frachtów na obrzeżach miast, wyznaczanie wydzielonych pasów transportowych, lub wykorzystanie transportu podziemnego, lub nadziemnego, czy wykorzystanie przyjaznych dla środowiska środków transportu i technologii napędu [Deckert 2018, s. 63-64].

Modelowanie procesów logistyki miejskiej staje się zadaniem coraz bardziej złożonym, wymaga także dużych nakładów finansowych. Nic więc dziwnego, że tak dużym zainteresowaniem ze strony miast cieszą się wszelkie instrumenty wsparcia w tym obszarze. „Utworzenie sprawnego i ekologicznego systemu transportu zbiorowego w mieście, który zaspokoi potrzeby przewozowe i wymagania jakościowe mieszkańców oraz stworzy odpowiednie warunki jego rozwoju, wymaga wielu inwestycji oraz bardzo dużych nakładów. Nie każde miasto dysponuje takimi środkami, dlatego nieocenioną pomoc 
może stanowić wsparcie finansowe ze strony Unii Europejskiej w postaci różnych projektów z obszaru transportu i logistyki miejskiej” [Kot 2013, s. 50].

Należy także zauważyć, że współczesność niesie ze sobą nowe wyzwania, związane m.in. z wykorzystaniem przez miasto nowoczesnych technologii. „W czasach niezwykle szybkiego rozwoju terenów miejskich, jak również transportu oraz możliwości komunikacyjnych, wdrażanie założeń logistyki miejskiej nabrało niebywałego znaczenia. Miasta dążą do jak najlepszej realizacji koncepcji zrównoważonego transportu, a również często decydują się na wdrażanie koncepcji inteligentnego miasta nazywanej SmartCity" [Berlińska i Choma 2018, s. 30]. Koncepcja inteligentnego miasta przyjmuje różne formy - od aplikacji mobilnych, wspierających przemieszczanie się po mieście, uruchamiane na poziomie pojedynczego użytkownika, aż po rozbudowane systemy zarządzania, służące kompleksowemu wsparciu procesów usług publicznych. Idea smart city służy wsparciu zarówno transportu zorganizowanego, motoryzacji indywidualnych, jak i innych usług publicznych, chociażby z zakresu zarządzania bezpieczeństwem czy realizacji innych usług. Idea zrównoważonego rozwoju (nazywanego cora z częściej rozwojem ,trwałym”), jest obecnie wdrażana m.in. poprzez ideę smart city - a wspomniane w dalszej części artykułu studia przypadku to często właśnie rozwiązania z obszaru miasta inteligentnego.

\section{Zrównoważony rozwój w logistyce miejskiej}

Stworzenie równowagi - pomiędzy rozwojem społecznym i ekonomicznym, technologicznym a środowiskowym jest niezbędne do tego, by miasto mogło efektywnie się rozwijać. Sukces odnoszą te miasta, które są w stanie umiejętnie połączyć rozwój w wielu równych obszarach, zarówno tych komplementarnych, jak i przeciwstawnych.

„Miasta, w których istnieją niepożądane zjawiska dużego natężenia ruchu, zanieczyszczenia powietrza, wysokiej uciążliwości akustycznej, degradacji krajobrazu oraz nadmiernego, chaotycznego rozrastania aglomeracji, uznawane są za nieprzyjazne nie tylko dla człowieka, ale również dla funkcjonowania podmiotów gospodarczych. Dlatego też zarządzanie systemem transportu miejskiego w obszarze ludzi powinno stanowić integralny element polityki rozwoju miast. Zadaniem władz samorządowych obok tworzenia ekonomicznych warunków sprzyjających innowacyjności przedsiębiorstw jest także dbanie o rozwój miasta w sferze społecznej i ekologicznej” [Korneć 2018, s. 83].

Jednym z największych wyzwań dla rozwoju miast w obszarze logistyki pozostaje wysoki poziom zmotoryzowania. „Styl życia mieszkańców współczesnych miast został zdominowany przez samochody osobowe. Masowa motoryzacja wpłynęła zarówno pozytywnie, jak i negatywnie na jakość życia” [Wyszomirski 2017, s. 28]. Zdaniem Wyszomirskiego, ma to swoje pozytywne, jak i negatywne konsekwencje. Dzięki samochodom mieszkańcy miast „dysponują elastycznym w ruchu drogowym środkiem transportu, często umożliwiającym podróż w relacji drzwi-drzwi” i ,posiadają pojazd, który w określonym stopniu staje się atrybutem ich pozycji społecznej”. Z kolei jako negatywne aspekty dominacji samochodu wskazać należy kongestię drogową, nadmiar spalin i hałasu, suburbanizację i segregację przestrzenną poszczególnych grup użytkowników miasta [Wyszomirski 2017, s. 28]. 
Model masowej motoryzacji coraz częściej jest przez społeczności lokalne negowany. W dobie walki o miejską przestrzeń, popularne staje się „odzyskiwanie” przestrzeni przejętej przez motoryzację celem przeznaczenia na realizację potrzeb innych użytkowników miasta - pieszych, rowerzystów, pasażerów komunikacji publicznej. Wsparciem jest tutaj ekonomia współdzielenia - im chętniej użytkownicy miasta gotowi będą współdzielić określone zasoby (samochody, miejsca parkingowe i inne), tym większy potencjał w odzyskiwaniu miejskiej przestrzeni. To z jednej strony „współdzielenie”, a z drugiej - udostępnianie zasobów „na żądanie”

„Wydaje się, że model «na żądanie» powinien zyskiwać na popularności przede wszystkim na obszarach zabudowanych, zwłaszcza w miastach. To one powinny być inkubatorem nowych pomysłów w tym zakresie. Miasta winny krzewić ideę ekonomii «na żądanie», bo właśnie tam pomaga ona rozwiązać najważniejszy problem, który dzisiaj hamuje rozwój wielu miast - problem związany z zapewnieniem mobilności. Bliskie wyczerpania są bowiem możliwości obsługi potrzeb mieszkańców w tym zakresie. To nie samochody są bolączką współczesnych miast, nie jest nią także niedorozwój infrastruktury drogowej. Problemem jest obecny sposób ich wykorzystywania” [Szymczak 2018, s. 35].

Trend „ekonomii współdzielenia” i zasobów „na żądanie” współgra z koncepcjami zrównoważonego rozwoju i zrównoważonej mobilności. „Zrównoważona mobilność, prowadząca zasadniczo do rozwoju zrównoważonego transportu, zastępowana pojęciem zrównoważonego systemu transportowego, ma na celu takie planowanie i realizowanie potrzeb transportowych, które z jednej strony poprawiają dostępność do infrastruktury i środków transportu, wskazując na społeczne zadowolenie i uatrakcyjnienie miejskiego stylu życia, a z drugiej przyczynią się do sprawniejszej realizacji priorytetowych zadań przy wykorzystywaniu ekologicznych środków transportu oraz do rozwoju regionów" [Dąbrowski 2017, s. 21].

W praktyce oznacza to zatem realizację potrzeb transportowych miasta z maksymalnym możliwym poszanowaniem przyrody, ale i miejskiej przestrzeni. Przestrzeni, która m.in. poprzez rozwój miast uległa degradacji.

„Rozwój i ekspansja przestrzenna miast była jedną z przyczyn zaburzenia równowagi środowiska naturalnego. Podejście antropocentryczne i próba zupełnego uniezależnienia się od wpływu środowiska doprowadziły do pogorszenia się warunków życia, obciążeń komunikacyjnych, niszczenia ekosystemów i jakości środowiska na terenie miast. Zrównoważony rozwój miast należy odpowiednio zaplanować, gdyż jego wdrożenie wymaga właściwego przeniesienia zasad, biorąc pod uwagę uwarunkowania rozwoju i funkcjonowania miast, a także sposobów osiągnięcia tych celów” [Tundys 2013, s. 50].

„Celami miejskiej logistyki są mobilność, zrównoważenie i zapewnienie zdolności, możliwości do życia. Te trzy filary wskazują wielorakie cele logistyki miejskiej, a osiągnięcie tych celów możliwe jest poprzez efektywne i przyjazne środowisku systemu transportu towarów. Wskazuje się tu wiele kryteriów oceny, takich jak globalna konkurencyjność, efektywność, przyjazność środowisku, zdolność do obniżania zatorów ruchu, bezpieczeństwo publiczne, bezpieczeństwo osobiste, oszczędność zużycia energii czy siła robocza". To dlatego logistyka miejska może być wizualizowana wieloobiektowo, w obszarze optymalizacji wielokryterialnej” [Taniguchi 2015, s. 51].

„Zasadniczo wyróżniamy trzy typy rozwiązań w celu osiągania zrównoważonego rozwoju transportu miejskiego: rozwiązania logistyczne, techniczne i polityczne. Większość 
inicjatyw skupia się tylko na jednym (lub co najwyżej dwóch) kierunkach. Aby poprawić ogólną efektywność logistyki miejskiej, konieczne jest łączenie wskazanych metod i rozwiązań” [Quak i Tavasszy 2011, s. 216]. I choć zasadniczo powyższe zasady wskazani autorzy odnoszą do transportu towarowego, znajdują one zastosowanie także w przypadku optymalizacji transportu w mieście w szerszym kontekście (towarów i pasażerów).

\section{Koncepcje logistyki miejskiej}

Zasadniczo, pod hasłem logistyki miejskiej polskie miasta skupiają się na optymalizacji sposobu przemieszczania się osób. I to właśnie w tym obszarze znaleźć można najwięcej pomysłów i realizacji. W dalszej części artykułu wskazano kilka przypadków rozwiązań, które mają stanowić wsparcie dla zrównoważonej logistyki miejskiej. Do celów badania i analizy porównawczej wybrano trzy miasta Poznań, Wrocław i Kraków. Wyboru dokonano, kierując się uwarunkowaniami społeczno-geograficznymi. W statystyce największych polskich miast czołowe miejsca zajmują: Warszawa

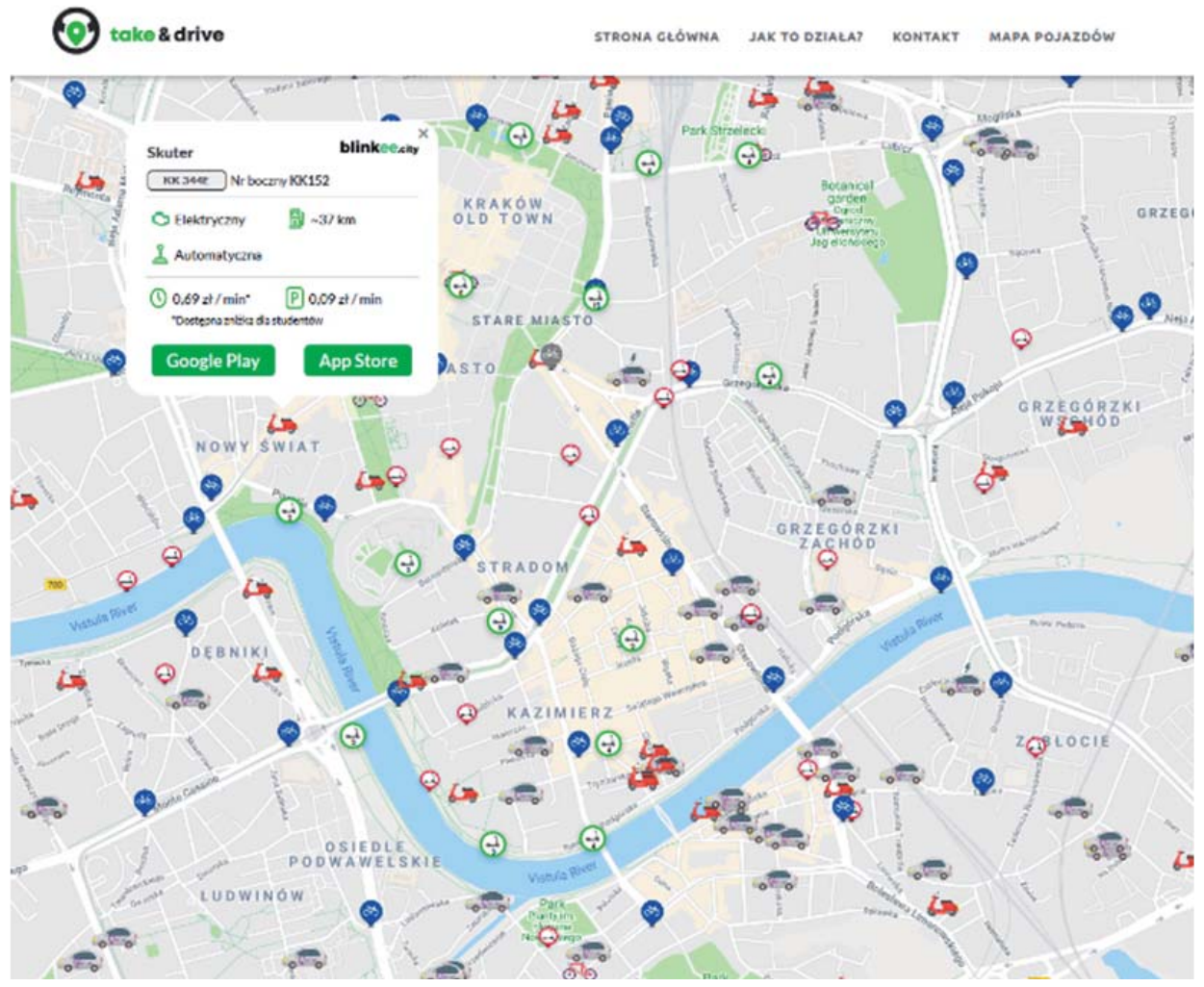

Rysunek 1. Aplikacja Take\&Drive - widok dostępnych pojazdów

Figure 1. Take\&Drive application - available vehicles view

Źródło: https://takeanddrive.eu/map.html [dostęp: 02.05.2019]. 
(1,744 mln mieszkańców), Kraków (761 tys. mieszkańców), Łódź (700 tys. Mieszkańców), Wrocław (635 tys., mieszkańców) i Poznań (542 tys. mieszkańców) ${ }^{1}$. Na tej podstawie podjęto decyzję o wyborze Wrocławia i Krakowa jako miast stanowiących bazę dla porównania z Poznaniem.

Należy zauważyć, że coraz częściej proponowane rozwiązania dostępne są w różnych miastach. To znacznie poprawia ergonomię użytkowania mobilnych użytkowników. Na rynku zaczynają się także pojawiać narzędzia, pozwalające w efektywny sposób poruszać się z wykorzystaniem różnych grup rozwiązań zrównoważonej mobilności - samochodów na minuty, rowerów, czy skuterów. Przykładowy „zrzut ekranu” z takiej aplikacji, przedstawiono na rysunku 1.

\section{Poznań}

Analiza rozwiązań z zakresu logistyki miejskiej w przypadku miasta i aglomeracji poznańskiej opiera się przede wszystkim na rozwiązaniach służących wsparciu transportu osób. Wsparcie miasta dla zrównoważonego rozwoju procesów transportu towarów jest bowiem na relatywnie niskim poziomie i ogranicza się do pojedynczych rozwiązań typu wyznaczone miejsca parkingowe dla dostawców.

„W przypadku Poznania, na podstawie dostępnych informacji, władze miasta nie prowadzą ewidencji danych na temat ilości ładunków transportowanych do i wewnątrz miasta. Nie mniej realizowane są działania zmierzające do poprawienia jakości transportu w mieście, komfortu życia mieszkańców i ochrony terenów zielonych, jak i zabytkowych (ograniczenia ruchu samochodów ciężarowych, strefy ruchu uspokojonego, wprowadzenie rozwiązań preferujących transport publiczny itd.)" [Bojba i in. 2018, s. 30]. Bojba, Kiciński i Merkisz-Guranowska przeprowadzili badania, które, jak prognozują, mogą być „podstawą do wprowadzenia rozwiązań ekologicznej dostawy towarów w Poznaniu, np. takich jak: nocne dostawy towarów, tramwaj towarowy czy centrów konsolidacyjnych". Wynika z nich, że „największy potencjał, jeśli chodzi o miejską dystrybucję towarów w centrum Poznania związany jest z funkcjonowaniem obiektów (punktów) gastronomicznych (...)." [Bojba i in., 2018, s. 37].

Znacznie szerszy zasięg oddziaływania mają narzędzia wspierające transportu publiczny. A jednym z kluczowych obszarów wprowadzania efektywnego transportu publicznego pozostaje nadawanie priorytetu pojazdom na skrzyżowaniach. Rozwiązanie to stosowane jest w Poznaniu od wielu lat, a wraz z wdrożeniem systemu klasy ITS dodatkowo zyskało na znaczeniu. W Poznaniu obecne są priorytety zarówno dla komunikacji autobusowej, jak i tramwajowej. W przypadku tramwajów obsługa pojazdu odbywa się według priorytetu [Gawełek i in., s. 114-115]:

- „brak priorytetu - obsługa według kolejności zgłoszenia,

- niski - obsługa w pierwszej kolejności bez skracania grup kolizyjnych,

- średni - obsługa ze skracaniem grup kolizyjnych, możliwe zatrzymanie,

- wysoki - obsługa ze skracaniem grup kolizyjnych, możliwe spowolnienie,

- pełny - obsługa ze skracaniem grup kolizyjnych bez spowalniania"

\footnotetext{
${ }^{1} \mathrm{https}$ ://stat.gov.pl/statystyka-regionalna/rankingi-statystyczne/miasta-najwieksze-pod-wzgledem-liczby-ludnosci/ [dostęp: 01.05.2019].
} 
Jak thumaczą Gawełek, Góral-Gawełek, Fierek i Pluta [2018], „dla autobusów korzystających ze wspólnego pasa z innymi pojazdami, w przypadku wykrycia obecności pojazdu komunikacji zbiorowej istnieje możliwość preferencji polegającej na wydłużeniu zielonego światła dla kierunku do czasu przejazdu przez linię zatrzymania" [Gawełek i in., s. 115]. Wskazują oni, że w Poznaniu znajduje się łącznie ponad 30 lokalizacji, w których autobusy mają swoje wydzielone pasy, w tym także wydzielone na torowisku czy przyjmujące postać śluz, a ich łączna długość to ponad 13,5 km.

Jednym z najpopularniejszych koncepcji zrównoważonej mobilności w polskich miastach pozostają systemy car sharingu. Z założenia koncepcja ta opiera się na wykorzystaniu pojazdów wypożyczanych na minuty (alternatywnie: godziny, dni), gdy z jednego samochodu korzysta wielu użytkowników. Rozwiązanie to ma pozwolić przede wszystkim na bardziej efektywne gospodarowanie przestrzenią. Z danych operatorów wynika, że jeden samochód współdzielony może zastąpić od 4 do 10 samochodów prywatnych [Bączkowski 2017]. W Poznaniu swoje sieci car sharingu prowadzi obecnie czterech operatorów. Trzech z nich udostępnia samochody klasy popularnej, czwarty - pojazdy marki premium. $Z$ analizy ofert wszystkich czterech operatorów wynika, że zasadniczo są one mocno do siebie zbliżone. Mając rozbudowane floty, operatorzy oferują także wynajem na doby. W przypadku trzech operatorów (4Mobility, Click2Go, EasyShare) flotę stanowią samochody wyposażone w automatyczne skrzynie biegów. W dwóch ostatnich przypadkach - są to pojazdy o napędzie hybrydowym. Z kolei Traficar jako jedyny dostawca może pochwalić się usługą udostępniania pojazdów dostawczych. O ile zwyczajowo możliwe jest pozostawienie samochodu w dowolnym punkcie strefy, o tyle w przypadku samochodów dostawczych Traficar wymagane jest zwrócenie pojazdu do miejsca, z którego został zabrany (co ma swoje logiczne uzasadnienie - pozwala bowiem na maksymalizację ich wykorzystania w punktach startowych - zwykle w okolicach marketów budowlanych). Jeden z operatorów oferuje samochody klasy premium (w Poznaniu: dwa modele Audi) - co ma swoje odzwierciedlenie w nieco wyższych stawkach za czas najmu (czas jazdy i czas postoju). W tabeli 1 zestawiono ofertę czterech systemów car sharingu dostępnych na terenie Poznania. Na rysunku nr 2 przedstawiono jeden z samochodów operatora Traficar.

Ostatni rok upłynął w Poznaniu pod znakiem wprowadzenia do ruchu kolejnego pomysłu na zrównoważoną mobilność - elektrycznej hulajnogi udostępnianej na minuty. Pojazdy te pojawiły się w Poznaniu (a także we Wrocławiu i Warszawie) w grudniu 2018 roku. Od samego początku wzbudziły niemałe kontrowersje. Z uwagi na możliwość pozostawienia w dowolnym miejscu, są one często „parkowane” na chodnikach czy w miejscach potencjalnie kolizyjnych. Sporadycznie zdarza się też, że są one niszczone przez użytkowników [Poznań: Firma Lime...]. Na terenie Poznania korzystać można także ze skuterków elektrycznych - np. 77 pojazdów tego typu udostępnia operator Blinkee, a można je wynająć już od 0,69 PLN/minutę ${ }^{2}$. Skuter elektryczny udostępniany na minuty przedstawiono na rysunku $\mathrm{nr} 3$.

Ważnym elementem zrównoważonej mobilności w Poznaniu jest system rowerów miejskich. Poznański Rower Miejski funkcjonuje od 15 kwietnia 2012 roku, a od 2019 roku obejmuje zarówno system stacyjny (nazywany zwyczajowo rowerem trzeciej

\footnotetext{
${ }^{2}$ https://blinkee.city/pl\#cennik [dostęp: 30.04.2019].
} 


\section{Jurczak}

Tabela 1. Systemy car sharingu w Poznaniu - porównanie

Table 1 Car sharing systems in Poznań - comparison

\begin{tabular}{|c|c|c|c|c|}
\hline Nazwa systemu & 4Mobility & Click2Go & EasyShare & Traficar \\
\hline Flota & Audi A3, Audi Q3 & Toyota Yaris Hybrid & Toyota Yaris Hybrid & $\begin{array}{c}\text { Renault Clio, } \\
\text { Renault Kangoo }\end{array}$ \\
\hline Liczba sam. (po) & 30 & 102 & 200 & ok. $130 *$ \\
\hline Stawka za km & 0,80 PLN & 0,80 PLN & 0,80 PLN & 0,80 PLN \\
\hline $\begin{array}{l}\text { Stawka za minutę } \\
\text { jazdy }\end{array}$ & $\begin{array}{c}0,67(\mathrm{~A} 3), \\
0,75(\mathrm{Q} 3), \\
\text { ceny regularne: } \\
0,85 \text { / 0,95 PLN }\end{array}$ & 0,50 PLN & $\begin{array}{c}0,50 \mathrm{PLN} \\
(\max 50 \mathrm{PLN} / \text { dobę })\end{array}$ & 0,50 PLN \\
\hline $\begin{array}{l}\text { Stawka za minutę } \\
\text { postoju }\end{array}$ & $\begin{array}{l}0,16 \text { PLN (A3), } \\
0,18 \text { PLN (Q3) }\end{array}$ & 0,10 PLN & $\begin{array}{c}0,10 \text { PLN } \\
\text { (godz. } 7-22) \\
0,01 \text { PLN }(22-7)\end{array}$ & 0,10 PLN \\
\hline Miasta & Poznań, Warszawa & Poznań & Poznań, Łódź & $\begin{array}{c}\text { Trójmiasto, } \\
\text { Bydgoszcz, Poznań, } \\
\text { Łódź, Warszawa, } \\
\text { Wrocław, Śląsk, } \\
\text { Kraków, Lublin }\end{array}$ \\
\hline Inne usługi & Wynajem na doby & $\begin{array}{c}\text { Ubezpieczenia, } \\
\text { pakiety } \\
\text { (wynajem na doby) }\end{array}$ & $\begin{array}{l}\text { Wynajem na doby, } \\
\text { rezerwacja biur } \\
\text { i apartamentów }\end{array}$ & $\begin{array}{l}\text { Wynajem aut } \\
\text { dostawczych }\end{array}$ \\
\hline
\end{tabular}

* samochody dostępne w dn. 03.05.2019 wg mapy

Źródło: opracowanie własne na podstawie: www.4mobility.pl, www.click2go.pl, www.easyshare.pl, www.traficar.pl [dostęp: 30.04.2019].

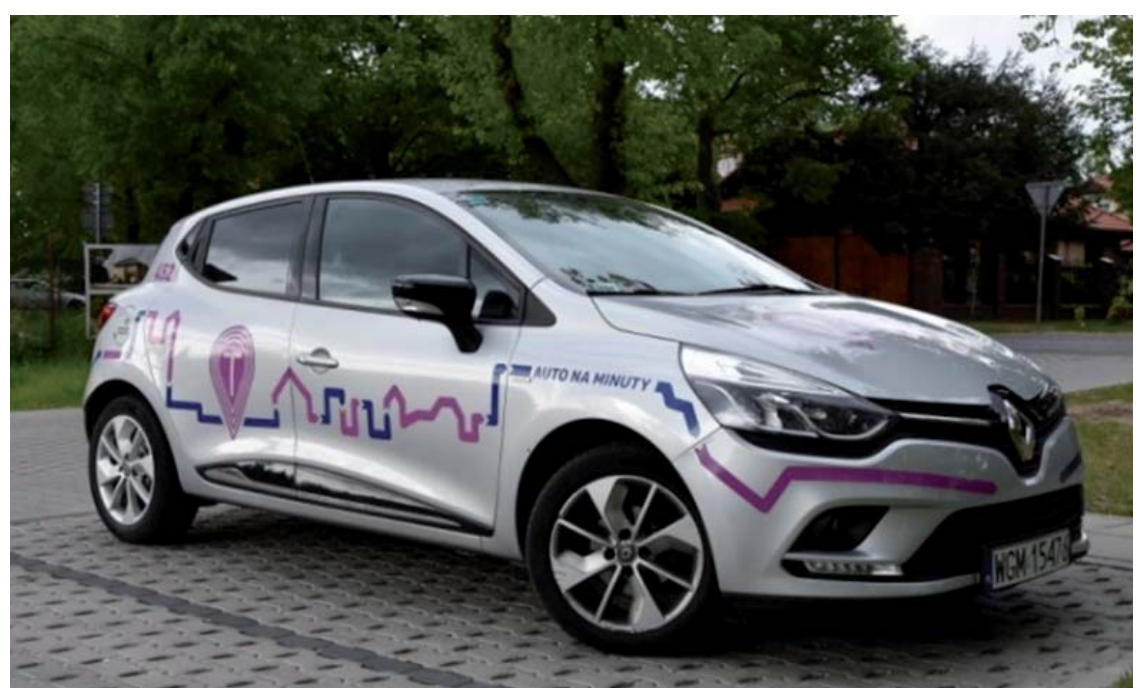

Rysunek 2. Samochód car sharingu w Poznaniu

Figure 2 Car sharing car in Poznań

Źródło: materiały własne autora. 


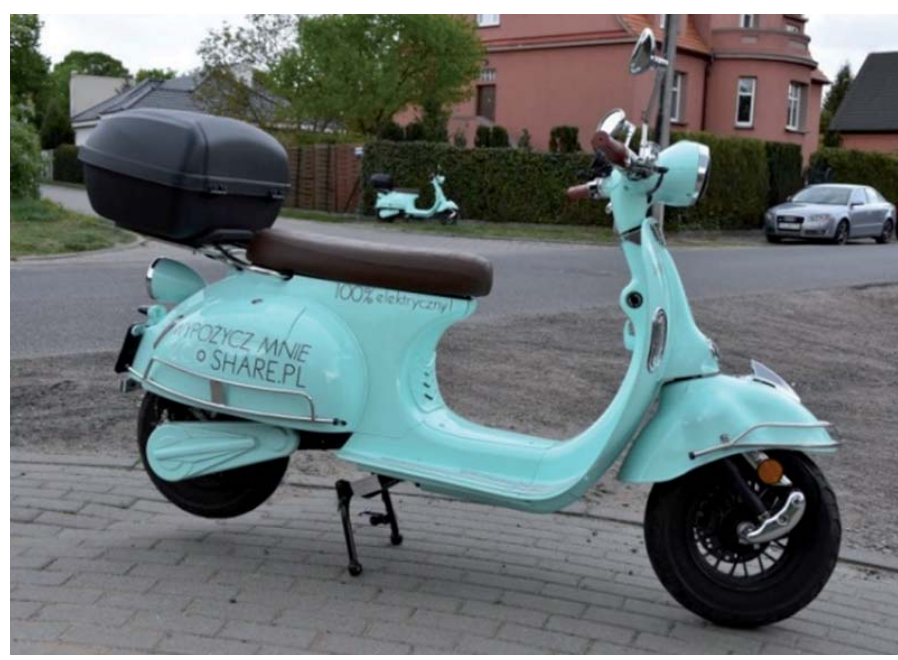

Rysunek 3. Elektryczny skuter w ramach usług „na minuty” w Poznaniu Figure 3 Electric scooter as a part of „per minute” services in Poznań

Źródło: materiały własne autora.

generacji), jak i bezstacyjny (czwartej generacji). Obecnie w systemie obecnych jest ponad 1200 rowerów na 113 stacjach oraz 445 rowerów czwartej generacji (dodatkowo: 30 rowerów elektrycznych czwartej generacji). Dla rowerów czwartej generacji wyznaczono 112 stref, z których 80 znajduje się w pobliżu stacji trzeciej generacji [Poznański Rower...]. System roweru miejskiego w Poznaniu jest mocno rozbudowany, w październiku i listopadzie 2018 roku rozstrzygnięto przetarg na wybór operatora systemu na kolejne trzy lata. Jedyną ofertę w przetargu złożyła spółka NB Poznań Sp. z o.o. i to ona będzie odpowiadała za obsługę Poznańskiego Roweru Miejskiego w latach 2019-2022. Wartość udzielonego zamówienia (na utrzymanie systemu trzeciej generacji i stworzenie systemu czwartej generacji) to $31 \mathrm{mln}$ PLN brutto [Umowy na system..., 2018].

\section{Kraków}

W Krakowie obecne są m.in. skutery Blinkee (aktualnie flota liczy 70 skuterów, są tam także hulajnogi - 14 sztuk). Z kolei system krakowskiego roweru miejskiego (nazwany Wavelo) opiera swoje funkcjonowanie na modelu abonamentowym. Podstawowy pakiet „miesięczny 60” zakłada, że za kwotę 20 PLN miesięcznie, użytkownik ma do dyspozycji rower przez 60 minut dziennie (po tym czasie naliczana jest stawka: 0,05 PLN/minutę). W pakiecie pay as you go wypożyczenie roweru kosztuje obecnie 0,17 PLN za minutę, czyli 10,2 PLN/godzinę ${ }^{3}$. Krakowski system roweru miejskiego cieszy się dużą popularnością. W 2018 roku krakowianie i turyści wypożyczali rowery miejskie ponad 987 tys. razy i pokonali nimi ponad 3,6 mln km. Operatorem krakowskiego systemu ro-

\footnotetext{
${ }^{3}$ https://wavelo.pl/ [dostęp: 30.04.2019].
} 
werów miejskich jest firma BikeU. W 2019 roku do dyspozycji użytkowników ma być flota 1500 rowerów ${ }^{4}$. Krakowski system roweru miejskiego pozostaje aktywny także w sezonie zimowym - po pilotażu w październiku 2016 roku, kiedy to podjęto decyzję o pozostawieniu rowerów także na sezon jesienno-zimowy, w kolejnych zimach system Wavelo także jest aktywny. Zgodnie z zapisami koncesji, w sezonie zimowym dostępne jest 500-550 rowerów. Każdy z nich po przejechaniu $500 \mathrm{~km}$ wysyła do systemu informację o konieczności dokonania kontroli stanu technicznego - przeglądy rowerów mają być sposobem na bezproblemową eksploatację w śniegu i mrozie [Ogórek 2017].

Krakowski Zarząd Infrastruktury Komunalnej i Transportu już od kilku lat zachęca mieszkańców m.in. do carpoolingu - wspólnych dojazdów w kilka osób jednym samochodem. Ma to być odpowiedź na niską efektywność wykorzystania miejskiej przestrzeni przez samochody - z analiz kompleksowego badania ruchu z 2013 roku wynika, że w aż 61,3\% samochodów poruszających się po Krakowie znajduje się tylko jedna osoba [Carpooling czyli...]. W ramach promowania zrównoważonej mobilności uruchomiono stronę internetową - mobilnykrakow.pl. Idea ta jest jak najbardziej słuszna, choć na razie zakres treści na tej stronie jest niestety ograniczony. Podstrony dla rowerzystów i pasażerów komunikacji miejskiej zasilone zostały treścią, podstrony dla pieszych i kierowców pozostają nieaktywne. Miasto Kraków (za pośrednictwem Zarządu Transportu Publicznego) zachęca dostawców do przyłączenia się do pilotażu i testów rowerów towarowych. Zaproszenie skierowane jest do firm, instytucji i organizacji pozarządowych ${ }^{5}$.

Wśród systemów car sharing dostępnych w Krakowie jest m.in. Traficar. Kraków był pierwszym miastem w Polsce, w którym pojawiła się usługa współdzielenia samochodów. Jesienią 2016 roku właśnie w stolicy Małopolski ruszył Traficar, wraz z flotą 100 samochodów marki Opel Corsa [Kraków. Pierwsza w..., 2016]. Obecnie flota ta została mocno rozszerzona. Co ciekawe, Kraków miał też być miastem z systemem car sharingu opartym na samochodach elektrycznych marki BMW i3. System o nazwie Kracar miał być uruchomiony do końca 2018 roku, tak się jednak nie stało. Z 32 stacji ładowania półszybkiego miało korzystać 30 samochodów. Na początku 2019 roku do ładowania było dostępne tylko jedno urządzenie, a samochodów marki BMW i3 z systemu Kracar w dalszym ciągu nie było widać na krakowskich ulicach. System Kracar ma być uruchomiony wtedy, gdy zapewnione zostanie ładowanie dla pojazdów [ALL 2019].

Władze Gminy Miejskiej Kraków oraz spółka GO-EAuto podpisały porozumienie, na mocy której firma ma tworzyć infrastrukturę do ładowania samochodów elektrycznych [Miasto rozwija..., 2018].

\section{Wroclaw}

System car sharingu dostępny jest także we Wrocławiu. W listopadzie 2017 roku wystartował system Vozilla - w pierwszej w Polsce miejskiej wypożyczalni samochodów elektrycznych. Flota tego systemu liczy 200 samochodów elektrycznych, które w ciągu pierwszego roku pokonały łącznie ponad $2 \mathrm{mln} \mathrm{km}$. System ten notuje konsekwentny

\footnotetext{
${ }^{4} \mathrm{https}: / /$ wavelo.pl/wavelo-presspack.zip [dostęp: 30.04.2019].

${ }^{5}$ http://www.ztp.krakow.pl/rowery-towarowe/ [dostęp:02.05.2019].
} 
wzrost zainteresowania wrocławian. W styczniu 2018 roku wypożyczono nim 50 tys. pojazdów, w listopadzie 2018 roku - już 320 tys. Łącznie w systemie obecnych jest ok. 50 tys. użytkowników, rekordzista wypożyczał samochód Vozilli ponad 600 razy [Rok Vozilli..., 2018]. W kwietniu 2019 roku do systemu wprowadzono 50 nowych samochodów marki Renault ZOE, które zastąpiły najbardziej wysłużone samochody marki Nissan Leaf [Renault ZOE..., 2019].

System car sharingu we Wrocławiu jest dobrze rozbudowany, oferuje bowiem zarówno samochody osobowe z napędem elektrycznym (Vozilla), samochody osobowe z napędem spalinowym (Traficar), jak i samochody dostawcze (CityBee). Ciekawą usługą jest ta ostatnia - pozwala ona bowiem na wypożyczenie samochodów dostawczych (marek Fiat Ducato i VW Crafter). Ta ostatnia usługa to rynkowa nowość - samochody z logo CityBee pojawiły się na ulicach polskich miasta w IV kwartale 2018 roku. W ciągu pierwszych trzech miesięcy w usłudze zarejestrowało się ponad 10 tys. użytkowników. Wynajem samochodów dostawczych dostępny jest w 11 polskich miastach, a liczba samochodów to łącznie 150-90 fiatów i 60 volkswagenów. Co ciekawe, możliwe jest wypożyczenie samochodu w jednym mieście i zwrot w drugim [Trzy miesiące..., 2019]. System car sharingu we Wrocławiu uzupełniają pojazdy znane także z innych miast - elektryczne skutery czy hulajnogi (od kwietnia 2019 roku na terenie miasta dostępnych jest 400 pojazdów operatora hive). Koszty wynajmu poszczególnych grup pojazdu (z rozróżnieniem, w jaki sposób opłaty są pobierane) zestawiono w tabeli 2.

System Wrocławskiego Roweru Miejskiego składa się z 1 tys. rowerów czwartej generacji i 65 rowerów niestandardowych. Rowery czwartej generacji można wypożyczać ze 100 stacji na terenie miasta. Sam system powrócił w 2019 roku w nowej odsłonie - do tysiąca rowerów nowej generacji dołączyć ma wkrótce kolejny tysiąc - od czerwca będzie dostępnych także dodatkowych 100 stacji. System dostępny jest przez cały rok, w miesiącach zimowych liczba rowerów zmniejszona zostanie do 600. Wśród rowerów niestandardowych są m.in. rowery familijne typu cargo, tandemy, rowery elektryczne, rowery typu składak czy handbike [Wrocławski Rower..., 2019a, b].

Tabela 2. Wybrane systemy pojazdów współdzielonych we Wrocławiu

Table 2 Selected systems of shared vehicles services in Wrocław

\begin{tabular}{|l|c|c|c|c|c|}
\hline Operator & CityBee & Vozilla & Traficar & GoScooter & Hive \\
\hline $\begin{array}{l}\text { Rodzaj } \\
\text { pojazdów }\end{array}$ & samochody dostawcze & $\begin{array}{c}\text { samochody } \\
\text { osobowe } \\
\text { (elektryczne) }\end{array}$ & $\begin{array}{c}\text { samochody } \\
\text { osobowe } \\
\text { (spalinowe) }\end{array}$ & $\begin{array}{c}\text { skutery } \\
\text { elektryczne }\end{array}$ & $\begin{array}{c}\text { hulajnoga } \\
\text { elektryczna }\end{array}$ \\
\hline $\begin{array}{l}\text { Koszt wynajmu } \\
\text { opłata } \\
\text { początkowa }\end{array}$ & nie dotyczy & nie dotyczy & nie dotyczy & nie dotyczy & 2,50 PLN \\
\hline Stawka za km & $\begin{array}{c}0,99 \text { PLN } \\
\text { (pow. 50 km/dzień) }\end{array}$ & nie dotyczy & $0,80 \mathrm{PLN} / \mathrm{min}$ & nie dotyczy & nie dotyczy \\
\hline $\begin{array}{l}\text { Stawka za } \\
\text { minutę jazdy }\end{array}$ & $\begin{array}{c}0,99 \text { PLN/min, } \\
\text { PLN/h, 219 PLN/dzień }\end{array}$ & $\begin{array}{c}1,10-1,30 \\
\text { PLN/min* }\end{array}$ & $0,50 \mathrm{PLN} / \mathrm{min}$ & $0,69 \mathrm{PLN} / \mathrm{min}$ & 0,45 PLN/min \\
\hline $\begin{array}{l}\text { Stawka za } \\
\text { minutę postoju }\end{array}$ & nie dotyczy & $0,10 \mathrm{PLN} / \mathrm{min}$ & $0,10 \mathrm{PLN} / \mathrm{min}$ & $0,09 \mathrm{PLN} / \mathrm{min}$ & nie dotyczy \\
\hline
\end{tabular}

* stawka (1,10, 1,20 lub 1,30 PLN/min) zależna od strefy zakończenia wypożyczenia

Źródło: opracowanie własne na podstawie: baza danych Take\&Drive, [źródło elektroniczne] https://takeanddrive.eu/map.html [dostęp: 01.05.2019]. 
Jednym z pomysłów na kompleksowe podejście do zarządzania zrównoważoną mobilnością jest tworzenie dokumentów o charakterze strategicznym, wyznaczających potencjał i kierunki rozwoju. Idąc tą drogą, stworzono plan zrównoważonej mobilności miejskiej. „W 2013 roku, Rada Miejska przyjęła Wrocławską Politykę Mobilności (WPM) - strategiczny dokument dotyczący tworzenia optymalnych warunków dla przemieszczenia się osób i towarów w mieście. Polityka jest dokumentem ogólnym, który określa kierunki, w których stronę powinniśmy podążać. Kolejnym krokiem jest stworzenie dokumentu wskazującego konkretne działania, które należy podjąć, aby uchwaloną politykę mobilności realizować. (...) Inaczej mówiąc, Wrocławska Polityka Mobilności opisuje to, co chcemy osiągnąć, Plan zaś opisuje, jak chcemy tego dokonać. Stanowi rozszerzenie i uzupełnienie przyjętej WPM o ważny element doprecyzowujący - wdrożeniowy plan działań operacyjnych. Plan Zrównoważonej Mobilności Miejskiej dla Wrocławia (dalej nazywany Planem, zamiennie PZMM) to dokument, który obejmuje wszystkie aspekty mobilności w mieście oraz w jego otoczeniu” [Plan Zrównoważonej..., 2019].

Plan Zrównoważonej Mobilności Miejskiej dla Wrocławia nakreśla m.in. scenariusze rozwoju miasta $\mathrm{w}$ zależności od sposobu realizowania potrzeb z zakresu mobilności. Celem dokumentu jest m.in. redukowanie udziału transportu samochodowego w ogólnej

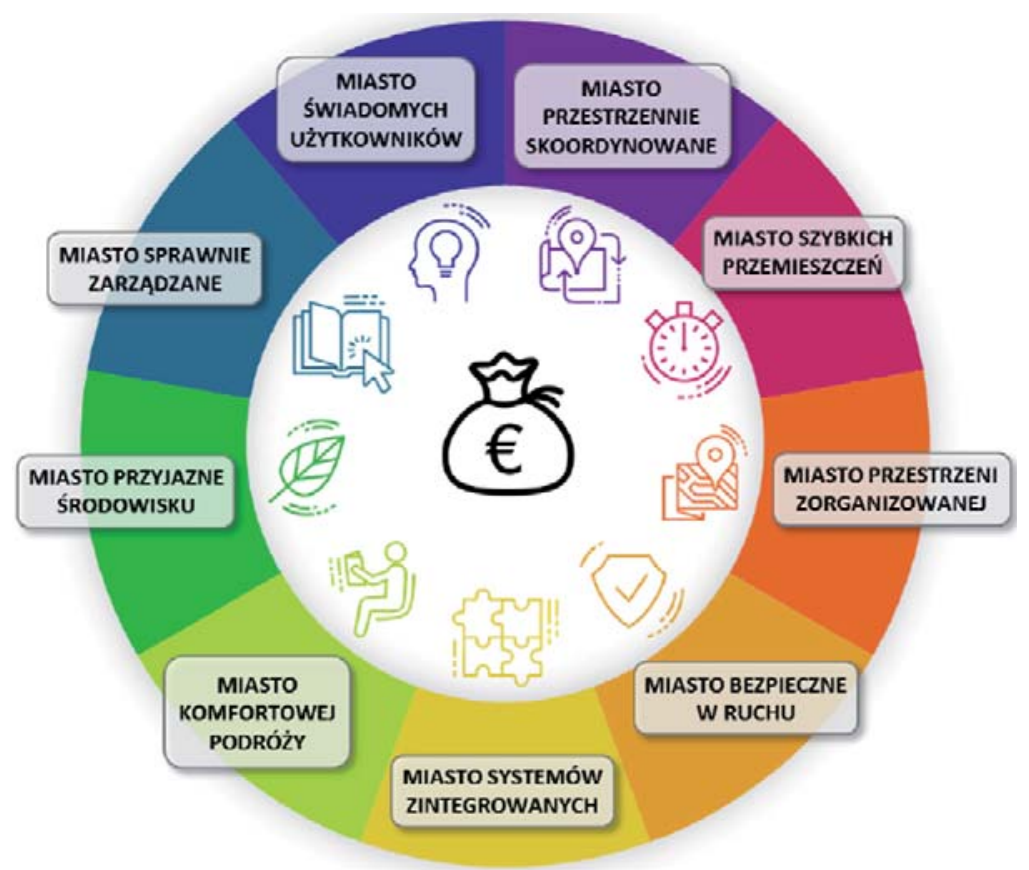

Rysunek 4. Wrocław - miasto zrównoważone zgodnie z Planem Zrównoważonej Mobilności Miejskiej we Wrocławiu

Figure 4. Wrocław - city balanced in accordance with the Sustainable Urban Mobility Plan in Wrocław

Źródło: [Plan Zrównoważonej..., 2019]. 
liczbie przemieszczeń, z 40\% w 2020 roku do 30\% w 2028 roku. Dokument nakreśla dziewięć różnych obszarów, realizujących razem docelową wizję miasta. Obszary te przedstawiono na rysunku 4.

\section{Podsumowanie i wnioski}

Przedstawione przykłady pokazują, że polskie miasta poważnie podchodzą do tematu zrównoważonej mobilności. Sektor prywatny dostrzega duży potencjał w usługach realizowanych w ramach współdzielenia, czego efektem jest gwałtowny rozwój serwisów usługowych w największych polskich miastach. Równolegle swoje prace związane z reorganizacją transportu w mieście (i miejskiej przestrzeni) prowadzą także samorządy. To niezwykle ważne, że koncepcja zrównoważonego (trwałego) rozwoju, realizowana pod hasłem także strategii smart city jest realizowana wspólnie, przez sektor prywatny i publiczny. Ten pierwszy dysponuje często znacznie większym kapitałem, drugi z kolei ma możliwość aktywnego kreowania lokalnej polityki (strategii) transportowej.

Porównując rozwiązania zastosowane w analizowanych miastach, należy zauważyć, że zasadniczo polityka wszystkich tych miast jest podobna. W proponowanych systemach rowerów miejskich czy car sharingu dostrzec można liczne analogie - pod względem zasad działania, czy wysokości ponoszonych przez użytkowników opłat. Część operatorów funkcjonuje równolegle w kilku miastach, co pozwala unifikować ofertę, a jednocześnie korzystać z efektu skali.

Niezależnie od tego, czy są to projekty realizowane z wykorzystaniem budżetów samorządów, czy firm prywatnych, służą one zmniejszaniu ruchu samochodów indywidualnych i poprawie efektywności wykorzystania miejskiej przestrzeni, wpisują się zatem w koncepcję zrównoważonej mobilności miejskiej, opisywanej na łamach publikacji krajowych i zagranicznych.

Celem autora była analiza dostępności rozwiązań z zakresu zrównoważonej logistyki miejskiej w największych polskich miastach. Należy zauważyć, że koncepcje zrównoważonej mobilności miejskiej są obszarem ulegającym ciągłym przeobrażeniom. Szybki rozwój systemów rowerów miejskich czy car sharingu stał się faktem. Należy zatem mieć na uwadze, że nowoczesne koncepcje logistyki miejskiej stanowią niezwykle cenny obszar badań i dają potencjał do prowadzenia interesujących badań w przyszłości.

\section{Literatura}

ALL, 2019: Kraków. Carsharing Kracar zostanie uruchomiony wtedy, gdy będą stacje ładowania, [źródło elektroniczne] https:/elektrowoz.pl/transport/krakow-carsharing-kracar-zostanie-uruchomiony-wtedy-gdy-beda-stacje-ladowania/ [dostęp: 02.05.2019].

Bączkowski R., 2017: Ekologiczne współdzielenie, [źródło elektroniczne] http://www.poznan.pl/ mim/info/news/ekologiczne-wspoldzielenie,112299.html [dostęp: 30.04.2019].

Berlińska E., Choma J., 2018: Implikacja innowacyjnych aplikacji mobilnych usprawniających przepływ osób w miastach na wdrażanie koncepcji zrównoważonego transportu oraz koncepcji SmartCity, Transport Miejski i Regionalny 1, 30-35. 
Bojba D., Kiciński M., Merkisz-Guranowska A., 2018: Ocena potencjału miejskiej zrównoważonej dystrybucji towarów na przykładzie miasta Poznania, Prace Naukowe Politechniki Warszawskiej, Transport 120, 29-38.

Carpooling czyli razem jeździmy samochodem, 2017, Zarząd Dróg Miasta Krakowa, [źródło elektroniczne] http://zikit.krakow.pl/strona_glowna/215102,artykul,carpooling_czyli_ razem_jezdzimy_samochodem.html [dostęp: 30.04.2019].

Dąbrowski T., 2017: Nowoczesne usługi logistyczne jako wyzwanie logistyki społecznej, Gospodarka w praktyce i teorii 1, Instytut Ekonomii, Uniwersytet Łódzki, Łódź, 17-26. DOI: 10.18778/1429-3730.46.02.

Deckert C., 2018: Sustainable Logistics: A Framework for Green Logistics and City Logistics, [w:] H. Lu, R. Schmidpeter, N. Capaldi, L. Zu (red.), Building New Bridges Between Business and Society. CSR, Sustainability, Ethics \& Governance. Springer, Cham. DOI: 10.1007/978-3-319-63561-3_4.

Gawełek L., Góral-Gawełek E., Fierek Sz., Pluta G., 2018: Priorytety w ruchu dla środków transportu zbiorowego oraz rowerów na przykładzie bus-pasa na ulicy Garbary w Poznaniu, Prace Naukowe Politechniki Warszawskiej, Transport 120, 111-121.

http://www.ztp.krakow.pl/rowery-towarowe/ [dostęp: 02.05.2019].

https://blinkee.city/pl\#cennik [dostęp: 30.04.2019].

https://stat.gov.pl/statystyka-regionalna/rankingi-statystyczne/miasta-najwieksze-pod-wzgledemliczby-ludnosci/ [dostęp: 01.05.2019]

https://takeanddrive.eu/map.html [dostęp: 02.05.2019].

https://wavelo.pl/ [dostęp: 30.04.2019].

https://wavelo.pl/wavelo-presspack.zip [dostęp: 30.04.2019].

Kiba-Janiak M., Witkowski J., 2014: Modelowanie logistyki miejskiej, PWE, Warszawa.

Korneć R., 2018: System transportu miejskiego wobec zrównoważonego rozwoju, [w:] J. Słodczyk (red.), Studia Miejskie 30, 71-84. DOI: 10.25167/sm2018.030.05

Kot S., 2013: Wpływ ekologicznego systemu transport miejskiego na jakość życia w polskich miastach na przykładzie inicjatywy Civitas, [w:] J. Słodczyk (red.), Studia Miejskie 10, $47-55$.

Kraków. Pierwsza w Polsce akcja dzielenia się samochodami, 2016, naszemiasto.pl, [źródło elektroniczne] http://krakow.naszemiasto.pl/artykul/krakow-pierwsza-w-polsce-akcja-dzielenia-sie-samochodami,3904928,artgal,t,id,tm.html [dostęp: 02.05.2019].

Miasto rozwija system car sharingu, 2018, Magiczny Kraków, [źródło elektroniczne] http://krakow.pl/aktualnosci/224277,29,komunikat,miasto_rozwija_system_car_sharingu.html [dostęp: 02.05.2019].

Ogórek P., 2017: Kraków. Więcej rowerów miejskich na zimę, [źródło elektroniczne] http://krakow. naszemiasto.pl/artykul/krakow-wiecej-rowerow-miejskich-na-zime,4335637,art,t,id,tm. html [dostęp: 30.04.2019].

Plan Zrównoważonej Mobilności Miejskiej dla Wrocławia, 2019, Biura Zrównoważonej Mobilności, Trako Projekty Transportowe, Wrocław, [źródło elektroniczne] http://bip.um.wroc.pl/attachments/download/68494 [dostęp: 02.05.2019].

Poznań: Firma Lime wprowadziła nowy cennik. Więcej zapłacimy za hulajnogi, 2019, naszemiasto.pl, [źródło elktroniczne] http://poznan.naszemiasto.pl/artykul/poznan-firmalime-wprowadzila-nowy-cennik-wiecej-zaplacimy,5017296,artgal,t,id,tm.html [dostęp; 30.04.2019].

Poznański Rower Miejski, Zarząd Transportu Miejskiego Poznań, [źródło elektroniczne] https:// www.ztm.poznan.pl/pl/komunikacja/rowery/ [dostęp: 30.04.2019]. 
Quak H., Tavasszy L., 2011: Customized Solutions for Sustainable City Logistics: The Viability of Urban Freight Consolidation Centres, [w:] J. van Nunen, P. Huijbregts, P. Rietveld (red.), Transitions Towards Sustainable Mobility, Springer-Verlag Berlin Heidelberg. DOI: $10.1007 / 978-3-642-21192-8 \_12$

Renault ZOE w naszych barwach!, 2019, Miejska Wypożyczalnia Samochodów Elektrycznych VOZILLA, [źródło elektroniczne] https://www.vozilla.pl/news/article/3115 [dostęp: 02.05.2019].

Rok Vozilli w pigułce, 2018, Miejska Wypożyczalnia Samochodów Elektrycznych VOZILLA, [źródło elektroniczne] https://www.vozilla.pl/news/article/2646 [dostęp: 02.05.2019]

Szołtysek J., 2016: Logistyka miasta, PWE, Warszawa.

Szymczak M., Ekonomia „na żądanie” i jej wpływ na logistykę miasta, [w:] J. Słodczyk (red.), Studia Miejskie 30, 25-38. DOI: 10.25167/sm2018.030.02

Taniguchi E., 2015: City Logistics for Sustainable and Liveable Cities, [w:] B. Fahimnia, M. Bell, D. Hensher, J. Sarkis (red.), Green Logistics and Transportation. Greening of Industry Networks Studies 4. Springer, Cham.

Trzy miesiące CityBee w Polsce, czyli BIG Carsharing w liczbach, 2019, CityBee Polska, [źródło elektroniczne] https://www.citybee.pl/pl/aktualnosci/trzy-miesiace-citybee-w-polsceczyli-big-carsharing-w-liczbach [dostęp: 02.05.2019].

Tundys B., 2013: Logistyka miejska. Teoria i praktyka, wyd. 2, Difin, Warszawa.

Umowy na system publicznego roweru miejskiego podpisane. Operatorem będzie NB Poznań Spółka z o.o., Zarząd Transportu Miejskiego Poznań, 2018, [źródło elektroniczne] https:// www.ztm.poznan.pl/pl/aktualnosci/umowy-na-system-publicznego-roweru-miejskiegopodpisane-operatorem-bedzie-nb-poznan-spolka-z-o-o [dostęp: 30.04.2019].

Wrocławski Rower Miejski 2019, 2019b, [źródło elektroniczne] https://wroclawskirower.pl/wroclawski-rower-miejski-2019/ [dostęp: 02.05.2019].

Wrocławski Rower Miejski bez przerwy przez cały rok, 2019a, [źródło elektroniczne] https:// wroclawskirower.pl/wroclawski-rower-miejski-bez-przerwy-przez-caly-rok/ [dostęp: 02.05.2019].

Wyszomirski O., 2017: Zrównoważony rozwój transportu w miastach a jakość życia, Transport miejski i regionalny $12,27-32$.

Adres do korespondencji:

dr Marcin Jurczak

(https://orcid.org/0000-0002-0828-308X)

Uniwersytet Ekonomiczny w Poznaniu

Katedra Logistyki i Transportu

ul. Niepodległości 10, 61-875 Poznań

e-mail: marcin.jurczak@ue.poznan.pl 



\title{
Ekonomika i Organizacja Logistyki \\ 4 (2), 2019, 29-39
}

DOI: 10.22630/EIOL.2019.4.2.12

\author{
Dorota Klepacka-Sulima ${ }^{1}$, Bogdan Klepacki ${ }^{2}$ \\ ${ }^{1}$ Nadbużańska Szkoła Wyższa w Siemiatyczach \\ ${ }^{2}$ Szkoła Główna Gospodarstwa Wiejskiego w Warszawie
}

\section{Stan infrastruktury drogowej województw o najniższym poziomie rozwoju w Polsce \\ The state of road infrastructure of voivodships with the lowest development level in Poland}

\begin{abstract}
Synopsis. Celem opracowania była prezentacja stanu i tendencji zmian infrastruktury drogowej w najsłabiej rozwiniętej części kraju, to znaczy Polski Wschodniej oraz bezpośrednim jej sąsiedztwa. Rozpoznano stanu dróg różnych grup, od utwardzonych do dróg szybkiego ruchu i autostrad. Wykazano, że stanu infrastruktury w badanych województwach znacznie odbiegał od średnich wartości dla całego kraju. W badanych latach (2002-2017) miał jednak miejsce postęp, zwłaszcza w województwie świętokrzyski i podkarpackim. Relatywnie najmniejsze postępy zanotowano w województwie warmińsko-mazurskim. Stwierdzono dodatnią korelację między stanem nasycenia województw drogami i poziomem ich rozwoju gospodarczego. Inwestycje w budowę dróg mogą więc być czynnikiem pobudzającym rozwój biedniejszych regionów.
\end{abstract}

Slowa kluczowe: infrastruktura drogowa, drogi, autostrady, PKB

\begin{abstract}
The aim of the study was to present the state and trends of road infrastructure changes in the least developed part of the country, i.e. in Eastern Poland and its immediate vicinity. The road conditions of various groups were identified, from paved roads to highways and motorways. It was shown that the condition of infrastructure in the analyzed voivodships differed significantly from the average values for the whole country. In the analyzed years (2002-2017), however, progress was made, especially in the Świętokrzyskie and Podkarpackie voivodships. The smallest progress has been recorded in the Warmian-Masurian voivodeship. There was a positive correlation between the state of voivodship saturation with roads and the level of their economic development. Investments in road construction can therefore be a factor stimulating the development of poorer regions.
\end{abstract}

Key words: road infrastructure, local roads, highways, GNP 


\section{Wstęp}

Jednym z ważniejszych celów działania Unii Europejskiej jest wyrównywanie poziomu rozwoju poszczególnych państw i regionów. Jest to jednak możliwe tylko w przypadku aktywizacji terenów rozwojowo opóźnionych, co wymaga poniesienia wielu inwestycji w kapitał ludzki oraz rzeczowy. Jednym z warunków zachęcających do przemieszczania ludzi oraz ich aktywności gospodarczej jest istnienie, a także poprawa sytuacji w zakresie infrastruktury.

Samo słowo infrastruktura ma źródłosłów łaciński i pochodzi od słów: infra (to co znajduje się poniżej) i structura (układ wzajemnych powiązań, zależności) [Mirowski 1996]. Infrastrukturę definiuje się obecnie jako „zespół podstawowych urządzeń i instytucji usługowych, niezbędnych do należytego funkcjonowania społeczeństwa i produkcyjnych działów gospodarki" [Słownik języka polskiego 2002]. Warunkuje ona rozwój gospodarczy regionów i kraju: bez nowoczesnej infrastruktury nie ma szans na wzrost gospodarczy. Istnieje tu współzależność: wyższy wzrost społeczno-gospodarczy wymaga lepszego zaplecza infrastrukturalnego [Ratajczak 2000].

Pod względem rzeczowym infrastrukturę dzieli się na gospodarczą (techniczną, np. transport i łączność, gospodarka wodna i kanalizacyjna, energetyka i gospodarka odpadami) oraz społeczną (edukacja, ochrona zdrowia, kultura i rekreacja itp.) [Kocur-Bera 2011].

Infrastruktura transportowa jest częścią składową infrastruktury gospodarczej i obejmuje drogi wszystkich gałęzi oraz punkty transportowe (dworce, bocznice, lotniska, porty itp.), a także urządzenia pomocnicze. Do jej najważniejszych zadań zaliczamy zaspokojenie potrzeb społeczeństwa oraz gospodarki, realizację zadań polityki transportowej, a także kształtowanie dziedzictwa przeszłości (obiekty infrastruktury mogą być pomnikami architektury) [Szymonik 2013].

Infrastruktura transportu może być także określana jako taka, której składniki są wykorzystywane w czasie ruchu i postoju poprzez użytkowników środków transportu. Obejmuje ona drogi oraz punkty transportowe wyposażone w środki i przedmioty niezbędne do jej funkcjonowania [Gołembska 2010].

$\mathrm{Z}$ punktu widzenia umiejscowienia $\mathrm{w}$ procesie rozwoju, zdaniem autorów opracowania, można wyróżnić infrastrukturę o charakterze pierwotnym (niezbędnych do pojawienia się innych jej rodzajów) oraz wtórnym (rozwijanych w trakcie działania zakładów gospodarczych oraz zamieszkiwania ludzi). Do tych drugich zaliczamy obiekty infrastruktury technicznej takie jak wodociągi, kanalizacja oraz społecznej, czyli np. szkoły czy szpitale. Aby jednak mogło rozwijać się życie społeczno-gospodarcze niezbędna jest wcześniej infrastruktura pierwotna, transportowa, w tym zwłaszcza liniowa (ciągła). Bez niej nie nastąpi żadna ekspansja kapitału i ludzi na mniej rozwinięte tereny. Potwierdzają to fakty historyczne: początkowo czynnikiem osadnictwa, a następnie rozwoju rejonów było bowiem istnienie (powstawanie) dróg komunikacji i transportu. W dawnych wiekach to były początkowo rzeki i szlaki morskie, następnie lądowe trakty handlowe, drogi żelazne, a współcześnie wszystkie dostępne rodzaje dróg lądowych, wodnych i powietrznych. W warunkach terenów lądowych, zwłaszcza słabiej rozwiniętych gospodarczo, szczególne znaczenie dla ich rozwoju ma 
transport drogowy i kolejowy, a przy relatywnie słabym stanie tego ostatniego - infrastruktura drogowa ${ }^{1}$.

Celem badań było poznanie stanu infrastruktury drogowej najsłabiej rozwiniętych województw położonych we wschodnim pasie pogranicznym i z nimi sąsiadujących, a także określenie tendencji zmian w tym zakresie. Ponadto, celem badań było określenie współzmienności między stanem infrastruktury drogowej a poziomem produktu krajowego brutto (PKB) na mieszkańca w województwie. Zakres czasowy badań empirycznych W większości analiz obejmuje lata 2002-2017, choć w niektórych analizach obszar badawczy, według potrzeb, został skrócony. W badaniach wykorzystano dostępne dane statystyki masowej GUS, zwłaszcza Banku Danych Lokalnych oraz literaturę przedmiotu.

\section{Ekonomiczna sytuacja województw Polski Wschodniej}

Polska jest krajem o dość dużych różnicach w poziomie rozwoju. Zróżnicowanie to można mierzyć z zastosowaniem wielu mniej lub bardziej skomplikowanych metod, zarówno jednoczynnikowych (z uwzględnieniem jednej cechy, takich jak poziom dochodów, spożycia określonych produktów, stanu służby zdrowia, szkolnictwa i wielu innych), jak i syntetycznych, uwzględniających w jednym mierniku wiele charakterystyk regionu. Jako najprostszą miarę, a także najszerzej wykorzystywaną w praktyce, można uznać poziom produktu krajowego brutto w przeliczeniu na jednego mieszkańca. Sytuację w kraju w takim ujęciu zaprezentowano na rysunku 1.

Polska jest krajem o dość dużym zróżnicowaniu pod względem poziomu PKB na mieszkańca. W pewnym uproszczeniu można wskazać cztery grupy województw: mazowieckie, o zdecydowanie najwyższym poziomie i tempie rozwoju, województwa o dość wysokim poziomie, bliskim średniej krajowej (dolnośląskie, wielkopolskie, śląskie, pomorskie, małopolskie), o nieco niższym poziomie od wspomnianych (kujawsko-pomorskie, lubuskie, opolskie, zachodniopomorskie), a także uzyskujące najsłabsze wyniki położone na wschodzie kraju (lubelskie, podkarpackie, podlaskie, świętokrzyskie i warmińsko-mazurskie). Sytuacja taka ma źródła historyczne i nadal brak jest jednoznacznych opinii jak przyśpieszyć rozwój województw opóźnionych, i w jakim stopniu poprawie sytuacji mają pomóc inwestycje w infrastrukturę transportową.

Ogólnie można stwierdzić, że istnieje współzmienność między poziomem PKB na mieszkańca a wyposażeniem województwa w drogi. Poziom współczynników korelacji między tymi zmiennymi przedstawiono w tabeli 1 .

\footnotetext{
${ }^{1}$ Szerzej pojęcie i stan infrastruktury przedstawiono w opracowaniu Klepacki B., Koper M., 2017: Stan i kierunki rozwoju infrastruktury drogowej w Polsce. Zeszyty Naukowe SGGW w Warszawie, Ekonomika i Organizacja Logistyki 4, s. 5-19, a jej znaczenie dla bezpieczeństwa ruchu w opracowaniu Klepacki B., Koper M., 2018: Miejsce infrastruktury w ksztattowaniu bezpieczeństwa w ruchu drogowym. Zeszyty Naukowe SGGW w Warszawie, Ekonomika i Organizacja Logistyki 1, s. 39-49.
} 


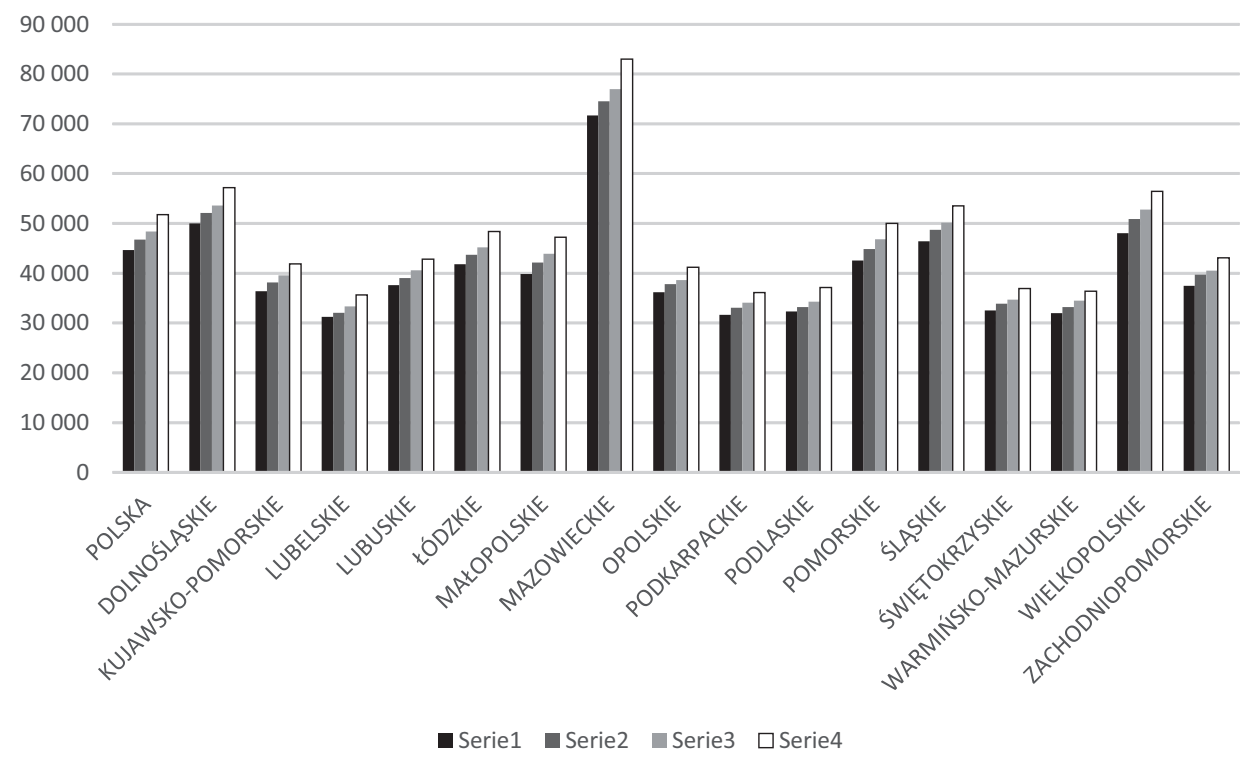

Rysunek 1. Poziom PKB na mieszkańca Polski z podziałem na województwa w latach 2014-2017 (PLN)

Figure 1. The level of GDP per capita of Poland with the division into voivodships in the years 2014-2017 (PLN)

Źródło: opracowanie własne na podstawie: [Produkt Krajowy..., 2019].

Tabela 1. Korelacja miedzy poziomem PKB na mieszkańca a stanem wybranych elementów infrastruktury drogowej na poziomie województw

Table 1. Correction between GDP per capita and infrastructure status

\begin{tabular}{|l|c|c|c|c|}
\hline \multirow{2}{*}{ Rodzaj drogi } & \multicolumn{3}{|c|}{$\begin{array}{r}\text { Współczynnik korelacji brutto miedzy PKB/mieszkańca a długością drogi } \\
\text { w województwach w latach na }\end{array}$} \\
\cline { 2 - 5 } & \multicolumn{2}{|c|}{$100 \mathrm{~km}^{2}$} & $2002-2016$ & 2016 \\
\cline { 2 - 5 } & $2002-2016$ & 2016 & $-0,2138$ & $-0,5921$ \\
\hline o nawierzchni twardej & 0,2830 & 0,2708 & $-0,1317$ & $-0,5666$ \\
\hline o nawierzchni ulepszonej & 0,3830 & 0,2843 & 0,3672 & $-0,0594$ \\
\hline ekspresowe i autostrady & 0,5100 & 0,2578 & & \\
\hline
\end{tabular}

Źródło: obliczenia własne na podstawie: [Produkt Krajowy, ...2019].

Istnieje dodatnia korelacja między stanem infrastruktury drogowe a poziomem PKB na osobę. Jest ona dodatnia w przypadku odniesienia stanu dróg do obszaru województwa, a ujemna w odniesieniu do liczby ludności. Jest to zrozumiałe, bowiem w obsza- 
rach wiejskich są duże odległości miedzy miejscowościami, a mało ludzi, w miastach natomiast jest odwrotnie. Ogólnie jednak, lepsze nasycenie drogami danego obszaru jest dodatnio skorelowane z poziomem jego rozwoju.

\section{Zmiany długości dróg w badanych województwach}

Podstawowymi miarami stanu infrastruktury drogowej jest długość dróg według ich rodzajów oraz stan techniczny. Ze względu na ograniczone miejsce do analizy skoncentrowano się na pierwszym mierniku, czyli długości dróg (rys.2).

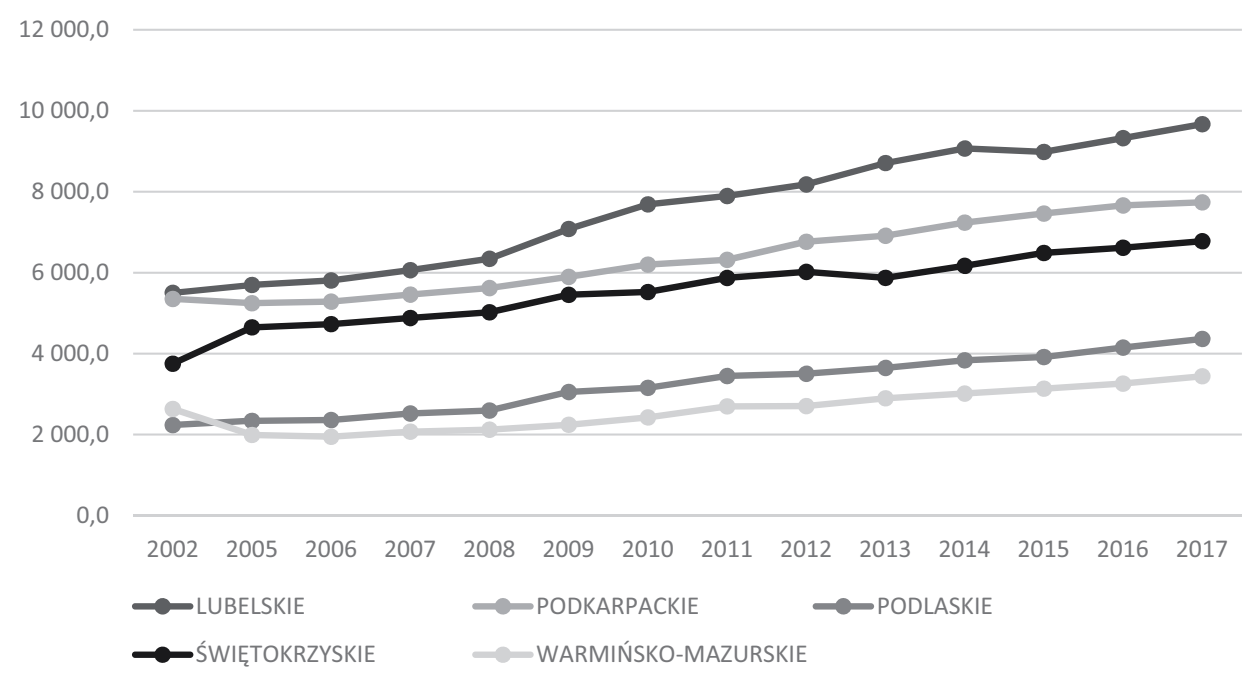

Rysunek 2. Długość dróg gminnych o nawierzchni twardej w badanych województwach $(\mathrm{km})$ Figure 2. The length of municipal roads with hard surface in the examined voivodships (km)

Spośród badanych województw najdłuższą siecią utwardzonych dróg gminnych dysponuje województwo lubelskie (około 9,7 tys. km w 2017 roku), a następnie podkarpackie i świętokrzyskie. Zdecydowanie mniej rozbudowana jest sieć tych dróg w województwach warmińsko-mazurskim (3,4 tys. km) i podlaskim (4,4 tys. km). Różna jednak była aktywność inwestycyjna w badanych województwach. W latach 2002-2017 najwyższą dynamiką przyrostu długości dróg charakteryzowały się województwa: podlaskie $(95,3 \%)$ i świętokrzyskie $(80,7 \%)$, a najniższą warmińsko-mazurskie $(30,7 \%)$.

Badane województwa są zróżnicowane pod względem powierzchni, stąd lepszą miarą nasycenia ich drogami jest przedstawienie długości dróg w przeliczeniu na jednostkę powierzchni (rys. 3).

W skali kraju w latach 2002-2017 gęstość dróg wzrosła o 19,7\%, a wśród badanych województw tempo zmian było na ogół nieco korzystniejsze, bowiem wskaźnik ten dla województw świętokrzyskiego wyniósł $28,8 \%$, lubelskiego $24,6 \%$, podlaskiego $23,7 \%$, a podkarpackiego $19,8 \%$. Jedynie w województwie warmińsko-mazurskim sytuacja była znacznie gorsza aniżeli przeciętnie w kraju, bowiem gęstość dróg wzrosła zaledwie 


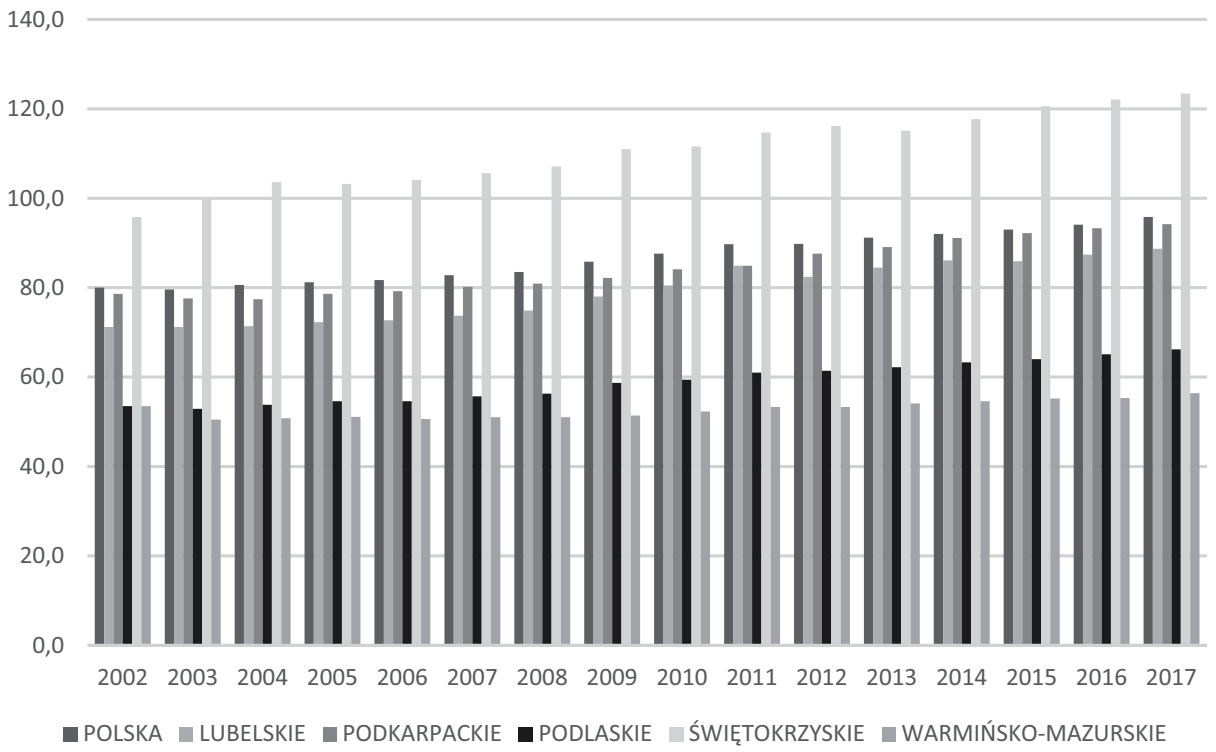

Rysunek 3. Długość dróg o nawierzchni twardej w badanych województwach w km na $100 \mathrm{~km}^{2}$ Figure 3. The length of hard surface roads in the examined voivodships in $\mathrm{km}$ per $100 \mathrm{~km}^{2}$ Źródło: opracowanie własne na podstawie: [Transport i łączność..., 2019].

140,0

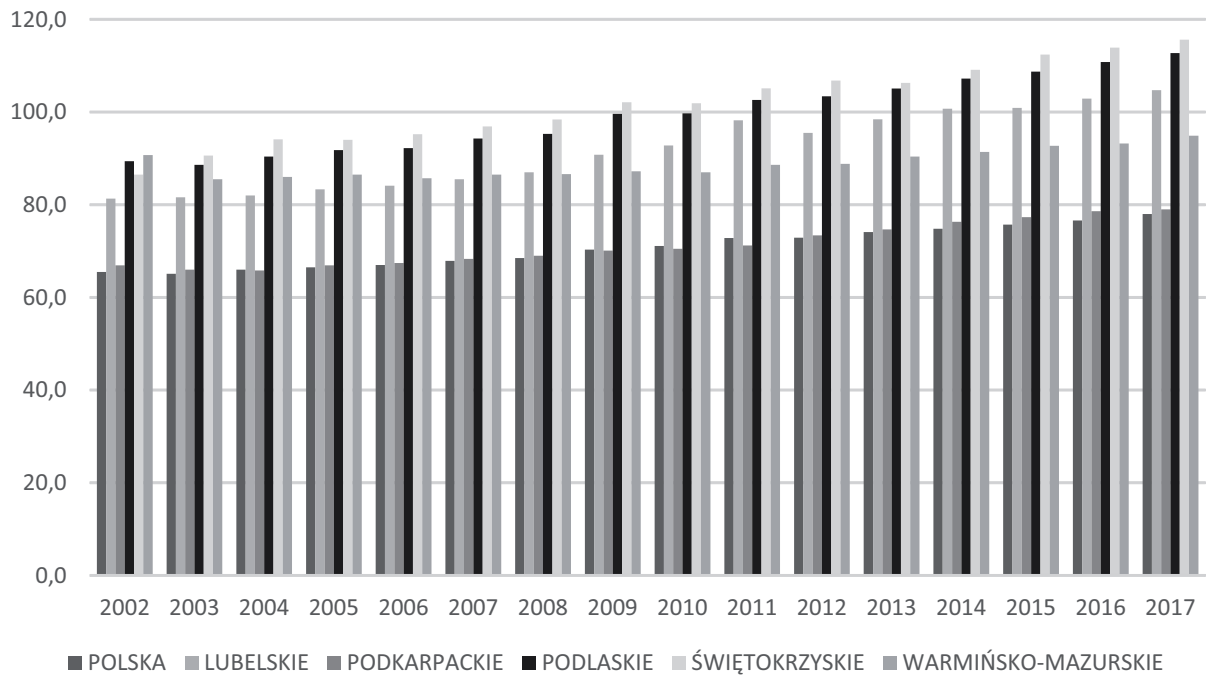

Rysunek 4. Długość dróg o nawierzchni twardej w badanych województwach w km na 10 tys. osób

Figure 4. The length of roads with hard surface in in the examined voivodships in km per 10 thous. people

Źródło: opracowanie własne na podstawie: [Transport i łączność..., 2019]. 
o 5,4\%, a więc sytuacja w tym terenie uległa relatywnemu pogorszeniu. W 2017 roku badany wskaźnik dla tego województwa wynosił tylko 56,4 km wobec 123,4 km w województwie świętokrzyskim i 95,8 km w kraju.

Innym miernikiem jest długość dróg w odniesieniu do liczby mieszkańców. Zmiany w tym zakresie przedstawiono na rysunku 4.

W Polsce w latach 2002-2017 gęstość o twardej nawierzchni w przeliczeniu na 10 tys. mieszkańców wzrosła o 19,1\%. W badanych województwach podobnie jak przy poprzednim mierniku tempo zmian było korzystniejsze, bowiem dla województwa świętokrzyskiego wyniosło $33,6 \%$, lubelskiego $28,8 \%$, podlaskiego $26,1 \%$. Gorzej było w województwie podkarpackim (18,1\%), a bardzo źle w województwie warmińsko-mazurskim, gdzie zanotowano wzrost długości tych dróg jedynie o 4,6\%. W ostatnim roku badań długość dróg na 1 tys. mieszkańców w województwie podkarpackim wynosiła 79,0 km, a w województwie warmińsko-mazurskim 94,9 km wobec 115,6 km w województwie świętokrzyskim i 78,0 km w Polsce.

Na rysunku 5 zaprezentowano długość dróg gminnych i powiatowych w odniesieniu do jednostki obszaru, czyli na $100 \mathrm{~km}^{2}$.

W skali kraju w latach 2002-2017 gęstość dróg gminnych i powiatowych wzrosła o 21,3\%, a wśród badanych województw tempo zmian było na ogół nieco korzystniejsze, bowiem wskaźnik ten dla województw lubelskiego wzrósł o $27,3 \%$, podlaskiego $25,2 \%$, świętokrzyskiego 23,1\%, a podkarpackiego 22,1\%. W województwie warmińsko-mazurskim sytuacja była znacznie gorsza aniżeli przeciętnie w kraju, bowiem gęstość dróg wzrosła zaledwie o 13,7\%, a więc sytuacja w tym terenie uległa relatywnemu pogorsze-

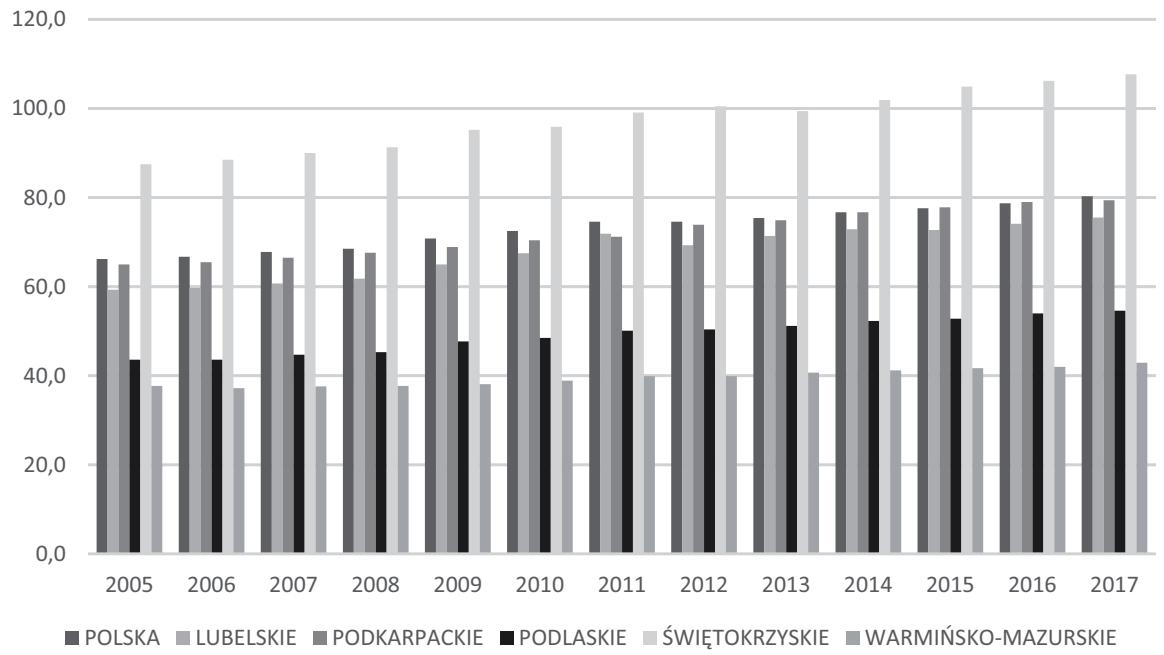

Rysunek 5. Długość dróg gminnych i powiatowych o nawierzchni twardej w badanych województwach w $\mathrm{km}$ na $100 \mathrm{~km}^{2}$

Figure 5. The length of commune and poviat roads with hard surface in the examined voivodships in $\mathrm{km}$ per $100 \mathrm{~km}^{2}$

Źródło: opracowanie własne na podstawie: [Transport i łączność..., 2019]. 


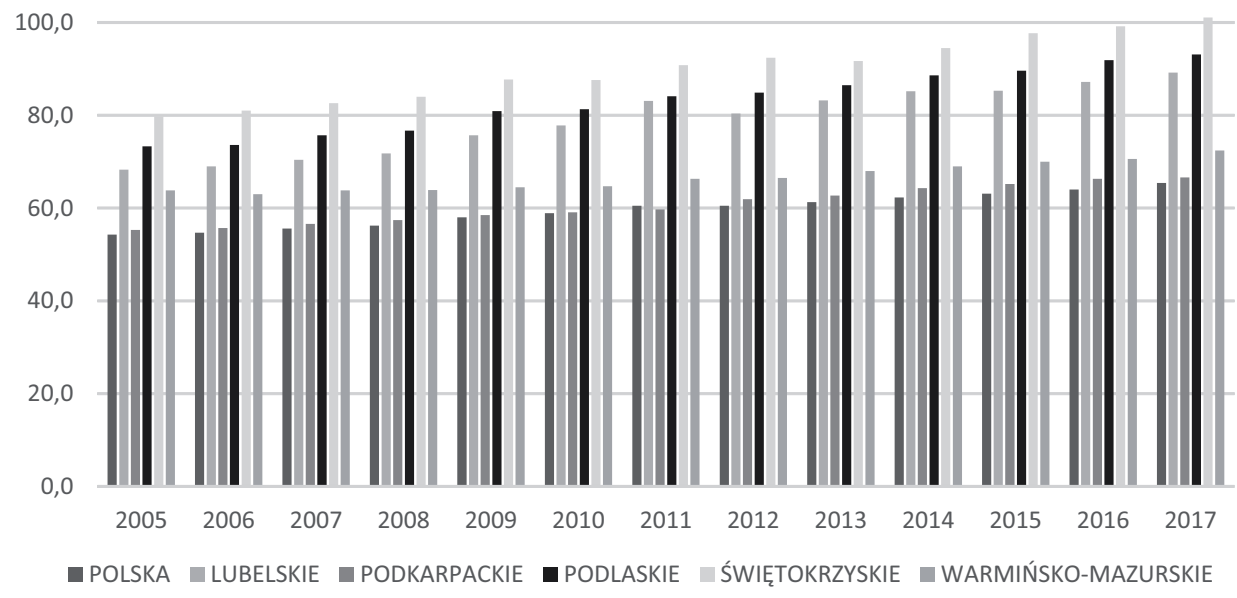

Rysunek 6. Długość dróg gminnych i powiatowych o nawierzchni twardej w badanych województwach w km na 10 tys. osób

Figure 6 . The length of commune and poviat roads with hard surface in the examined voivodships in $\mathrm{km}$ per 10,000 people

Źródło: opracowanie własne na podstawie: [Transport i łączność..., 2019].

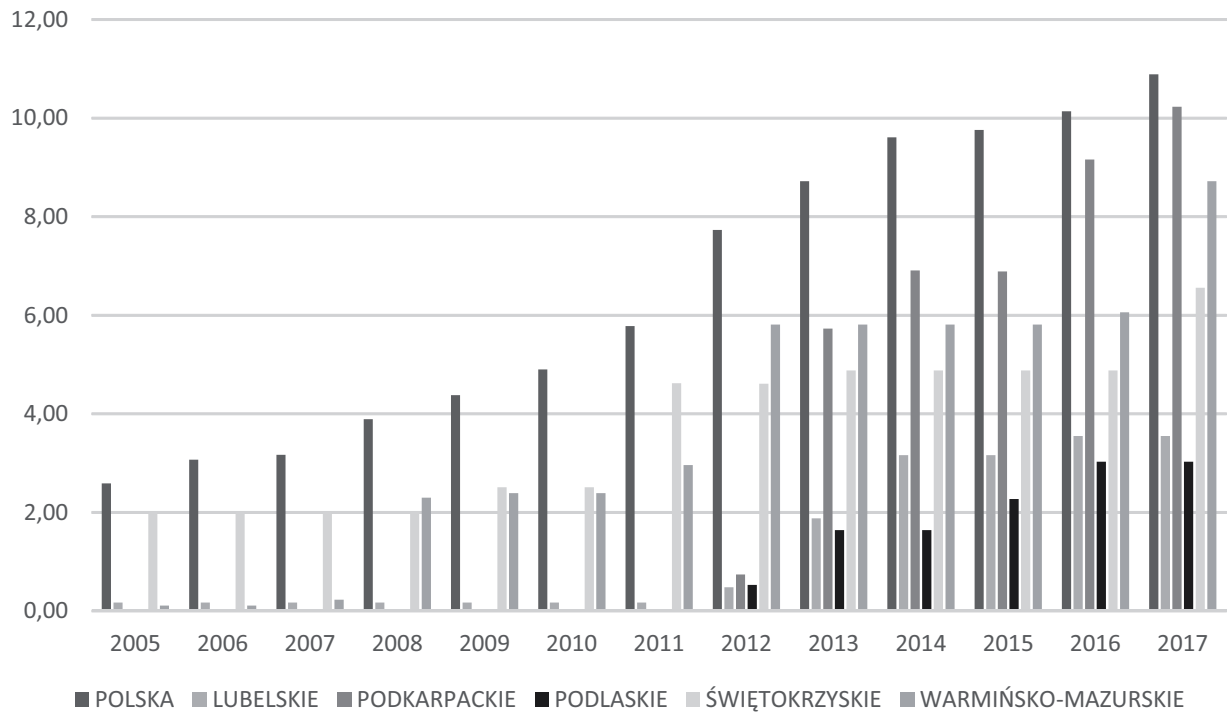

Rysunek 7. Długość dróg ekspresowych i autostrad w badanych województwach w km na 1 tys. km² Figure 7. Length of expressways and highways in the examined voivodships in km per 1 tys. $\mathrm{km}^{2}$ Źródło: Źródło: opracowanie własne na podstawie: [Transport i łączność..., 2019]. 
niu. W 2017 roku badany wskaźnik dla tego województwa wynosił tylko 42,9 km wobec 107,7 km w województwie świętokrzyskim i 80,3 w kraju.

Na rysunku 6 przedstawiono długość dróg gminnych i powiatowych w odniesieniu do liczby mieszkańców.

W Polsce w latach 2002-2017 gęstość dróg gminnych i powiatowych w przeliczeniu na 1 tys. mieszkańców wzrosła o 20,4\%. W badanych województwach, podobnie jak przy poprzednim mierniku tempo zmian było korzystniejsze, bowiem dla województwa lubelskiego wyniosło $30,6 \%$, podlaskiego $27,0 \%$, świętokrzyskiego $26,7 \%$, a podkarpackiego $20,4 \%$. Ponownie, w województwie warmińsko-mazurskim tempo poprawy sytuacji było najsłabsze $(13,5 \%)$. W ostatnim roku badań długość dróg na 1 tys. mieszkańców w województwie podkarpackim wynosiła $66,6 \mathrm{~km}$, a w województwie warmińsko-mazurskim 72,4 km wobec 101,1 km w województwie świętokrzyskim i 65,4 w Polsce.

Współcześnie najbardziej zaawansowane rozwiązania w przypadku infrastruktury drogowej to drogi szybkiego ruchu i autostrady. Stan tych dróg oraz tendencje zmian przedstawiono na rysunku 7.

W pierwszym roku badań (2005) w dwóch województwach (podlaskim i podkarpackim) wcale nie było dróg szybkiego ruchu, w pozostałych były to wielkości minimalne, a w skali kraju na 1 tys. $\mathrm{km}^{2}$ przypadało ich zaledwie 2,59 km (w świętokrzyskim $2,02 \mathrm{~km}$, lubelskim 0,17 km i warmińsko-mazurskim 0,11 km). Do 2017 roku sytuacja uległa znacznej poprawie, zarówno w skali kraju $\left(10,89 \mathrm{~km}\right.$ na 1 tys. $\mathrm{km}^{2}$, wzrost 4,2-krotny), jak i w niektórych województwach, zwłaszcza podkarpackim (do $10,2 \mathrm{~km})$, warmińsko-mazurskim $(8,7 \mathrm{~km})$ i świętokrzyskim $(6,6 \mathrm{~km})$. Najmniej było dróg szybkiego ruchu w województwach podlaskim $(3,0 \mathrm{~km})$ i lubelskim $(3,5 \mathrm{~km})$. $\mathrm{Z}$ analizowanych województw jedynie podkarpackie, dzięki autostradzie A4, zbliżyło się do poziomu średniej krajowej. W nie najgorszej sytuacji jest też województwo warmińsko-mazurskie, pozostałe natomiast województwa już znacznie odbiegają in minus.

\section{Wnioski}

1. Stan infrastruktury drogowej w badanych, najuboższych województwach w Polsce w stosunku do ich obszaru jest mniej korzystny od przeciętnego w kraju. Ale nawet wśród nich występuje znaczne zróżnicowanie: najkorzystniejsza, nawet lepsza od średniej krajowej pod względem nasycenia drogami utwardzonymi jest sytuacja w województwie świętokrzyskim, podobna do przeciętnych w województwach lubelskim i podkarpackim, natomiast najgorsza w północno-wschodniej Polsce (województwa podlaskie i warmińsko-mazurskie). To ostatnie województwo w badanych latach nie niwelowało różnic, lecz wręcz przeciwnie - traciło dystans do Polski i innych województw.

2. W relacji do liczby ludności korzystniejszą od średniej sytuację w zakresie infrastruktury drogowej miały województwa: podlaskie, lubelskie (małe zaludnienie) i świętokrzyskie (centralne położenie w kraju). Najbardziej odbiegał od średniej stan autostrad 
i dróg szybkiego ruchu, w które słabo były wyposażone zwłaszcza województwa podlaskie i lubelskie.

3. Województwa Polski Wschodniej miały znacznie niższy poziom rozwoju gospodarczego mierzonym wielkością PKB na mieszkańca od przeciętnego w kraju. Jednocześnie tempo jego wzrostu było zbliżone we wszystkich województwach, można mówić nawet o stagnacji relacji miedzy regionami. W decyzjach gospodarczych nie wykorzystywano instrumentu rozwoju infrastruktury drogowej do aktywizacji obszarów poza aglomeracjami, stąd poziom rozwoju poszczególnych rejonów kraju nie wykazywał jak dotychczas tendencji do wyrównywania się.

4. Z badań korelacyjnych wynika, że lepsze nasycenie drogami wykazuje współzmienność z wyższym poziomem PKB na mieszkańca. Oznacza to, że inwestycje w rozwój infrastruktury drogowej mogą być wykorzystywane w poprawie szans rozwojowych terenów mniej rozwiniętych.

\section{Bibliografia}

Gołembska E (red.), 2010: Kompendium wiedzy o logistyce, Wydawnictwo Naukowe PWN, Warszawa.

Klepacki B., Koper M., 2017: Stan i kierunki rozwoju infrastruktury drogowej w Polsce, Zeszyty Naukowe SGGW w Warszawie, Ekonomika i Organizacja Logistyki 4.

Klepacki B., Koper M., 2018: Miejsce infrastruktury w kształtowaniu bezpieczeństwa w ruchu drogowym, Zeszyty Naukowe SGGW w Warszawie, Ekonomika i Organizacja Logistyki 1.

Kocur-Bera K., 2011: Rozwój infrastruktury na przykładzie wybranych gmin wiejskich, Infrastruktura i Ekologia Terenów Wiejskich, PAN Oddział w Krakowie, 1.

Mirowski W., 1996: Studia nad infrastrukturą wsi polskiej. Wyposażenie obszarów w infrastrukturę społeczną, t. 3, PAN Instytut Rozwoju Wsi i Rolnictwa, Warszawa.

Produkt Krajowy Brutto. Rachunki Regionalne. Bank Danych Lokalnych, [źródło elektroniczne] https://bdl.stat.gov.p1/BDL/dane/podgrup/temat: [dostęp 24.04.2019].

Ratajczak M., 2000: Infrastruktura a wzrost i rozwój gospodarczy, Ruch prawniczy, ekonomiczny i socjologiczny 4.

Słownik języka polskiego, 2002, Wydawnictwo Naukowe PWN, Warszawa.

Szymonik A., 2013: Ekonomika transportu dla potrzeb logistyka(i). Teoria i Praktyka, Difin, Warszawa.

Transport i łączność. Rachunki Regionalne. Bank Danych Lokalnych, [źródło elektroniczne] https://bdl.stat.gov.pl/BDL/dane/podgrup/temat: [dostęp 24.04.2019]. 
Stan infrastruktury drogowej województw...

Adres do korespondencji:

dr Dorota Klepacka-Sulima

(https://orcid.org/0000-0003-2026-6992)

Nadbużańska Szkoła Wyższa im. Marka J. Karpia w Siemiatyczach

ul. T. Kościuszki 43, 17-300 Siemiatycze

prof. dr hab. Bogdan Klepacki

(https://orcid.org/0000-0003-3483-7530)

Szkoła Główna Gospodarstwa Wiejskiego w Warszawie

Wydział Nauk Ekonomicznych

Katedra Logistyki

ul. Nowoursynowska 166, 02-787 Warszawa

e-mail: bogdan_klepacki@sggw.pl 



\title{
Ekonomika i Organizacja Logistyki \\ 4 (2), 2019, 41-53
}

DOI: 10.22630/EIOL.2019.4.2.13

\section{Dorota Krupnik}

Wojskowa Akademia Techniczna w Warszawie

\section{Bezpieczeństwo zarządzania lańcuchem dostaw biomasy Safety security of biomass supply chain management}

\begin{abstract}
Synopsis. Celem niniejszego artykułu jest zaprezentowanie możliwości wykorzystania biomasy do celów energetycznych oraz analiza bezpiecznego zarządzania procesami logistycznymi w łańcuchu dostaw biomasy. Czynnikami, które należy wziąc pod uwagę w bezpiecznym zarządzaniu łańcuchem dostaw biomasy, są m.in.: różnorodność biomasy (objętość, wilgotność, rozproszony charakter), odległości od źródeł pozyskania surowców, lokalizacja miejsc produkcji energii. W celu uniknięcia przemieszczania dużych mas biomasy na znaczne odległości zasadne jest tworzenie lokalnych rynków biomasy oraz systemów logistycznych minimalizujących koszty pozyskiwania, transportu i składowania biomasy. Dużą nadzieję można wiązać z certyfikowanymi systemami zapewniania jakości biomasy. Wpłynie to w znacznym stopniu na bezpieczeństwo dostaw tak różnorodnego w swoim właściwościach surowca.
\end{abstract}

Slowa kluczowe: proces, system, proces logistyczny, biomasa, łańcuch dostaw, zarządzanie łańcuchem dostaw

\begin{abstract}
The aim of this article is to present the possibilities of using biomass for energy purposes and analysis of safe management of logistics processes in the biomass supply chain. Factors that should be taken into account in the safe management of the biomass supply chain include: biomass diversity (volume, humidity, diffuse nature), distances from sources of raw materials, location of energy production sites. In order to avoid moving large biomass masses over long distances, it is reasonable to create local biomass markets and logistic systems that minimize the costs of biomass acquisition, transport and storage. A lot of hope can be associated with certified biomass quality assurance systems. This will have a significant impact on the security of supply of raw materials so diverse in its properties.
\end{abstract}

Key words: process, system, logistics process, biomass, supply chain, supply chain management

\section{Wstęp}

Polityka energetyczna państwa wskazuje na potrzebę stosowania niskoemisyjnych źródeł energii we wszystkich dziedzinach życia. W 2011 roku rozpoczął się proces tworzenia wspólnego rynku energii w UE. W związku z tym wszedł w życie tzw. trzeci pakiet energe- 
tyczny, obejmujący dyrektywy rynkowe, rozporządzenia, m.in. rozporządzenie ustanawiające Agencję ds. Współpracy Organów Regulacji Energetyki [Dyrektywa 2009/72/WE].

Jako jeden ze sposobów monitorowania realizacji polityki energetycznej Polski do 2030 roku wskazano wskaźniki monitorowania. Przewidziano 7 wskaźników, pozwalających ocenić realizację celów polityki energetycznej państwa, ujętych w art. 13 ustawy prawo energetyczne. Jeden ze wskaźników dotyczy udziału energii ze źródeł odnawialnych, w tym biomasy, w finalnym zużyciu energii [Polityka energetyczna ..., 2009, s. 28-29].

Polityka UE w dziedzinie środowiska naturalnego określona w traktacie akcesyjnym, a uwzględniona m.in. w dyrektywie 2009/28/WE dała podstawę, iż Polska zadeklarowała wzrost udziału odnawialnych źródeł energii w produkcji energii elektrycznej do $15 \% \mathrm{w}$ 2020 roku [Polityka energetyczna ..., 2009, s. 28-29, Energy Law..., 2016]. Z analizy dokumentów wynika, iż przygotowywane regulacje prawne w Polsce powinny ukierunkować rynek w taki sposób, aby można wywiązać się ze zobowiązań [Wnioski z analiz..., 2015, s. 1-17]. Brak strategii państwa i niestabilne przepisy w kolejnych latach, mimo zmian w legislacji [Ustawa o odnawialnych..., 2015] mogą temu zagrozić. Z danych statystycznych [Energia ze źródeł..., 2017] wynika, iż udział energii ze źródeł odnawialnych w końcowym zużyciu energii ogółem w 2016 roku był na poziomie $11 \%$.

Mając na uwadze systemowe podejście do wykorzystania biomasy, Urząd Regulacji Energetyki (URE) przeprowadził prace nad podstawami funkcjonowania systemu uwierzytelniania biomasy, czyli Krajowym Systemem Uwierzytelniania Biomasy.

Celem URE w tym zakresie stało się [The National..., 2013]:

- usprawnienie i uproszczenie procesu wydawania świadectw pochodzenia - korzystania $\mathrm{z}$ mechanizmu wsparcia;

- uwiarygodnienie pochodzenia i jakości biomasy;

- wyeliminowanie potencjalnych nieprawidłowości na rynku biomasy.

W literaturze z 2014 roku czytamy o powszechnym stosowaniu w Polsce technologii współspalania biomasy z węglem [Szyszlak-Bargłowicz i in., 2014, s. 354-358]. Współspalanie biomasy z węglem ma swoje ograniczenia i stosowanie większych ilości biomasy wymaga uprzedniej modernizacji istniejących kotłów lub nowych technologii. Możliwe byłoby wykorzystanie biomasy w lokalnym ciepłownictwie, jednak bez systemowego wsparcia dla tego typu instytucji jest to utrudnione. Rynek oferuje dla elektrowni budowę nowych lub modernizację już istniejących mocy wytwórczych wykorzystujących biomasę, np. wysokociśnieniowych oraz wysokotemperaturowych. Bardzo ciekawą koncepcją jest np. system BioPower Recyc z elastycznym kotłem CFB dla szerokiego zakresu paliw: biomasa łącznie z odpadami (RDF) i osadami z oczyszczalni ścieków. Wiele nowych projektów jest możliwe do realizacji z Programu Operacyjnego Infrastruktura i Środowisko, NFoŚiGW w Warszawie oraz regionalnych programów operacyjnych. Przykładami takich projektów jest nowoczesna ciepłownia w Lęborku lub Elektrociepłownia Kalisz-Piwonice.

Wykorzystanie biomasy do celów np. energetycznych wpływa korzystnie na:

- zagospodarowanie odpadów,

- wyższą redukcję emisji $\mathrm{CO}_{2}$,

- wyższą efektywność energetyczną.

Energia pozyskiwana ze źródeł odnawialnych w Polsce w 2017 roku pochodziła w przeważającym stopniu z biopaliw stałych (67,9\%), tj. 260052 TJ [Energia ze źródeł..., 2017]. 
Prognoza pozyskania biomasy leśnej w 2021 roku z lasów państwowych szacuje się na $36,9 \mathrm{mln}^{3}$, z lasów prywatnych ok. 4,9 mln $\mathrm{m}^{3}$ netto [Mirowski i in. 2018, s. 27]. Roczna produkcja słomy w polskich gospodarstwach rolnych wynosi ponad $34 \mathrm{Mg}$. Od kilku lat zwiększają się nadwyżki słomy i obecnie szacuje się je na 10-11 Mg ton rocznie [Hryniewicz i Grzybek 2017]. Jest to ogromne wyzwanie logistyczne w łańcuchu dostaw tego surowca.

\section{Cel i metodyka badań}

Celem niniejszego artykułu jest zaprezentowanie możliwości wykorzystania biomasy do celów energetycznych oraz analiza bezpiecznego zarządzania procesami logistycznymi w łańcuchu dostaw biomasy. Problem badawczy wiąże się z zasadniczym pytaniem: w jakim stopniu dotychczasowe potrzeby i możliwości pozyskiwania odnawialnych źródeł energii w Polsce mogą wpłynąć na bezpieczeństwo zarządzania łańcuchem dostaw biomasy? Autorka poszukuje odpowiedzi na pytania dotyczące zarządzania i doskonalenia łańcuchów dostaw biomasy rolnej i leśnej w odniesieniu do możliwości wykorzystywania zasobów odnawialnych.

$\mathrm{W}$ badaniach zastosowano teoretyczne i empiryczne metody badawcze. Z teoretycznego punktu widzenia, do osiągnięcia celu i rozwiązania problemów badawczych posłużono się metodą studiów literatury polskiej i zagranicznej, analizą opisową oraz analizą porównawczą w celu przetwarzania danych. Metody teoretyczne pozwoliły na analityczne zbadanie, uporządkowanie i opisanie materiału badawczego. W dalszej części zastosowano metody empiryczne w postaci obserwacji naukowej w celu uzyskania informacji o badanych faktach, zjawiskach i elementach składowych bezpiecznego zarządzania procesami logistycznymi w łańcuchu dostaw biomasy.

Do prezentacji wyników badań wykorzystano metody: opisową, tabelaryczną i graficzną.

\section{Wyniki badań}

\section{Biomasa jako źródło energii}

W związku z koniecznością realizacji założeń dyrektywy 2009/28/WE, udział energii ze źródeł odnawialnych w finalnym zużyciu energii systematycznie wzrasta. W tabeli 1 przedstawiono udział energii ze źródeł odnawialnych w Polsce. Progresja w latach 2010-2017 oraz planowanie strategiczne na kolejne lata dają podstawę na osiągnięcie celu 15\% w 2020 roku. Istotnym elementem w realizacji polityki rozwoju odnawialnych źródeł energii (OZE) było przyjęcie przez Radę Ministrów w dniu 7 grudnia 2010 roku Krajowego planu działań (KPD) w zakresie energii ze źródeł odnawialnych. Dokument ten przedstawił działania dochodzenia do 15\% udziału OZE w wytwarzaniu energii finalnej w Polsce do 2020 roku z utrzymaniem progresji w kolejnych latach. Takie same założenia znajdziemy w Polityce energetycznej Polski do 2030 roku. 
Tabela 1. Udział energii ze źródeł odnawialnych w finalnym zużyciu energii w wybranych latach w Polsce (\%)

Table 1. Share of energy from renewable sources in final energy consumption in selected years in Poland (\%)

\begin{tabular}{|l|c|c|c|c|c|c|}
\hline Rok & $\begin{array}{c}2007 \\
\text { wartość bazowa }\end{array}$ & 2010 & 2012 & 2014 & 2020 & 2030 \\
\hline $\begin{array}{l}\text { Udział energii ze źródeł } \\
\text { odnawialnych w końcowym } \\
\text { zużyciu energii brutto }\end{array}$ & 7,7 & 9,4 & 11,04 & 11,45 & 15 & powyżej \\
\hline
\end{tabular}

Źródło: opracowanie na podstawie: [Polityka energetyczna..., 2015; GUS 2017].

Z biomasy jako surowca pozyskuje się energię pierwotną. Jest to energia zawarta w nośnikach pozyskiwanych bezpośrednio z zasobów naturalnych odnawialnych i nieodnawialnych. Przez pozyskanie należy rozumieć ilość energii uzyskaną z naturalnych zasobów [GUS 2017]. W energetyce jako biomasę traktuje się wszystkie rodzaje substancji organicznych pochodzenia roślinnego lub zwierzęcego nadające się do spalania. Wyróżnikiem jest możliwość zaliczenia konkretnego biopaliwa do tzw. zielonej energii o zerowej emisji $\mathrm{CO}_{2}$ [Szyszlak-Bargłowicz i in., 2014, s. 356].

W polskim prawie ustawa z 2006 roku o biopaliwach i biokomponentach ciekłych [Ustawa..., 2006] definiuje biomasę jako stałe lub ciekłe substancje pochodzenia roślinnego, lub zwierzęcego, które ulegają biodegradacji, pochodzące z produktów, odpadów i pozostałości z produkcji rolnej oraz leśnej, przemysłu przetwarzającego ich produkty, a także części pozostałych odpadów, które ulegają biodegradacji, a w szczególności surowce rolnicze.

Podstawowymi cechami biomasy są [Ściążko i in. 2007, s. 141-160]:

- niska wartość opałowa - waha się w granicach: $6 \mathrm{MJ} / \mathrm{kg}$ (odpady komunalne), 6-16 MJ/kg (zrębki drzewne, słoma), $18 \mathrm{MJ} / \mathrm{kg}$ (pelety),

- wysoka zawartość wilgoci w surowej biomasie (45-60\%),

- wysoka zawartość części lotnych (2,5-krotnie wyższa niż w węglu),

- mała zawartość popiołu w biomasie drzewnej $<1 \%$,

- niska zawartość azotu i siarki i duża zawartość związków alkalicznych oraz szczególnie w słomie chloru.

Według dyrektywy Parlamentu Europejskiego i Rady z 23 kwietnia 2009 roku [Dyrektywa..., 2009/28/WE] dotyczącej wspierania produkcji energii elektrycznej pochodzącej ze źródeł odnawialnych, „biomasa oznacza ulegającą biodegradacji część produktów, odpadów lub pozostałości pochodzenia biologicznego z rolnictwa (łącznie z substancjami roślinnymi i zwierzęcymi), leśnictwa i związanych działów przemysłu, w tym rybołówstwa i akwakultury, a także ulegającą biodegradacji część odpadów przemysłowych i miejskich". Polska ze względu na warunki klimatyczne może uprawiać trzy grupy roślin na cele energetyczne: drzewa i krzewy - wierzba, trawy (np. miskant), byliny (np. ślazowiec) [Mirowski i in., 2018, s. 25]. W przypadku biomasy na cele energetyczne największe znaczenie w perspektywie 2020 roku mogą mieć uprawy energetyczne, m.in. ze względu na podejmowane próby wykluczenia biomasy drzewnej z definicji odnawialnego źródła energii, który wpłynął do Trybunału Sprawiedliwości UE. 
Energia biomasy stanowi ok. 15\% światowego zużycia energii, przy czym w krajach rozwiniętych udział ten jest większy i wynosi aż 38\%. Przyjmuje się, że w procesie spalania biomasy bilans emisji $\mathrm{CO}_{2}$ jest zerowy, ponieważ tyle się go emituje do atmosfery, ile rośliny pobierają $\mathrm{w}$ procesie fotosyntezy, a przez to nie powodującym wzrostu $\mathrm{CO}_{2}$ w atmosferze [Postrzednik 2014, s. 573-578]. Zupełnie inne stanowisko w tej sprawie mają np. naukowcy z Chatham House, the Royal Institute of International Affairs, którzy w artykule „Woody Biomass for Power and Heat: Impacts on the Global Climate” przedstawiają, iż wycinanie drzew dla opału powoduje znacznie większą emisję $\mathrm{CO}_{2}$ netto w wyniku spalania tego drzewa w stosunku do emisji $\mathrm{CO}_{2} \mathrm{z}$ tej samej ilości energii $\mathrm{z}$ gazu, a nawet $\mathrm{z}$ węgla.

Wskaźniki masowe pozyskania suchej biomasy w Polsce kształtują się następująco [Gołębiowska 2013, s. 22-23]:

- tereny leśne ok. 3-5Mg/ha/rok,

- plantacje roślin energetycznych ok. 15-30 Mg/ha/rok.

Najistotniejszym składnikiem większości paliw stałych jest substancja palna, zbudowana z: C, H, O, N, S oraz tzw. balast, na który składają się: substancja mineralna (popiół) oraz wilgoć, której ilość (zawartość) może zmieniać się w zależności od czynników atmosferycznych. Wśród wymienionych składników paliwa najistotniejsza jest substancja palna mB (będąca w dominującej części substancją organiczną).

W przypadku wykorzystania biomasy pochodzenia nieleśnego (agro), która może być spalana w jednostkach współspalania biomasy i paliw konwencjonalnych o mocy przekraczającej 5 MW lub w układach hybrydowych i jednostkach biomasowych o mocy ponad $20 \mathrm{MW}$, należy udowodnić, że:

- pochodzi ona z upraw energetycznych lub,

- stanowi odpad lub pozostałość z produkcji rolnej, lub z przemysłu przetwarzającego produkty z produkcji rolnej lub,

- stanowi inny rodzaj odpadu ulegającego biodegradacji z wyłączeniem odpadów i pozostałości z produkcji leśnej, a także przemysłu przetwarzającego jej produkty.

Rynek biomasy w Polsce ma tendencje rozwijające się. W najbliższych latach prawdopodobny jest wzrost zapotrzebowania na biomasę w energetyce zawodowej i małej energetyce. Według szacunków Polska wykorzystuje jedynie ok. 7 \% swojego potencjału, jeśli

Tabela 2. Zasoby energii pierwotnej biomasy w Polsce z uwzględnieniem importu (ktoe)

Table 2. Energy resources of biomass in Poland including imports (ktoe)

\begin{tabular}{|l|c|c|c|c|}
\hline Rodzaj biomasy & $\begin{array}{c}\text { Całkowite } \\
2015\end{array}$ & $\begin{array}{c}\text { Import } \\
2015\end{array}$ & $\begin{array}{c}\text { Całkowite } \\
2020\end{array}$ & $\begin{array}{c}\text { Import } \\
2020\end{array}$ \\
\hline Produkty rolnicze & 2517 & 241 & 2902 & 389 \\
\hline Odpady produkcji rolnej & 2071 & - & 4411 & - \\
\hline Produkty leśne & 4122 & - & 4482 & - \\
\hline Odpady leśne & 2080 & 18,3 & 2292 & - \\
\hline bioodpady & 1031 & & 1391 & 15893,4 \\
\hline $\begin{array}{l}\text { Całkowite zasoby bio- } \\
\text { masy }\end{array}$ & \multicolumn{2}{|c|}{12079,0} & & \\
\hline
\end{tabular}

Źródło: [Krajowa mapa..., 2010; Krupnik i Mitkow 2017]. 
chodzi o biomasę wobec średniej 20\% w całej UE. W tabeli 2 zostały zestawione najnowsze dane dotyczące zasobów pierwotnej biomasy w Polsce z perspektywą do 2020 roku.

Polska dysponuje potencjałem biomasy ogółem, kształtującym się na poziomie 12 tys. TJ rocznie, który może być wykorzystany do celów energetycznych bez uszczerbku dla produkcji żywności i gospodarki leśnej.

Na rysunku 1 zostały przestawione tendencje rozwoju odnawialnych źródeł energii z uwzględnieniem biomasy stałej. Prognozuje się, iż zapotrzebowanie na biomasę będzie systematycznie rosło.

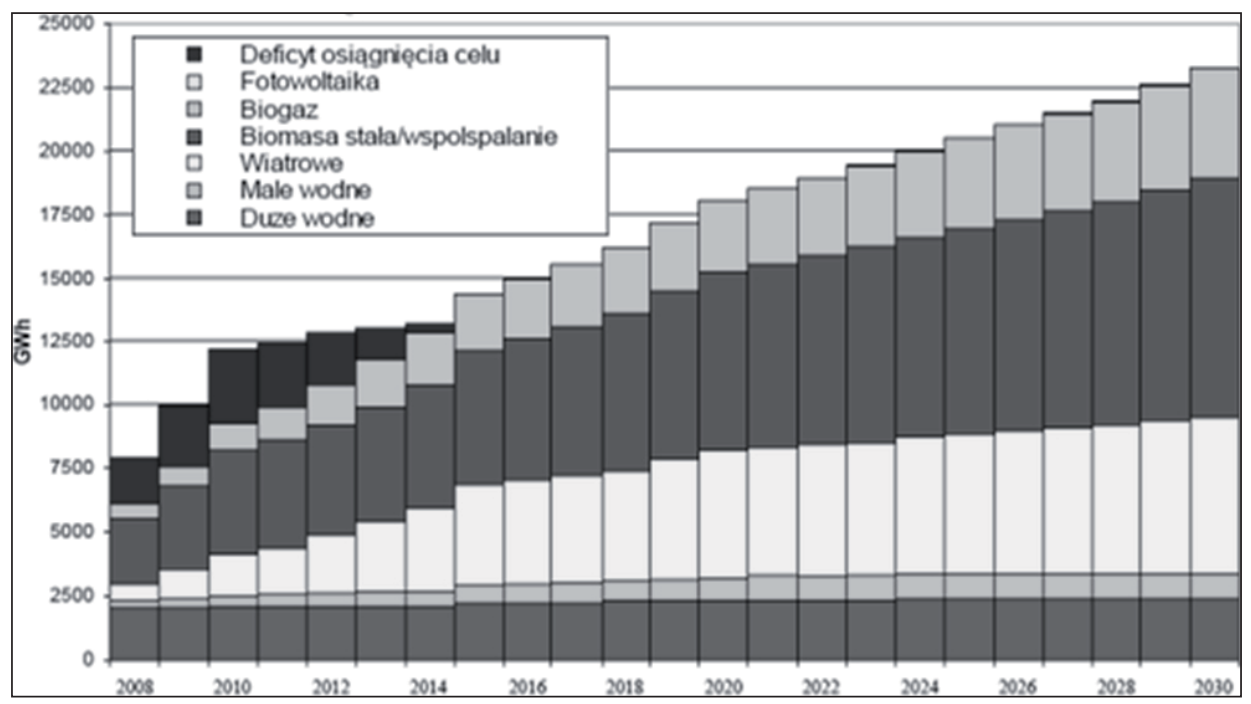

Rysunek 1. Potencjał OZE w Polsce z uwzględnieniem biomasy

Figure. 1. Potential of renewable energy sources in Poland including biomass

Źródło: [Bocian 2012, s. 9].

Ze względu na zainteresowanie wykorzystaniem biomasy do celów energetycznych istotna jest jej jakość. Urząd Regulacji Energii podejmuje działania w celu weryfikacji biomasy leśnej i rolniczej poprzez kontrolę pochodzenia dostaw, opierając się na wdrażanych $\mathrm{w}$ przedsiębiorstwach systemach zapewnienia jakości według normy PN-EN 15234-1:2011.

\section{Zarządzanie lańcuchem dostaw biomasy}

Biomasa może być używana na cele energetyczne w procesach bezpośredniego spalania lub współspalania biopaliw stałych (np. drewno, słoma, osady ściekowe), przetwarzana na paliwa ciekłe (np. estry oleju rzepakowego, alkohol) lub gazowana (np. biogaz rolniczy, biogaz z oczyszczalni ścieków, gaz wysypiskowy). Konwersja biomasy na nośniki energii może odbywać się metodami fizycznymi, chemicznymi, biochemicznymi. 
W zależności od tego, czy głównym produktem tego procesu jest gaz, paliwo płynne, czy paliwo stałe, mówimy odpowiednio o: spalaniu, współspalaniu zgazowaniu, pirolizie lub o procesach biochemicznych (rys. 2).

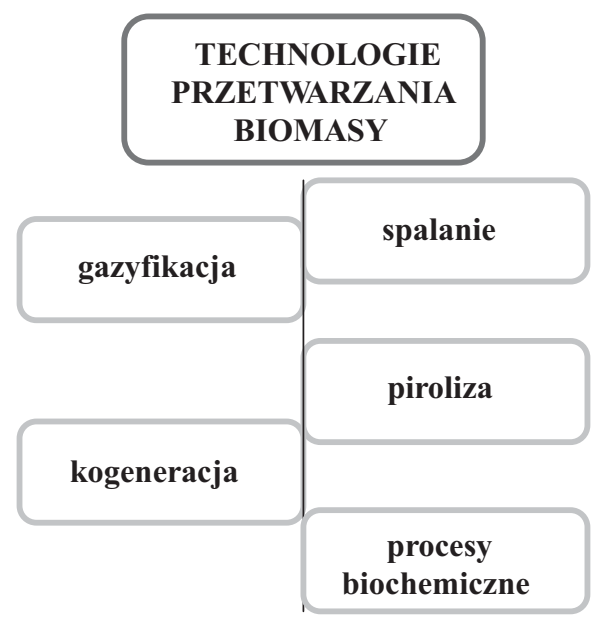

Rysunek 2. Zestawienie technologii przetwarzania i wykorzystania biomasy

Figure 2. List of biomass processing and utilization technologies

Źródło: opracowanie na podstawie: [Polityka energetyczna..., 2015].

Dla potrzeb klientów indywidualnych i małych instalacji grzewczych biomasa może być przetwarzana do postaci brykietów lub peletów. Brykiety z reguły nie zawierają żadnych substancji wiążących. Rośliny te rosną szybko i dają plony nawet przez 30 lat. Szacuje się, że z każdego ha można uzyskać od 25 do 45 t zrębków. Przed prasowaniem zrębki poddawane są suszeniu do zawartości wilgoci ok. 15\% [Szyszlak-Bargłowicz i in. 2014, s. 356].

Odpady drzewne prasowane są w ścisłe, niewielkie rolki, niezawierające żadnych dodatków ze względu na swe naturalne właściwości. Innym źródłem biomasy mogą być szybkorosnące topole lub wikliny. Pod względem energetycznym 2 t biomasy równoważne są od 1 do 1,5 t węgla kamiennego.

Stosowanie biomasy do celów energetycznych umożliwia spełnienie ostrych norm ochrony środowiska, szczególnie w zakresie emisji $\mathrm{CO}_{2}, \mathrm{SO}_{2}, \mathrm{NO}_{\mathrm{x}}$, pyłów, dioksyn, chlo$\mathrm{ru}$, metali ciężkich. Zgodnie z przepisami związanymi z ochroną środowiska mieszanka węgla $\mathrm{z}$ biomasą jest traktowana jak paliwo ekologiczne. Zastosowanie mieszanek węglowo-biomasowych ogranicza emisję $\mathrm{CO}_{2}$, do atmosfery. Bilans emisji jest zerowy, ponieważ podczas spalania do atmosfery oddawane jest tyle $\mathrm{CO}_{2}$, ile wcześniej rośliny pobrały z otoczenia. Ze względu na niską zawartość azotu w biomasie ograniczona jest emisja $\mathrm{NO}_{\mathrm{x}}$ do atmosfery w porównaniu ze spalaniem węgla [Szyszlak-Bargłowicz i in., 2014, s. 356].

Podstawowe sposoby wykorzystania biomasy w instalacjach energetycznych, realizowane są poprzez jej spalanie (jako paliwa podstawowego) lub współspalanie (z innym paliwem alternatywnym). Z danych z 2013 roku wynika, iż udział technologii współ- 
spalania lub spalania biomasy w elektrowniach, elektrociepłowniach węglowych jest największy ze wszystkich technologii OZE i wynosi ok. 40\%, w całkowitej sprzedaży energii ze źródeł odnawialnych [Gołębiowska 2013]. Cały czas prowadzi się badania nad nowymi i efektywniejszymi rozwiązaniami technologicznymi, które zastępują współspalanie, m.in. wspomniany wcześniej Program Operacyjny Infrastruktura i Środowisko, oś priorytetowa I Zmniejszenie emisyjności gospodarki.

Jaki jest cel logistyki ze względu na specyficzne wymagania biomasy jako surowca? Efektem finalnym działania procesów logistycznych jest zapewnienie stabilnej bazy surowcowej podmiotom zajmującym się wywarzeniem energii z biomasy. W wielu przypadkach pozyskanie biomasy jest utrudnione ze względu na jej rozproszony charakter. Z tych względów wymaga dużych nakładów na zbiór, transport, magazynowanie i przetwarzanie. Dlatego tak ważny jest sprawny system logistyczny wpływający na ograniczanie kosztów transportu i dalszego przetworzenia. Czynnikami, które należy uwzględnić w systemie logistycznym, są związane m.in. z [Osiak i Dwórznik 2016, s. 63]:

- rodzajem biomasy,

- cechami fizyczno-chemicznymi i mechanicznymi biomasy,

- dostępnością surowca,

- liczbą dostawców danego typu biomasy,

- możliwościami technicznymi transportu,

- możliwościami magazynowania,

- możliwościami obróbki wstępnej przed procesem konwersji,

- uwarunkowaniami ekonomicznymi, prawnymi, ochroną środowiska itp.

- lokalizacją miejsc produkcji energii.

W związku z prowadzonymi przez URE pracami nad Krajowym Systemem Uwierzytelniania Biomasy (KSUB) istotne stało się wypracowanie założeń będących podstawą do opracowania procedur jakościowych i kontroli pochodzenia dostaw biomasy. Na rysunku 3, w sposób ideowy, przedstawiono schemat systemu uwierzytelniania dla biomasy nieprzetworzonej i przetworzonej w całym łańcuchu dostaw.

Wykorzystanie biomasy wymaga podjęcia działań w całym łańcuchu dostaw obejmującego: pozyskanie surowca, produkcję, dystrybucję i wykorzystanie biomasy, w tym transport i magazynowanie. Przyjmując jako kryterium źródło do produkcji energii w technologii energii odnawialnej, wyróżniamy dwie grupy zarządzania w logistyce [Zarządzanie logistyczne..., 2014, s.13]:

- zarządzanie kompletnym łańcuchem dostaw (CSCM) z biomasą stałą i płynną jako źródłem energii,

- zarządzanie częściowym łańcuchem dostaw (PSCM) z energią słoneczną, wiatrem, geotermą, hydroenergią itd.

W tabeli 3 zostały zestawione elementy łańcucha dostaw obu grup.

Kompletny łańcuch dostaw (CSCM) obejmuje proces zaopatrzenia, czyli dostawy surowców i materiałów do produkcji energii i jej utrzymania, proces produkcji energii oraz proces dystrybucji energii. Z punktu widzenia procesów logistycznych ważne jest, aby surowiec był dostarczany w sposób ciągły. Z tego też względu zarządzanie odnosi się do wszystkich procesów i podmiotów łańcucha, które powinny być powiązane ze sobą.

Celem zarządzania łańcuchem dostaw jest zwiększenie wydajności przy równoczesnej redukcji kosztów magazynowych i operacyjnych oraz dostosowania produkcji 

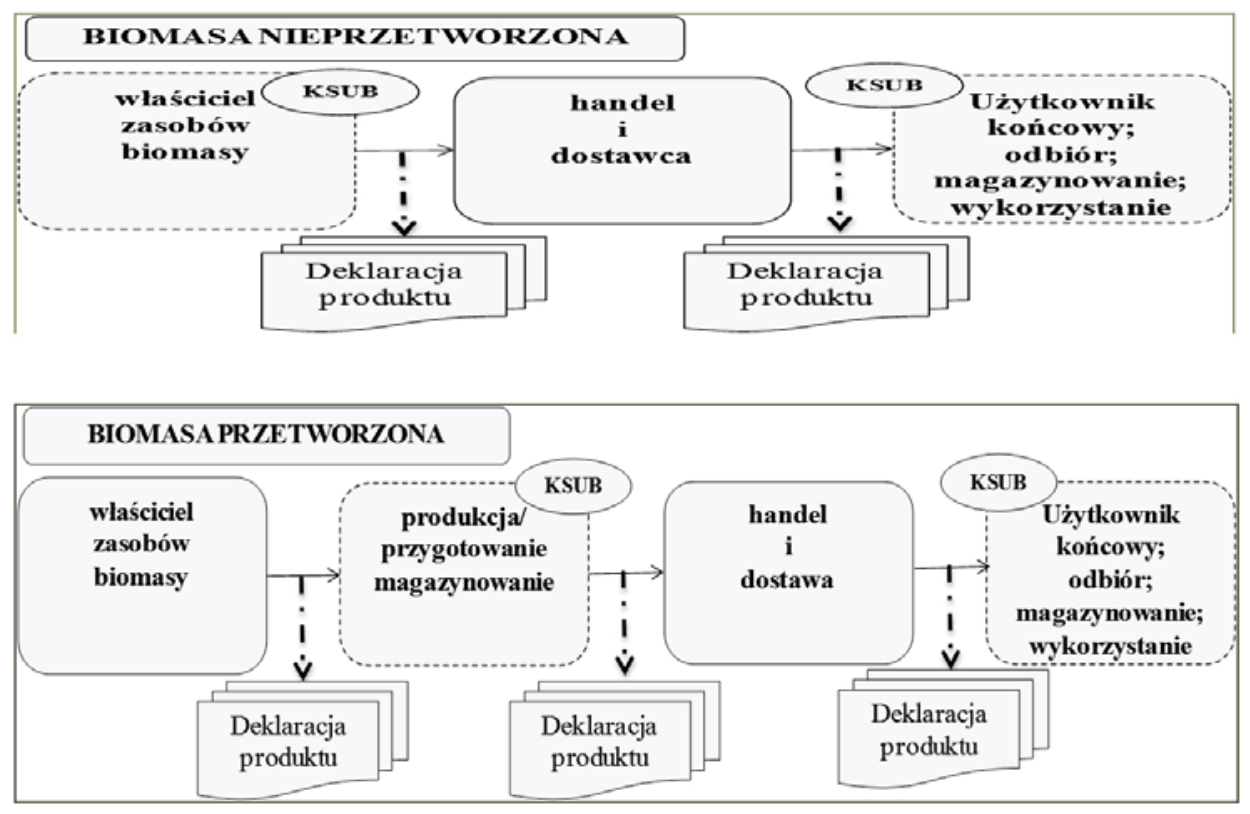

Rysunek. 3. Schemat systemu uwierzytelniania biomasy w łańcuchu dostaw Figure 3. Scheme of the biomass authentication system in the supply chain Źródło: opracowanie na podstawie: [URE 2013].

Tabela 3. Zestawienie elementów łańcucha dostaw w technologii OZE

Table 3. List of elements of the supply chain in the technology of renewable energy sources

\begin{tabular}{|l|c|c|}
\hline Etapy łańcucha dostaw & CSCM & PSCM \\
\hline Zaopatrzenie & tak & ograniczona \\
\hline Produkcja & tak & ograniczona \\
\hline Dystrybucja & tak & ograniczona \\
\hline Źródło energii & biomasa & słońce, wiatr, geoterma, inne \\
\hline
\end{tabular}

Źródło: opracowanie na podstawie: [Zarządzanie..., 2014, s.13; Krupnik 2016].

energii do potrzeb klientów. Zarządzanie obejmuje cztery główne etapy [Węcław-Solny 2012, s. 26]:

- dostawy (zarządzanie dostawami surowców, relacje z dostawcami, bazy dostawców),

- operacje (zarządzanie zapotrzebowaniem, zapasami, proces produkcji),

- logistyka (projektowanie sieci dostaw/dystrybucji, zarządzanie relacjami z klientami),

- integracja (zarządzanie ryzykiem, pomiarami, wydajnością, ochroną środowiska).

Mając na względzie kierunki rozwoju energetyki, w której zawarto promowanie energii ze źródeł odnawialnych, w tym biomasy, coraz większą uwagę zwraca się na systemy zapewnienia jakości biomasy. Polega to na wspieraniu procesu wdrażania norm jakości, które można ocenić na podstawie konkretnych wymagań, uwzględnionych w systemach certyfikacji. Niezależna weryfikacja powinna objąć cały łańcuch dostaw od producenta 


\section{Krupnik}

biomasy do dystrybutora końcowego. W każdym z nich uwzględnia się parametry jakościowe i określa krytyczne punkty kontrolne (KPK). Są to miejsca w procesie lub między poszczególnymi procesami, podczas których można ocenić poszczególne właściwości i najskuteczniej wdrożyć działania na rzecz poprawy jakości. Uwzględniane są w całym łańcuchu dostaw:

- przygotowanie pola,

- sadzenie/sianie,

- uprawy agrotechniczne,

- zbiór (pozyskiwanie z pola/lasu),

- przeładunek i transportu do miejsca, gdzie można zastosować transport drogowy,

- przechowywanie (sezonowa dostępność) - punkty składowania w gospodarstwach rolnym, w lesie, na wydzielonych miejscach lub na terenie obiektów energetycznych,

- przetwarzanie biomasy w celu poprawy jego efektywności obsługi i gęstości do transportu,

Tabela. 4. Przykładowe zestawienie etapów procesu peletyzacji

Table 4. Example combination of stages of the pelletization proces

\begin{tabular}{|c|c|c|c|}
\hline Etapy procesu & \multicolumn{2}{|c|}{$\begin{array}{c}\text { Czynniki wpływające na jakość surowca, } \\
\text { działania i ustawienia urządzeń }\end{array}$} & $\begin{array}{l}\text { Krytyczne punkty } \\
\text { kontroli }\end{array}$ \\
\hline \multicolumn{4}{|c|}{ I etap na polu } \\
\hline Zbieranie słomy & kombajn & zanieczyszczenia & podczas zbioru \\
\hline Belowanie & balociarka & $\begin{array}{l}\text { trwałość balotów, } \\
\text { wilgotność }\end{array}$ & po sprasowaniu \\
\hline $\begin{array}{l}\text { Magazynowanie posortowanej } \\
\text { słomy na polu (magazyn główny) }\end{array}$ & warunki przechowywania & $\begin{array}{l}\text { wilgotność, gęstość } \\
\text { energetyczna }\end{array}$ & podczas sortowania \\
\hline Transport do zakładu & środek transportu & $\begin{array}{c}\text { Wilgotność, utrata } \\
\text { surowca }\end{array}$ & podczas załadunku \\
\hline \multicolumn{4}{|c|}{ II etap w przedsiębiorstwie } \\
\hline Odbiór surowca & \multicolumn{2}{|c|}{ zanieczyszczenia, wilgotność } & dostawa surowca \\
\hline $\begin{array}{l}\text { Przechowywanie w miejscu } \\
\text { produkcji }\end{array}$ & warunki przechowywania & $\begin{array}{c}\text { zanieczyszczenia, } \\
\text { wilgotność }\end{array}$ & przed obróbką \\
\hline Obróbka: mieszanie i rozdrabnianie & sieczkarka, dobór surowca & $\begin{array}{l}\text { trwałość, gęstość, } \\
\text { wytrzymałość }\end{array}$ & w trakcie mieszania \\
\hline Suszenie & $\begin{array}{c}\text { suszarka } \\
\text { (temperatura i czas) }\end{array}$ & $\begin{array}{c}\text { wilgotność, } \\
\text { trwałość, gęstość, } \\
\text { wytrzymałość }\end{array}$ & - \\
\hline Mielenie & młyn i sita & $\begin{array}{c}\text { jednakowy rozmiar } \\
\text { surowca }\end{array}$ & po mieleniu \\
\hline Kondycjonowanie & kondycjoner & $\begin{array}{l}\text { wydajność prasy, } \\
\text { wytrzymałość }\end{array}$ & $\begin{array}{c}\text { po } \\
\text { kondycjonowaniu }\end{array}$ \\
\hline Paletyzacja & rolki i matryce & $\begin{array}{c}\text { wytrzymałość, } \\
\text { wydajność }\end{array}$ & $\begin{array}{c}\text { w trakcie } \\
\text { paletyzacji }\end{array}$ \\
\hline Chłodzenie & chłodnia & - & podczas chłodzenia \\
\hline Przesiewanie & sita & ilość drobnej frakcji & po przesianiu \\
\hline Przechowywanie & warunki przechowywania & $\begin{array}{c}\text { temperatura, } \\
\text { wilgotność }\end{array}$ & $\begin{array}{c}\text { podczas } \\
\text { przechowywania }\end{array}$ \\
\hline Załadunek & środki transportu & $\begin{array}{l}\text { zanieczyszczenia, } \\
\text { ilość drobnej frakcji }\end{array}$ & podczas załadunku \\
\hline
\end{tabular}

Źródło: opracowanie własne na podstawie [Grecka 2013]. 
- transport i wykorzystanie paliwa w obiekcie energetycznym.

Szczegółowe zestawienie etapów procesu bezpiecznego zarządzania łańcuchem dostaw biomasy od etapu pola, poprzez produkcję pelet, aż do użytkownika został przedstawiony na przykładzie paletyzacji w tabeli 4 . Na poszczególnych etapach zostały uwzględnione czynniki wpływające na właściwości końcowego wyrobu na dwóch etapach - na polu i przedsiębiorstwie produkcyjnym. Etap pierwszy poprzedzony jest podpisaniem umowy z rolnikami przed okresem żniw.

Przetwarzanie biomasy ma na celu poprawę jej efektywności poprzez zwiększenie gęstości w procesach belowania, brykietowania czy peletowania oraz poprawę jakości paliwa. Większość rodzajów biomasy charakteryzuje się sezonowością, rozproszeniem, dlatego wymaga składowania, w celu zapewnienia ciągłości dostaw. Procesy magazynowania powinny zapewnić sprawny rozładunek oraz bezpieczeństwo przechowywania biomasy w warunkach nadzorowanych.

\section{Podsumowanie i wnioski}

Dokonując analizy literatury w obszarze zastosowania biomasy do celów energetycznych w postaci peletyzacji, należy stwierdzić, iż programy wykorzystania odnawialnych źródeł energii, nie zawsze opierają na jednorodnych i spójnych danych.

Czynnikami, które należy wziąć pod uwagę w bezpiecznym zarządzaniu łańcuchem dostaw biomasy, są m.in.:

- różnorodność biomasy (objętość, wilgotność, rozproszony charakter),

- odległości od źródeł pozyskania surowców,

- lokalizacja miejsc produkcji energii.

Biomasa jest w Polsce perspektywicznym źródłem zielonej energii. Konieczne jest jednak systemowe wsparcie i podejście, które pozwoli zbudować lokalne łańcuchy logistyczne obejmujące producentów i odbiorców. Celem zarządzania łańcuchem dostaw jest zwiększenie wydajności przy równoczesnej redukcji kosztów magazynowych i operacyjnych oraz dostosowania produkcji energii do potrzeb klientów. Bezpieczne zarządzanie powinno uwzględniać:

- dostawy (zarządzanie dostawami surowców, zapasami, relacje z dostawcami, bazy dostawców),

- sterowanie operacyjne (zarządzanie relacjami z klientami, zarządzanie produkcją, projektowanie sieci dostaw/dystrybucji),

- integrację (zarządzanie strategiczne, infrastrukturą, ryzykiem, pomiarami, wydajnością, ochroną środowiska).

Rozważając zagadnienia dotyczące bezpieczeństwa zarządzania łańcuchem dostaw biomasy z punktu widzenia logistyki, nasuwają się następujące wnioski:

- należy dążyć do stworzenia optymalnych modeli organizacyjnych i logistycznych dla zapewnienia stabilnych dostaw biomasy i zrównoważonego rozwoju obszarów wiejskich;

- w celu uniknięcia przemieszczania dużych mas biomasy na znaczne odległości, zasadne jest tworzenie lokalnych rynków biomasy oraz systemów logistycznych minimalizujących koszty pozyskiwania, transportu i składowania biomasy; 
- wdrażanie i certyfikowanie systemów zapewniania jakości biomasy może wpłynąć w znacznym stopniu na bezpieczeństwo dostaw tak różnorodnego w swoim właściwościach surowca;

- dążenie do zwiększenia udziału biomasyw bilansie produkcji energii elektrycznej w kraju, ze względu na wysokie koszty inwestycji wymaga stosowania odpowiednich systemów wsparcia, będących gwarancją ich systematycznego rozwoju.

\section{Literatura}

Bocian J., 2012: Analiza popytu na biomasę leśną w perspektywie roku 2020, materiały z konferencji „Biomasa leśna”, Łagów.

Dyrektywa Parlamentu Europejskiego i Rady 2009/28/WE z dnia 23 kwietnia 2009 r. w sprawie promowania stosowania energii ze źródeł odnawialnych zmieniająca i w następstwie uchylająca dyrektywy 2001/77/WE oraz 2003/30/WE (Dz. Urz. UE L 140 z 05.06.2009).

Dyrektywa Parlamentu Europejskiego i Rady 2009/72/WE z dnia 13 lipca 2009 r. dotycząca wspólnych zasad rynku wewnętrznego energii elektrycznej i uchylająca dyrektywę 2003/54/WE (Dz.Urz. UE. L. 211 z 14.08.2009).

Energy Law, Acts. U. of 2016. Item. 1165.

Gołębiowska U. (red.), 2013: OZE. Odnawialne źródła energii. Materiał wspierający realizację programu „Odnawialne źródła energii” dla uczniów szkół ponadgimnazjalnych, Koszalin, [źródło elektroniczne] http://www.praktycznyprogram.ekspert sitr.pl/produkty/material_wspomagajacy.pdf [dostęp: 04.05.2019].

GUS, 2015: Energia ze źródeł odnawialnych w 2014 r., Warszawa.

GUS, 2017: Energia ze źródeł odnawialnych w 2017 r., Warszawa.

Grecka K., 2013: Wdrażanie systemu zapewnienia jakości wg normy PN-EN 15234 na przykładzie OPEC-BIO Sp. z o.o., Bałtycka Agencja Poszanowania Energii, [źródło elektroniczne] https://www.slideserve.com/vivian/solidstandards [dostęp: 04.05.2019].

Hryniewicz M., Grzybek A., 2017: Nadwyzka słomy dostępnej do wykorzystania na potrzeby energetyczne w 2016 r. Problemy Inżynierii Rolniczej/Problems of Agricultural Engineering 3(97), 15-31.

Krajowa mapa drogowa odnawialnych źródeł energii, 2010, Polska Izba Gospodarcza Energii Odnawialnej, REPAP 2020, Intelligent Energy Europe 2010.

Krupnik D., 2016: Zarządzanie kompletnym łańcuchem dostaw biomasy do celów energetycznych w aspekcie bezpieczeństwa ekologicznego, [w:] E. Staniewska, Sz. Mitkow (red.), Doskonalenie procesów produkcyjnych i logistycznych w systemie zarządzania organizacją, , Politechnika Częstochowska, Monografia 59, 117-134.

Krupnik D., Mitkow Sz., 2017: Select issues for chain management dekivery biomass, Systemy Logistyczne Wojsk 47, 135-150.

Mirowski T., Mokrzycki E., Uliasz-Bocheńczyk A., 2018: Energetyczne wykorzystanie biomasy, IGSMiE PAN, Kraków.

The National Authentication System Biomass Systems Support Department, Energy Regulatory Office, 2013, 2.

Osiak J., Dwórznik M., System magazynowania, dystrybucji i sprzedaży biomasy. Publikacja współfinansowana ze środków UE w ramach EFS, Towarzystwo Amicus, [źródło elektroniczne] https://www.towarzystwoamicus.pl/images/publikacje/System_magazynowania_dystrybucji_i_sprzedazy_biomasy.pdf [dostęp: 04.05.2019]. 
Polityka energetyczna Polski do 2050 roku, 2015: Ministerstwo Gospodarki. Wersja 05, Ocena realizacji Polityki energetycznej Polski do 2030 roku, Załącznik 1, Warszawa, 1-57.

Polityka energetyczna Polski do 2030 roku, Załącznik do uchwały nr 202/2009 Rady Ministrów z dnia 10 listopada 2009 r., MG, Warszawa 2009.

Postrzednik S., 2014: Wartość opałowa jako parametr przydatności energetycznej biomasy, Energetyka $10,573-578$.

Potencjał i wykorzystanie biomasy w Polsce, energetyka a środowisko, Projekt kół naukowych PW i SGGW, 2011.

Szyszlak-Bargłowicz J., Zając G., Słowik T., 2014: Łańcuch dostaw biomasy na cele energetyczne, Logistyka 6, 354-358 [CD].

Ściążko M., Zuwała J., Pronobis M., 2007: Współspalanie biomasy i paliw alternatywnych w energetyce. Wydawnictwo IChPW i Politechniki Śląskiej, Zabrze - Gliwice.

URE, 2013: Krajowy System Uwierzytelniania Biomasy, Departament Systemów Wsparcia, Warszawa.

Ustawa z dnia 25 sierpnia 2006 r. o biopaliwach i biokomponentach ciekłych (Dz.U. 2016, poz. $266,1165)$.

Ustawa z dnia 20 lutego 2015 r. o odnawialnych źródłach energii (Dz.U. 2019 r. poz. 42, 60, 730).

Węcław-Solny L., 2012: Ograniczenie emisji $\mathrm{CO}_{2}$ w energetyce, Ecomanager 5, 26.

Wnioski z analiz prognostycznych na potrzeby Polityki energetycznej Polski do 2050 roku, załącznik 2 do Polityki energetycznej Polski do 2050 roku, Projekt - wersja 0.2, MG, Warszawa, 1-17.

Zarządzanie logistyczne w sektorze energii odnawialnej, e-Kurs, Elompres LdV Transfer of Innovation, Lifelong Learning, iSpring Suite 8.1, [źródło elektroniczne] bsw.edu.pl [dostęp: 04.05.2019].

Adres do korespondencji:

dr inż. Dorota Krupnik

(https://orcid.org/0000-0002-4735-6245)

Wojskowa Akademia Techniczna

Wydział Logistyki

ul. gen. J. Kaliskiego 2, 00-908 Warszawa

e-mail: dorota.krupnik@wat.edu.pl 



\title{
Ekonomika i Organizacja Logistyki \\ 4 (2), 2019, 55-69
}

DOI: 10.22630/EIOL.2019.4.2.14

\author{
Konrad Michalski ${ }^{1}$, Monika Kowalewska \\ ${ }^{1}$ Szkoła Główna Gospodarstwa Wiejskiego w Warszawie
}

\section{Wladza menedżera logistyki kontraktowej w lańcuchu dostaw}

\section{The authority of the contract logistics manager in supply chain}

Synopsis. Artykuł odnosi się do praktyki działania jednego z liderów rynku TSL (transport, spedycja, logistyka) w Polsce i ma na celu identyfikację kluczowych aspektów władzy menedżera logistyki kontraktowej w łańcuchu dostaw. Przez władzę tę rozumie się możliwości wpływu menedżera na kształt i konfigurację łańcucha oraz przedmioty przepływów i ich cele. Odpowiednie umiejscowienie menedżera logistyki kontraktowej w strukturze organizacyjnej, przypisanie mu właściwych zadań, delegacji do decydowania i zasobów do dyspozycji, to kluczowe atrybuty władzy analizowanego menedżera. Zidentyfikowano typy powiązań, $\mathrm{w}$ jakich uczestniczy badany operator, przedstawiono modelowy proces obsługi klienta z udziałem analizowanego menedżera. Zidentyfikowano pożądany profil kompetencyjny menedżera logistyki kontraktowej i wskazano na kluczowe obszary doskonalenia jego pozycji w łańcuchu dostaw.

Słowa kluczowe: TSL, menedżer logistyki kontraktowej, władza w łańcuchu dostaw

\begin{abstract}
The article refers to the practice of one of the TSL market leaders (transport, forwarding, logistics) in Poland and aims to identify key aspects of the authority (power) of the contract logistics manager in the supply chain. This power is understood as the manager's ability to influence on the shape and configuration of the chain, objects of flows and its goals. The appropriate position of the contract logistics manager in the organizational structure, assigning him the right tasks, delegations to decide and resources at disposal are the key attributes of the authority (power) of the analysed manager. The types of connections in which the analysed operator participates were identified and the model of the customer service process was presented with the participation of the analyzed manager. The profile of desired competence of the contract logistics manager was created and the key areas of improvement of its position in the supply chain were highlighted.
\end{abstract}

Key words: TSL, contract logistics manager, authority on supply chain 


\section{Cele i metody badawcze}

Nadrzędnym celem artykułu jest identyfikacja kluczowych aspektów działań menedżera logistyki kontraktowej w łańcuchu dostaw. Przyjęto, że praktyczne działania każdego menedżera są funkcją m.in. posiadanej przez niego władzy, z której korzysta w środowisku jego pracy, np. w obrębie łańcucha dostaw. Założono również, że sieciowość współczesnych organizacji, wymusza konieczność wchodzenia w bliskie, ale i profesjonalne relacje z innymi uczestnikami łańcucha dostaw. Z kolei wielość i złożony charakter powiązań w praktyce działania łańcuchów dostaw, prowadzić może do problemów związanych z odpowiedzialnością za poszczególne obszary wspólnych działań. W przypadku, gdy brakuje jednoznacznej odpowiedzialności za jakiś proces, zazwyczaj nie jest on doskonalony, a zasadności ciągłego skracania, przyśpieszania, usprawniania itd. (continuous improvement) działań logistycznych w łańcuchu dostaw, nie trzeba dodatkowo uzasadniać.

Chcąc zrealizować cel artykułu, zaprezentowano różne konfiguracje, w jakich uczestniczy badany operator logistyczny i na tej bazie, zidentyfikowano kluczowe elementy działań menedżera nadzorującego proces obsługi klienta kontraktowego. Przedstawiono również $-\mathrm{z}$ wykorzystaniem techniki mapowania - modelowy proces obsługi klienta kontraktowego. Wykorzystano wyniki obserwacji uczestniczących w procesach obsługowych klienta oraz wywiady bezpośrednie z menedżerami badanego operatora.

Pośrednim celem było też określenie pożądanego profilu kompetencyjnego badanego menedżera. Przeprowadzono analizę dokumentacji kadrowej badanego przedsiębiorstwa oraz stworzono zestaw niezbędnych zasobów menedżera logistyki kontraktowej (wiedza, umiejętności, kompetencje społeczne).

\section{Wstęp}

Przykładem stabilnego rynku w Polsce jest TSL (transport, spedycja, logistyka). Na rynku tym ugruntowaną pozycję zajmuje kilku, w większości pochodzących z zagranicy, operatorów logistycznych. Coraz częściej jednak odbiorcy usług na polskim rynku TSL oczekują specjalnego podejścia do realizacji ich potrzeb, co w pewien sposób rekompensuje im ograniczone możliwości zmiany długoletniego partnera (co wynika z długości kontraktu i zazwyczaj obwarowanych różnym i warunkami możliwości jego modyfikacji).

Podejście do klienta na stabilnym rynku TSL powinno umożliwiać mu satysfakcję z bycia obsłużonym w sposób indywidualny, a nie standardowy, poczuciu zaufania do partnera niezawodnego, elastycznego, otwartego na różne opcje współpracy, a w końcu, na gwarancji dostarczenia dokładnie tej jakości, na jaką umówiły się obie strony. W takim rozumieniu produkt (usługa logistyczna) jest emanacją oczekiwań klienta odnoszących się nie tylko do charakterystyk typowo logistycznych, jak koszt, czas, czy jakość (zazwyczaj terminowość).

Wszystkie składowe potrzeby klienta TSL można zamknąć w wartości, dostarczanej mu przez usługę. Naczelną wartością dla klienta kontraktowego (jest to - umownie - w 99\% odbiorca usług TSL) jest poczucie, że operator wspiera - poprzez swoje usługi - jego biznes, że obie strony kontraktu, są de facto częścią jednego systemu, zarządzanego przez menedżera. 
Według Mirońskiego [2000, s. 6], „Zadaniem każdego menedżera jest podejmowanie decyzji i wprowadzanie ich w życie. Aby było to możliwe musi (...) wpływać na innych ludzi i na to co dzieje się w organizacji. Zatem dobry menedżer to menedżer posiadający wpływ. Wpływ natomiast opiera się wyłącznie na posiadanej władzy, zarówno tej formalnej, jak i nieformalnej. Władza jest niczym innym jak potencjalnym wpływem”. Można i należy funkcję pełnioną przez menedżera w łańcuchu dostaw powiązać z wątkiem władzy, zarówno tej danej mu formalnie przez właściciela łańcucha, jak i tej nieformalnej, wypracowanej nierzadko samodzielnie przez menedżera $\mathrm{w}$ toku zarządzania systemem, do którego został delegowany ${ }^{1}$.

Ten system (a właściwie metasystem - gdyż wychodzi on poza system jednej organizacji) to łańcuch dostaw. Władzę menedżera w łańcuchu dostaw należy traktować jako zdolność jego wpływu na podmioty (ogniwa) łańcucha, przedmiot działania (usługi) i konkretne zdarzenia występujące w trakcie jej realizacji. Władza menedżera w łańcuchu dostaw dotyczy też możliwości kształtowania konfiguracji łańcucha i relacji pomiędzy ogniwami. Pełniona funkcja menedżera logistyki kontraktowej będzie zawierała zarówno aspekty władzy gospodarczej, jak i inne, nie mniej ważne wątki, chociażby z obszaru psychologii społecznej, zajmującej się m.in. wywieraniem wpływu, czy dynamiką grup i zespołów pracowniczych. Władza menedżerska jest tym samym narzędziem konkurencyjności operatora logistycznego, jak i całej branży TSL.

\section{Teoretyczne wątki dotyczące władzy menedżera w lańcuchu dostaw}

Teoretycznych podstaw dla artykułu można doszukiwać się w wielu nurtach badawczych. Chcąc w ogóle umiejscowić niniejsze opracowanie w teorii, należałoby wskazać na sieć jako obowiązujący kierunek rozwoju organizacji [Koźmiński i Latusek 2017, s.125], gdzie wysuwają się takie problemy i wyzwania jak komunikacja, współdzielenie, koordynacja w złożonych układach międzyorganizacyjnych o różnym stopniu spójności, elastyczności i zdolności do przekraczania kolejnych barier dla zakresu i skali działań. $\mathrm{W}$ teorii sieci obowiązuje przeświadczenie, że co najmniej na równi z indywidulnymi cechami osobowościowymi menedżera (kierownika) o jego sukcesie decydują kontakty (sieć wpływów), jakimi ten uczestnik ma z innymi członkami sieci [Koźmiński i Latusek 2017, s. 125].

Teoria organizacji branży (industrial organisation, industrial economics) bada dynamiczne aspekty funkcjonowania branży, m.in. strategiczne zachowania organizacji na rynku, władzę i dominację na rynku, inne niż konkurencja, formy koordynacji rynkowych [Jezierski 2015, s. 58-59]. Teoria ekonomii współdzielenia dostarcza inspiracji do poszukiwania możliwości współpracy na wielu płaszczyznach [Poniatowska-Jaksch i Sobiecki 2018], dających możliwości osiągnięcia synergetycznych efektów [Yang i Wu 2008], także w logistyce [Mańkowski 2009].

\footnotetext{
${ }^{1}$ Wątek władzy jest też silnie osadzony na gruncie ekonomii. Zob. m.in: Miroński J., 2007: Problematyka władzy w teorii ekonomii, Gospodarka Narodowa 4, 15-30. W ujęciu ekonomii władzę utożsamia się przede wszystkim z dysponowaniem zasobami, ich lokowaniem i alokacją, dystrybucją i redystrybucją (skala makro) oraz z kierowaniem ludźmi w organizacji w celu realizacji celów, przede wszystkim ekonomicznych (mikro podejście).
} 
Także uważane za alternatywne ujęcia tradycyjnych zagadnień teorii organizacji dostarczają teoretycznych inspiracji dla podjętej problematyki. Przykładem jest podejście do racjonalności, przywództwa, komunikacji, opierające się na społecznej sieci działań i roli aktora [Czarniawska 2010]. Podobnie jak konstrukcja metafor [Morgan 1997], stawiająca do dyspozycji zarządzających wykorzystanie porównań organizacji do ich zrozumienia, diagnozy i doskonalenia. Wśród możliwych do zastosowania obrazów organizacji znajduje się, m.in. porównanie jej do systemu politycznego, gdzie atrybut władzy jest w centrum zainteresowania. Patrząc przedmiotowo na teorię zarządzania, to należy podkreślić, iż zaufanie, wiedza, przywództwo, innowacyjność [Paliszkiewicz 2013, 2019] są czynnikami sukcesu kierujących i zarządzających współczesnymi łańcuchami dostaw.

\section{Definicja lańcucha dostaw i jego klasyfikacja}

Christopher [1992] definiuje łańcuch dostaw, jako sieć organizacji zaangażowanych w przepływy informacji i wspólne procesy rzeczowe (fizyczne). W ten sposób organizacje przyczyniają się do tworzenia wartości dodanej produktom, które jako dobro finalne doręczane są do ich konsumentów. Jest to ujęcie podmiotowe łańcucha, świadczące o tym, że jest on zbiorem samodzielnych organizacji działających wspólnie na rzecz obsługi końcowego klienta. Patrząc na łańcuch dostaw czynnościowo, ma on charakter magazynowo-transportowy, który - przy wsparciu informatycznym - stanowi technologiczne połączenie punktów magazynowych i przeładunkowych na trasach przewozu towarów, a także organizacyjne i finansowe skoordynowanie operacji logistycznych [Gołembska 2009]. Warto zauważyć jeszcze inną definicję łańcucha dostaw, opartą na orientacji przepływowej: to określona sekwencja działań, procesy skupiające się na finalnym odbiorcy, prowadzone zgodnie ze strategią konkurencji, związane z efektywnością i dynamiką zarządzania przepływami fizycznymi, finansowymi, informacyjnymi oraz wiedzą, które towarzyszą ruchowi produktów i realizacji usług w różnych fazach cyklu ich życia [Maternowska 2004].

Pojęcie łańcucha dostaw w każdej z jego interpretacji oparte jest na złożonym zbiorze procesów decyzyjnych dotyczących transformacji przepływów fizycznych, informacyjnych, finansowych i innych, odbywających się w ramach celowo stworzonego układu powiązań biznesowych i logistycznych. Każda definicja łańcucha dostaw ma też wspólne elementy: złożoność, nieprzerywalność, transformację fizycznych obiektów, towarzyszące temu przepływy informacyjne, komunikację, relacje pomiędzy partnerami w łańcuchu.

Podstawowymi ogniwami łańcucha dostaw są dostawca, producent, dystrybutor, hurtownik i odbiorca. Łańcuchy dostaw dzieli się na wewnętrzne i zewnętrzne, krajowe, międzynarodowe i globalne, bezpośrednie, przedłużone i kompleksowe. Najbardziej złożone łańcuchy mają charakter zewnętrzny (składają się z niezależnych ogniw) i globalny. Ten ostatni (globalny) tworzą, w opinii Gołembskiej [2009], przedsiębiorstwa realizujące konfiguracje, która nastawiona jest na budowanie przewagi konkurencyjnej na wielu kontynentach. Przykładem są łańcuchy IT (Apple), motoryzacyjne (Toyota), czy spożywcze (Nestle). 
Kompleksowy łańcuch dostaw stanowi najbardziej rozbudowaną formę, zawierając wszystkie ogniwa zaangażowane w przepływy towarów, modelowo od źródeł wydobycia surowców służących do produkcji dobra, do jego finalnego odbiorcy (konsumenta). Łańcuch taki zakłada uczestnictwo operatora logistycznego, który świadczy usługi, związane z fizycznymi przepływami pomiędzy ogniwami łańcucha. Najszersze łańcuchy obejmują nie tylko fizyczny przepływ materiałów, ale też: dostawców usług IT, finansowych, telekomunikacyjnych [Fechner 2007]. W praktyce gospodarczej współczesne łańcuchy dostaw, wchodzą w skład konkurujących ze sobą globalnych sieci. Niektórzy operatorzy TSL są w stanie zarządzać przepływami fizycznymi nawet w całych sieciach (logistycznych), przejmując w nich także część funkcji zarządczych (operator 4PL - Fourth Party Logistics), także w świecie cyfrowym (operator 5PL - Fifth Party Logistics).

\section{Partnerstwo w lańcuchu dostaw}

W praktyce działania na rynku TSL, można zidentyfikować trzy rodzaje współpracy, opierające się na wymianie informacji i komunikacji pomiędzy ogniwami łańcucha:

- uczestnicy traktują się jak partnerzy, ale ich relacje są zazwyczaj krótkoterminowe i związane jedynie z częścią przedsiębiorstwa, np. działem logistyki; ogniwa wzajemnie się kontrolują i wymieniają jedynie niezbędne do współpracy informacje;

- uczestnicy angażują we współpracę wiele swoich działów i procesów; w takim ujęciu, przykładowym wyrazem takiego partnerstwa jest wspólne projektowaniem procesów, np. zarządzania zapasami, a relacja jest w założeniu długoterminowa;

- partnerstwo strategiczne - w takim modelu ogniwa łańcucha tworzą wspólną politykę i określają sposób zarządzania wszystkimi przepływami; zakłada się równorzędność celów ogniw, tworząc zintegrowany jego zestaw, a do realizacji celów konsumuje się wszystkie możliwości partnerów; w relacji takiej brak współpracy lub jej niska jakość ze strony innego uczestnika powoduje zagrożenie dla realizacji własnych i wspólnych celów.

Na rysunku 1 przedstawiono determinanty partnerskich relacji w łańcuchu dostaw.

Nawet najlepsza technologia i technika, czy najbardziej sprawdzone sposoby działania, nie zastąpią bezpośrednich relacji między partnerami działającymi na rzecz wspólnego celu. Kluczowym elementem łączącym w sposób formalny i nieformalny ogniwa łańcucha są menedżerowie, rozumiani nie jako stanowiska, czy tytuły, ale jako role, podejmujące aktywne działania w złożonym środowisku biznesowym. Potwierdzają to praktycy zarządzania łańcuchami dostaw [Beth i in. 2013]. Spoiwem każdego złożonego systemu, a tym bardziej sieci mogącej się składać z wielu systemów, np. logistycznych, są relacje między uczestnikami, stanowiące pierwszy krok ku partnerstwu. Różnice pomiędzy tradycyjnymi a partnerskimi relacjami w łańcuchu dostaw zaprezentowano w tabeli 1.

Partnerstwo w łańcuchu dostaw stanowi interesujący wątek badawczy związany z rozwijającym się wciąż nurtem współdzielenia w ekonomii (sharing economy). W praktyce logistyki, zwłaszcza w zewnętrznych łańcuchach dostaw, współdzielenie to nie powinno być ograniczane tylko do pracy w ramach wspólnych zasobów, dzieleniu się wiedzą, 


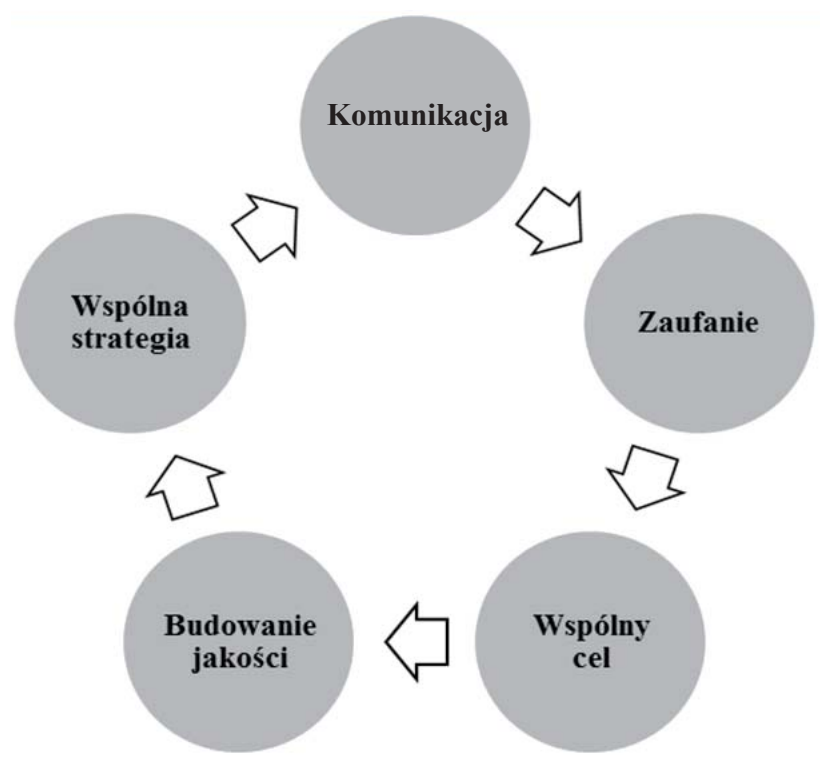

Rysunek 1. Determinanty pozytywnej współpracy w łańcuchu dostaw Figure 1. Determinants of the positive cooperation in supply chain Źródło: opracowanie własne.

Tabela 1. Elementy relacji a myślenie tradycyjne o łańcuchu dostaw

Table 1. Elements of the relationship and traditional thinking on the supply chain

\begin{tabular}{|l|l|}
\hline Tradycyjne relacje dostaw & \multicolumn{1}{|c|}{ Związki podobne do partnerstwa } \\
\hline Podkreślenie istotności ceny przy wyborze dostawcy & Wielorakie kryteria wyboru dostawcy \\
\hline Krótkoterminowe kontrakty dla dostawców & Długoterminowe związki z dostawcami \\
\hline Ocena przetargu z dostawcą & Intensywna ocena wartości dodanej dostawcy \\
\hline Większa baza dostawców & Niewielu, zintegrowanych, zaufanych dostawców \\
\hline Prawnie zastrzeżone informacje & Dzielenie się informacją w poszukiwaniu synergii \\
\hline $\begin{array}{l}\text { Usprawnienie procesu rozwiązywania problemów } \\
\text { determinowane przez ogniwo, które ma władzę } \\
\text { w łańcuchu, następnie dzielenie się sukcesami }\end{array}$ & $\begin{array}{l}\text { Wzajemne rozwiązywanie problemów i dzielenie } \\
\text { się sukcesami (sharing) }\end{array}$ \\
\hline
\end{tabular}

Źródło: opracowanie własne na podstawie [Łupicka 2009, s. 120].

zdolnościami i celami, o czym pisze się już od dawna [Spekman i in., 1998, s. 747-772]. Współdzielenie w nowoczesnych, współczesnych łańcuchach dostaw powinno podążać w kierunku wspólnych idei, wartości, ryzyka, budowania wspólnej przyszłości.

Należy też pamiętać, że władza w każdej organizacji to nie tylko elementy kierowania administracyjnego, gdzie źródłem władzy jest przymus, własność zasobów, pozycja w organizacji i porządek prawny). To coraz częściej przewodzenie, obejmujące pozycję w orga- 
nizacji, porządek prawny, ale też kompetencje, delegowanie uprawnień i autorytet, nadaje ton układom, które osiągają sukces [Łupicka 2009]. Jest to istotne zwłaszcza wtedy, gdy mówi się o strategicznych relacjach, integrowanych także na płaszczyźnie wirtualnej.

\section{Operator logistyki kontraktowej}

W ramach poszukiwania możliwości rozwoju (podejście długookresowe) i/lub obniżki bieżących kosztów (działanie średniookresowe), outsourcing logistyczny jest strategią budowania przewagi konkurencyjnej przedsiębiorstwa. Eksperci logistyczni, tacy jak: DHL, Shenker, Raben, Kuhne+Nagel, czy Rohlig Suus, posiadają umiejętności i zasoby, wystarczające, aby uzyskać akceptację innych ogniw i stać się centrum łańcucha dostaw. Współcześni usługodawcy TSL postrzegani są jako partnerzy strategiczni, a poziom współpracy w łańcuchu dostaw pozwala np. producentowi na osiągnięcie przewagi w branży.

Operatorzy logistyczni odpowiedzialni za organizacje transportu, magazynowania, czy dystrybucji, wychodzą naprzeciw końcowym konsumentom, spełniając ich oczekiwania zgodnie ze znaną zasadą $7 \mathrm{~W}^{2}$. Obowiązki operatora obejmują zapewnienie producenta, że finalny odbiorca będzie usatysfakcjonowany końcowym efektem poprzez np.: terminową, kompleksową i niezawodną dostawę. Operator staje się tym samym podmiotem, który bezpośrednio wpływa na postrzeganie danej marki na rynku.

Usługa logistyki kontraktowej oparta jest na długoterminowej współpracy. W zależności od wymagań klienta outsourcing logistyczny może być zbiorem nawet kilkunastu operacji na rzecz klienta, w tym: dystrybucji towarów, składowania, zarządzania zapasami, co-packingu (przepakowywania) i innych usług o wartości dodanej (VAS).

\section{Opis badanego przedsiębiorstwa $\mathrm{z}$ branży TSL}

Badany operator oferuje:

- outsourcing logistyczny - przykładowo, producent może mieć w strukturach operatora dedykowany magazyn, z którego prowadzona jest dystrybucja towarów; ponadto, operator oferuje usługi VAS, takie jak etykietowanie towarów, tworzenie zestawów promocyjnych, insertowanie (dodawanie materiałów reklamowych do towarów);

- obsługa e-commerce - całościowa obsługa e-sklepów, polegająca na kompleksowym zarządzaniu ich logistyką, w tym na magazynowaniu, np. książek (pakowanie, dostarczanie zamawiającym w sieci, obsługa zwrotów, w tym wymiana itd.);

- usługi transportu drogowego - odbiory i dostawy przesyłek do wielu odbiorców (drobnicowych), przesyłek częściowych (PTL - Part Truck Load), jak i całopojazdowych (FTL - Full Truck Load) do jednego klienta, w trybie obsługi 24/7;

- usługi transportu morskiego i lotniczego - odbiór drogowy towaru z dowolnego miejsca w Polsce lub Europie, a następnie przewóz inną gałęzią transportu;

${ }^{2} 7 \mathrm{~W}-\mathrm{z}$ ang. 7R (rights). W myśl tej zasady dostawca produktu (tutaj operator) jest odpowiedzialny za dostarczenie: właściwego produktu, we właściwej ilości, we właściwym stanie, we właściwe miejsce, o właściwym czasie, właściwemu konsumentowi, po właściwej cenie. 
- logistyka produktów świeżych i szybko psujących - kompleksowa obsługa produktów wymagających temperatury kontrolowanej; klient może korzystać z doświadczenia operatora lub samemu określać wymagania wobec produktów w trakcie np. transportu;

- integracja procesów logistycznych - usługi opierające się na kompleksowych projektach obsługi logistycznej z wykorzystaniem dedykowanej technologii IT, dostępnej także dla klienta (np. WMS - Warehouse Management System - system do zarządzania magazynem, czy TMS - Transport Management System - system do zarządzania transportem); operator oferuje swoje doświadczenie i świadczy usługi doradcze, przejmując kontrolę nad całym łańcuchem klienta, monitorując w jego imieniu przepływ informacji i operacje od transportu surowców do finalnego odbiorcy.

Badany operator stanowi istotne ogniwo w wielu typach łańcuchów dostaw (rys. 2-4).

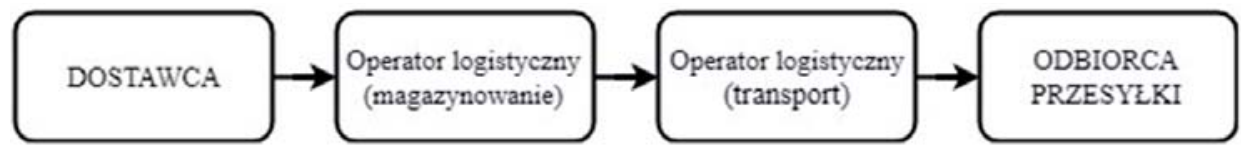

Rysunek 2. Prosty łańcuch kontraktowy z udziałem badanego operatora

Figure 2. A simple contract chain with the participation of the surveyed operator

Źródło: opracowanie własne.

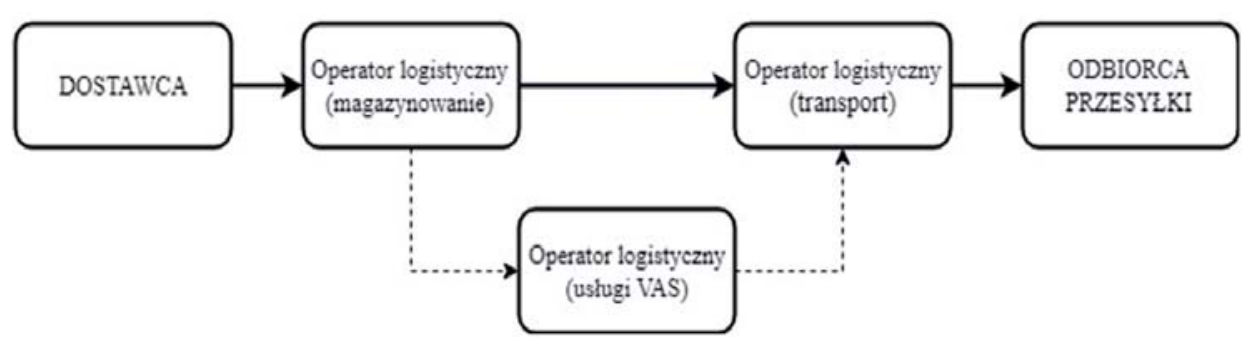

Rysunek 3. Złożony łańcuch kontraktowy z udziałem badanego operatora

Figure 3. A complex contract chain with the participation of the surveyed operator

Źródło: opracowanie własne.

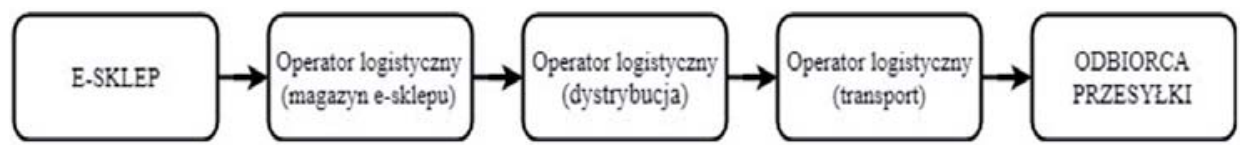

Rysunek 4. Łańcuch e-commerce z udziałem badanego operatora

Figure 4. An e-commerce chain with the participation of the surveyed operator

Źródło: opracowanie własne. 
Począwszy, od łańcucha złożonego (rys. 3), operator świadczy na rzecz klienta wiele usług wartości dodanej. Współpraca dotyczy nie tylko fizycznego procesu obsługi towarów, ale też profesjonalnego doradztwa, np. przy wyborze opakowań zbiorczych dla dostarczanych towarów. Jeszcze większy zakres działania badanego operatora występuje w łańcuchu typu e-commerce (rys. 4), gdzie jest on głównym zarządcą całego układu. Zadaniem e-sklepu jest jedynie złożenie zamówienia i przesłanie go za pomocą formularza EDI do dostarczającego operatora. Pozostałe czynności zarządcze i operacyjne leżą po jego stronie.

\section{Profil kompetencyjny menedżera logistyki kontraktowej badanego przedsiębiorstwa}

Do kluczowych zadań menedżera logistyki kontraktowej w badanej organizacji zalicza się, poza standardowymi oczekiwaniami wobec każdego kierownika, także te specyficzne dla tego stanowiska i środowiska pracy. Ta specyfika bierze się z faktu, że przedmiotowy menedżer to przeważnie samodzielna rola, a osoba ją piastująca nie ma na co dzień podległych pracowników oraz pracuje w strukturze macierzowej, płaskiej i o rozmytych granicach odpowiedzialności. Nie bez znaczenia dla przedmiotowego stanowiska jest to, że każdy, nowy klient wymaga formułowania i planowania innego sposobu jego obsługi, w tym starania się o dedykowane do tego zasoby, w tym bezpośrednich wykonawców.

Menedżer logistyki kontraktowej to przeważnie samodzielny aktor na scenie, gdzie widzem, a zarazem aktywnym uczestnikiem przedstawienia (bieżącej współpracy) jest klient. Dlatego polityka badanej organizacji zakłada, że osoba na przedmiotowym stanowisku musi charakteryzować się nie tylko wieloma twardymi, branżowymi umiejętnościami, ale również tymi, tzw. miękkimi, związanymi z realiami pracy z klientem: świadomym, wymagającym, zmiennym w swoich oczekiwaniach, wywierającym presję, oczekującym maksymalnie indywidualnego podejścia do jego potrzeb i kontaktu w trybie 24/7. Nie należy też zapominać o formułowanych dzisiaj przez operatorów TSL oczekiwaniach wobec wszystkich menedżerów, bez względu na obszar dziedzinowy i poziom działania: ciągła optymalizacja procesów, stałe poszukiwanie synergii w obrębie posiadanych zasobów, rozwój itd. To nie stwarza komfortowych warunków pracy.

Na rysunku 5 przedstawiono standardowy proces obsługi kontraktowej przez badanego operatora.

Analizowany menedżer jest centralną postacią współpracy z klientem i w praktyce ponosi jednoosobową odpowiedzialność (pogrubionym okręgiem zaznaczono czynności, za które osobiście odpowiada) za jej wynik - od pierwszego kontaktu, do przekazania go do realizacji przez komórki operacyjne, a następnie poprzez nadzór nad jego wykonaniem i bieżącą opiekę nad klientem. Zaburzenie któregokolwiek z obowiązków w trakcie procesu może spowodować poważne i wymierne (w formie utraconego zysku) skutki dla przedsiębiorstwa. Dlatego władza, którą przedmiotowa organizacja przekazuje swojemu menedżerowi, wiąże się z dużą odpowiedzialnością. Każdy niezdefiniowany zawczasu błąd, może doprowadzić do utraty ciągłości pracy, np. w magazynie centralnym klienta lub do innych opóźnień w realizacji.

Przedmiotowe stanowisko poddane zostało analizie, która pozwoliła określić obowiązki, zadania oraz sposoby mierzenia wyników pracy analizowanego menedżera (tab. 2). 


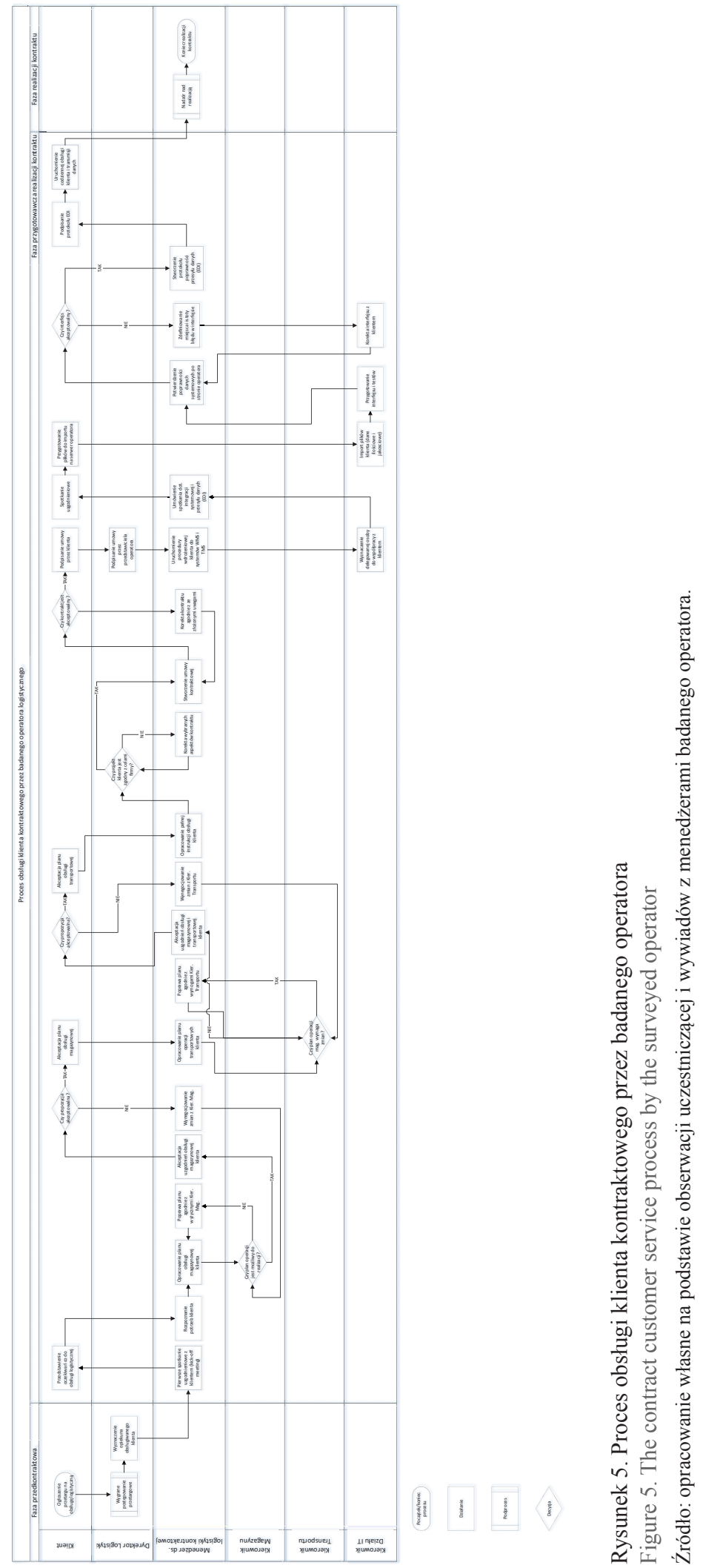


Tabela 2. Profil stanowiska menedżera logistyki kontraktowej badanego operatora Table 2. Profile of the position of contract logistics manager of the surveyed operator

\begin{tabular}{|c|c|}
\hline $\begin{array}{l}\text { Miejsce } \\
\text { w przedsiębiorstwie }\end{array}$ & Dział logistyki kontraktowej \\
\hline Cele & $\begin{array}{l}\text { - projektowanie i zarządzanie operacjami w zakresie łańcucha dostaw, } \\
\text { - } \text { zarządzanie portfelem klientów prowadzące do zwiększenia satysfakcji klientów } \\
\text { oraz rozwoju przedsiębiorstwa, } \\
\text { - } \text { realizowanie zaplanowanego budżetu, } \\
\text { - } \text { koordynowanie i nadzór nad kontraktem, } \\
\text { - dążenie do optymalizacji procesów. }\end{array}$ \\
\hline Zakres działania & - liczba klientów: 2-5; przychód portfela klientów: zgodnie z budżetem. \\
\hline Kluczowe działania & $\begin{array}{l}\text { - wdrożenie klienta do struktur operatora } \\
\text { - stworzenie planu sprzedaży - cele: przychód, zysk i satysfakcja klienta, } \\
\text { - zarządzanie kanałami dystrybucji, } \\
\text { - utrzymanie dobrych relacji z klientem, } \\
\text { - negocjowanie i aktualizowanie warunków umowy, } \\
\text { - analizowanie zmian i trendów rynku logistycznym. }\end{array}$ \\
\hline Wskaźniki & $\begin{array}{l}\text { - terminowość dostaw klientów (\%) } \\
\text { - plan budżetowy posiadanego portfela klientów (PLN) } \\
\text { - bilans przepływów ładunków (w jednostkach ładunku) } \\
\text { - KPI’s (Key Performance Indicators) }\end{array}$ \\
\hline Współpraca & $\begin{array}{l}\text { Działy: Transportu, Księgowy, Magazynowy, Handlowy. } \\
\text { Klienci - codzienne rozwiązania, polityka cenowa, szczegóły kontraktu itd. }\end{array}$ \\
\hline Kwalifikacje & Wykształcenie wyższe, preferowane: transport, logistyka, zarządzanie projektami. \\
\hline Doświadczenie & Min. 4-letnie doświadczenie w firmie zajmującej się logistyką. \\
\hline Umiejętności & Programy WMS i TMS; narzędzia mobilne dla logistyki; prawo jazdy kat. B \\
\hline Języki obce & Angielski na poziomie minimum B2/C1. \\
\hline Profil osobowy & $\begin{array}{l}\text { szeroka wiedza z zakresu logistyki kontraktowej, umiejętności organizacyjne, kiero- } \\
\text { wania zespołem, umiejętności zarządzania budżetem i świadomość kosztowa, strate- } \\
\text { giczne, kreatywne myślenie, umiejętności dyplomatyczne. }\end{array}$ \\
\hline
\end{tabular}

Źródło: opracowanie własne na podstawie analizy dokumentacji i wywiadów w badanym przedsiębiorstwie.

\section{Kierunki zmian w zakresie funkcjonowania menedżera logistyki kontraktowej w lańcuchu dostaw}

Praktyka działania liderów logistycznych wskazuje, że sukces w biznesie uzależniony jest często od niedostrzegalnych na co dzień czynników, jak np. dyscypliny w wykonywaniu procedur, niebagatelizowania pozornie nieistotnych spraw, zrozumienia filozofii „niechodzenia na skróty”, czy też praktykowania kreatywności w codziennym działaniu, także menedżera. Do tego dochodzi dążenie kierownictwa w poszczególnych częściach rozproszonej struktury do wyznaczania priorytetów, z uwzględnieniem lokalnej specyfiki rynku czy oddziału firmy, ale działających na rzecz całej organizacji [Bielicki 2016].

Na podstawie badanego operatora TSL można skonstruować wnioski dotyczące ważnych zmian w zakresie miejsca i roli menedżera logistyki kontraktowej w łańcuchu do- 
staw, będących podstawowym źródłem jego władzy (gospodarczej). Postulaty zwiększają w założeniu możliwości menedżera co do skutecznego wpływy na relacje z klientem, jak i całą organizację:

- rzeczywista, a nie deklarowana elastyczność współpracy - w praktyce istnieją niedociągnięcia $\mathrm{w}$ podejściu badanego operatora do potrzeb klienta; menedżer, mimo zaangażowania i chęci budowania dedykowanych rozwiązań jest poważnie ograniczony kontraktem, a zgodnie z polityką korporacyjną przedsiębiorstwa, nie ma możliwości wdrożenia nowego rozwiązania bez akceptacji przełożonego; takie podejście wiąże się z długim okresem wdrażania koncepcji i metod działania, a konieczność wykonania dodatkowych czynności prowadzi do wydłużenia czasu reakcji na zgłaszany problem i mija się z deklarowaną polityką otwartości operatora - wymagana byłaby elastyczność obu stron w postrzeganiu ram umowy, a nie jej zapisów explicite;

- kompleksowe przygotowanie do nowych rodzajów obsługi - nadążając za trendami, operator umieszcza w swojej ofercie propozycje nowych usług, np. dla obszaru e-commerce, będącego motorem napędowym dostaw [Kawa 2018]; menedżerowie operatora nie są przygotowani w pełni do obsługi tego segmentu usług i często we własnym zakresie dowiadują się o nowych, dostępnych kanałach świadczenia usług, a tymczasem sami klienci (np. wydawcy multimediów) są zainteresowani poszerzeniem swoich sieci sprzedaży o e-sklep; taka sytuacja buduje negatywny wizerunek menedżera w oczach klienta, jako osoby niekompetentnej; potrzebne jest podjęcie kroków, chociażby w zakresie cyklicznych szkoleń o nowościach usługowych na rynku;

- wdrażanie rozwiązań akceptowalnych przez klienta - przykładowo, w związku z rozwojem nowych technologii kompletacji zleceń, firma wdraża systemy ułatwiające prace, np. w magazynie, co teoretycznie powinno satysfakcjonować klienta; tymczasem, menedżer spotyka się z negatywnymi opiniami na temat proponowanych rozwiązań: odbiorcy obsługiwanych klientów kontraktowych wymagają bowiem wykonywania czynności dodatkowych, które w praktyce uniemożliwiają zastosowanie przez operatora innowacji; menedżer musi podejmować wyzwanie i przekonywać partnerów do zmiany stanowiska, a nie wdrażać kontrakty, które później są „,robione po staremu, bo klient tak chce"; dodatkowo potrzebna jest szersza i bardziej skuteczna polityka informacyjna, w tym edukacyjna, pokazująca klientów korzyści ze zmian o charakterze innowacyjnym,

- uprawnienia w zakresie rozwiązań IT - menedżer tworzący wiele zestawień, raportów, analiz itd., nie jest w stanie zgromadzić całości informacji w wersji papierowej, a zarejestrowanie ich w mobilnej bazie danych jest też sporym wyzwaniem; dodatkowo praca w łańcuchu dostaw wymaga udostępniania lub poszerzania klientom dostępu do dedykowanych logistyce rozwiązań IT: menedżer musi być na bieżąco z możliwościami tych modyfikacji, a takie, wprowadzane na bieżąco zmiany w zakresie dostępu klienta do systemów, mogłyby istotnie ograniczyć ilość przesyłanych na bieżąco informacji, w tym pomiędzy menedżerem a klientem; nie bez znaczenia jest też ograniczenie manualnych czynności operacyjnych wykonywanych przez menedżera - potrzebna jest zmiana w zakresie scedowania przez dział IT niektórych uprawnień na poziom menedżera, np. w zakresie modyfikacji interfejsu klienta. 


\section{Podsumowanie i wnioski}

Menedżer logistyki kontraktowej pełni strategiczną funkcję w logistycznej obsłudze klienta w łańcuchu dostaw, co powinno się przekładać na właściwy (optymalny) zakres jego władzy w układzie biznesowo-logistycznym, w którym funkcjonuje. Mimo iż menedżer logistyki kontraktowej nie bierze czynnego udziału w codziennych operacjach na rzecz klienta, jest on de facto odpowiedzialny za utrzymanie ich wysokiego standardu realizacji. Jego zadaniem jest budowanie „wspólnego systemu” z klientem, w którym wszelkie informacje zwrotne są zgodne z kontraktem oraz zapewniają maksymalną satysfakcję obu stron. W zależności od oczekiwań usługobiorcy, menedżer staje przed wyzwaniem projektowania łańcucha odpowiadającego dystrybucji danego rodzaju towaru. W praktyce niemożliwe jest wypracowanie jednego modelu łańcucha dostaw i wykorzystanie go przy obsłudze całego portfela klientów, z różnych branż. Mimo tego, że stopień zindywidualizowania realizowanych łańcuchów dostaw jest duży, to możliwe jest jednak wypracowywanie pewnych wzorców działania, dobrych praktyk, powielanych w mniejszym lub w większym zakresie do obsługi kolejnych klientów.

$\mathrm{W}$ badanym przedsiębiorstwie menedżer logistyki kontraktowej to osoba-aktor, mający za zadanie rozpoznać potrzeby klienta i aktywnie uczestniczyć w procesie rozwijania wspólnych działań. Reprezentując stanowisko o strategicznym znaczeniu, menedżer tworzy politykę zarządzania łańcuchem oraz buduje wizerunek operatora. Źródłem praktycznej przewagi menedżera jest jego doświadczenie w branży logistycznej - im większe, tym możliwości efektywnego działania w łańcuchu mogą być skuteczniejsze i bardziej efektywne. Wyrazem realnej i zaawansowanej władzy analizowanego menedżera jest przekazanie mu przez klienta komórki logistycznej, nad którą ma sprawować nadzór w trakcie obsługi kontraktu, ma sprawować przedmiotowy menedżer. Jednocześnie, taki krok ze strony klienta, to najlepsza nagroda, uznanie i akceptacja dla realizowanych wspólnie działań, w jednym systemie, jakim jest łańcuch dostaw.

Patrząc na zestaw kompetencji, jakimi powinien charakteryzować się analizowany menedżer widać specyficzną cechę: to jednoosobowy reprezentant interesów pracodawcy i klienta, którego praktyka działania obejmuje zarządzanie wieloma projektami obsługowymi, rzadko jednym kontraktem. Wymaga to od niego zdolności nie tylko ustalania priorytetów, ale także zarządzania nimi, w tym dokonywania wyborów o delegowaniu zadań. Poza tym koordynacja bieżących, taktycznych i dalekosiężnych działań w czasie - timing, którego istota bazuje na wykonywaniu właściwych zadań we właściwym czasie - staje się kluczową umiejętnością menedżera. Nie wszystkie wyżej wymienione, wciąż ewoluujące kompetencje menedżerskie, wynikać powinny z zapisów takiego, a nie innego profilu kompetencyjnego. Kompetencje te powinny być pokłosiem analizy mega zmian, determinujących rozwój wielu branż oferujących szeroko rozumiane usługi oparte na przepływach strumieni logistycznych. A zmiany te są epokowe. Coraz mniej fizyczności, a więcej cyfrowej postaci przepływów, będzie powodowało nie tylko zmiany w sposobach działania (technologiach) operatorów logistycznych, ale i wymagało od nich budowania nowych relacji w łańcuchach dostaw, prawdopodobnie też z udziałem sztucznej inteligencji [Michalski 2019]. To będzie $\mathrm{z}$ kolei rodziło kolejne wyzwania w aspekcie władzy gospodarczej w budowanych układach logistycznych. 


\section{Literatura}

Beth S., Burt D.N., Capacino W., Gopal Ch., Hau Lee L., Lynch Porter R., Morris S., 2013: Wyzwania w łańcuchu dostaw: budowanie relacji, [w:] Sztuka zarządzania łańcuchami dostaw, ICAN Institute, Warszawa, 147-165.

Bielicki M., 2016: Wybrane aspekty wchodzenia zachodnich operatorów na polski rynek logistyczny, [w:] Zeszyty Naukowe SGGW w Warszawie. Ekonomika i Organizacja Logistyki $4,17-21$.

Czarniawska B., 2010: Trochę inna teoria organizacji. Organizacja jako konstrukcja sieci działań, Wydawnictwo Poltext, Warszawa.

Christopher M., 1992: Logistics and Supply Chain Management, Pitman Publishing, Londyn.

Fechner I., 2007, Zarządzanie łańcuchem dostaw, WSL, Poznań.

Gołembska E., 2009: Logistyka w gospodarce światowej, C.H. Beck, Warszawa.

Jezierski A., 2015: Konkurowanie logistyką w warunkach kryzysu w świetle teorii organizacji branży, [w:] J. Witkowski, A. Skowrońska (red.), Strategie i logistyka w warunkach kryzysu, Prace Naukowe Uniwersytetu Ekonomicznego we Wrocławiu 382, 53-65.

Kawa A., 2018: Branża KEP na fali wzrostu, Logistyka 1, 17-22.

Koźmiński A.K., Latusek-Jurczak D.: 2017, Rozwój teorii organizacji. Od systemu do sieci, Wydawnictwo Poltext, Warszawa.

Łupicka A., 2009: Formy koordynacji rynkowej w łańcuchach dostaw, Wydawnictwo Naukowe Uniwersytetu Ekonomicznego w Poznaniu, Poznań.

Mańkowski C., 2009: Synergia w logistyce, Wydawnictwo Uniwersytetu Gdańskiego, Gdańsk.

Maternowska M.:, 2004: Łańcuch dostaw - zagadnienia wybrane, Logistyka 3, 21-24.

Michalski K., 2019: Megatrendy rozwojowe współczesnej branży pocztowej, Zeszyty Naukowe SGGW w Warszawie. Polityki Europejskie, Finanse i Marketing, 21, 172-185.

Miroński J., 2000: Władza i polityka w przedsiębiorstwie. Zarządzanie przez wpływ, Difin, Warszawa, [źródło elektroniczne]: https://www.researchgate.net/publication/313116620_ Wladza_i_polityka_w_przedsiebiorstwie [dostęp: 18.06.2019].

Miroński J., 2007: Problematyka władzy w teorii ekonomii, Gospodarka Narodowa 4, 15-32.

Morgan G., 1997: Obrazy organizacji, Wydawnictwo Naukowe PWN, Warszawa.

Paliszkiewicz J., 2019: Przywództwo, zaufanie i zarządzanie wiedzą w innowacyjnych przedsiębiorstwach, CeDeWu, Warszawa.

Paliszkiewicz J., 2013: Zaufanie w zarządzaniu, Wydawnictwo Naukowe PWN, Warszawa.

Poniatowska-Jaksh M., Sobiecki R. (red.), 2018: Sharing economy, Oficyna Wydawnicza SGH, Warszawa.

Spekman R.E., Forbes T.M., Isabella L.A., MacAvoy T.C., 1998: Alliance management: a view from the past and a look to the future, Journal of Management Studies 35, 747-772.

Yang H.L., Wu T.C.T., 2008: Knowledge sharing in an organization, Technological Forecasting and Social Change 75, 1128-1156. 
Władza menedżera logistyki kontraktowej...

Adresy do korespondencji:

dr Konrad Michalski

(https://ordid.org/0000-0001-6997-352X)

Szkoła Główna Gospodarstwa Wiejskiego w Warszawie

Katedra Logistyki

ul. Nowoursynowska 166, 02-787 Warszawa tel.: (+48) 225935603

e-mail: konrad_michalski@sggw.pl

mgr Monika Kowalewska

Danfoss Poland sp. z o.o.

ul. Chrzanowska 5, 05-825 Grodzisk Mazowiecki

e-mail:monikalach00@gmail.com 



\title{
Ekonomika i Organizacja Logistyki \\ 4 (2), 2019, 71-80
}

DOI: 10.22630/EIOL.2019.4.2.15

\author{
Maria Michalowska ${ }^{1}$, Nina Wielgórska ${ }^{2}$ \\ ${ }^{1}$ Górnośląska Wyższa Szkoła Handlowa w Katowicach \\ ${ }^{2}$ Uniwersytet Ekonomiczny w Katowicach
}

\section{Możliwości usprawnienia procesu dystrybucji produktów tłuszczowych na przykładzie firmy branży FMCG}

\author{
Improvement possibilities of the distribution process \\ of oils and fats on the example of a FMCG company
}

\begin{abstract}
Synopsis. W artykule podjęto problem wybranych aspektów dystrybucji produktów tłuszczowych w działalności przedsiębiorstwa branży FMCG (ang. Fast Moving Consumer Goods). Wskazano istotną rolę zarządzania łańcuchem dostaw w realizacji misji firmy, której specyfika powoduje stałe poszerzanie portfolio produktów z wykorzystaniem przyjaznych ekologicznie technologii. Zaprezentowano przydatność instrumentów zarządzania łańcuchem dostaw takich jak: mapowanie procesów, diagram Ishikawy oraz analizę TUL dla usprawnienia funkcjonowania badanego podmiotu w zakresie przemieszczania wyrobów gotowych od miejsc ich wytworzenia do konsumenta.
\end{abstract}

Słowa kluczowe: dystrybucja, zarządzanie łańcuchem dostaw, mapowanie procesów, diagram Ishikawy, analiza TUL

\begin{abstract}
The article discusses selected aspects of fat distribution in the activity of FMCG (Fast Moving Consumer Goods) company. An important role of supply chain management in the implementation of the company's mission has been indicated, the specificity of which results in the constant expansion of the product portfolio using eco-friendly technologies. The usefulness of supply chain management instruments such as: process mapping, Ishikawa diagram and TUL analysis for improving the functioning of the examined entity in the scope of moving finished products from the places of their production to the consumer was presented. Key words: distribution, supply chain management, process mapping, Ishikawa diagram, TUL analysis
\end{abstract}

\section{Wstęp}

Dystrybucja to istotne ogniwo logistyczne w każdym przedsiębiorstwie, które łączy producenta z konsumentem. Jest częścią łańcucha dostaw zdefiniowanego przez Witkowskiego [2010] jako zbiór współdziałających ze sobą firm wydobywczych i przetwórczych, handlowych, usługowych oraz ich klientów, pomiędzy którymi przepływają stru- 
mienie dóbr rzeczowych, środków finansowych oraz informacji. Dla przedsiębiorstwa produkcyjnego dystrybucja to wszelkie działania związane z dostarczeniem właściwego produktu do ostatecznego odbiorcy w zamówionej ilości i o właściwej jakości, w odpowiednie miejsce, w odpowiednim czasie, po optymalnych kosztach i przy zachowaniu właściwego poziomu obsługi [Rutkowski 2005]. W przypadku dystrybucji produktów szybko rotujących zakłada się pokonywanie odległości przestrzennej w jak najkrótszym czasie, w celu zapewnienia klientowi produktu o jak najdłuższym okresie przydatności. Dla zminimalizowania ryzyka zniszczenia produktu na skutek przeterminowania przedsiębiorstwa dążą do realizacji strategii typu pull poprzez zbudowanie bliskich relacji z nabywcą, tak, aby konsument inicjował proces wytwarzania [Encyklopedia Zarządzania].

Realizacja celów przedsiębiorstwa w zakresie dystrybucji wymaga podejmowania wielu kluczowych decyzji oraz wykonywania licznych czynności o charakterze koordynacyjno-organizacyjnym. W podejściu logistycznym decyzje i działania dotyczące dystrybucji mają związek z optymalnymi metodami transportowania i magazynowania, pakowaniem, zarządzaniem zamówieniami, zapasami i gospodarką magazynową, obsługą klienta, zaopatrzeniem i zakupami, lokalizacją obiektów, logistyką zwrotną lub międzynarodową. Wymienione czynności mogą być realizowane przy zastosowaniu różnorodnych instrumentów zarządzania łańcuchem dostaw [Murphy i Wood 2010].

\section{Cel i metodyka badań}

Celem artykułu jest rozpoznanie możliwości usprawnienia procesów dystrybucji w przedsiębiorstwie branży spożywczej, zajmującym się wytwarzaniem oraz sprzedażą wyrobów tłuszczowych jadalnych pochodzenia roślinnego na rynek europejski. Ze względu na rozbudowane portfolio produktów istotne znaczenie w realizacji misji badanego podmiotu odgrywa zarządzanie łańcuchem dostaw. Łańcuch dostaw odgrywa ważną rolę $\mathrm{w}$ dostarczaniu produktu gotowego do klienta końcowego, poczynając od pozyskania surowców i komponentów oraz dostarczenia ich do fabryki, aż do dotarcia wyrobu finalnego do konsumenta. Podstawowe elementy w łańcuchu dostaw badanego podmiotu to: dostawcy, zakład produkcyjny (miejsce wytwarzania produktu gotowego), centra dystrybucyjne, magazyny oraz sklepy i inne obiekty umożliwiające zakup produktu gotowego przez klienta końcowego. Elementy te są powiązane przez sieć transportową, w której wyróżnia się trzy rodzaje transportu:

- transport przychodzący, czyli transport surowców i opakowań pomiędzy dostawcami a fabryką;

- transport pierwszorzędny, polegający na przemieszczaniu produktu gotowego, po zakończeniu wytwarzania, z fabryki do wybranego centrum dystrybucyjnego;

- transport drugorzędny, to jest transport pomiędzy centrum dystrybucyjnym a klientem (np. sklepem detalicznym, supermarketem).

Przeprowadzone badania empiryczne, związane z tytułowym problemem artykułu, dotyczyły transportu pierwszorzędnego, tzn. transportu produktów gotowych do jednego $\mathrm{z}$ centrów dystrybucyjnych. Zgodnie $\mathrm{z}$ wewnętrzną terminologią badanego przedsiębiorstwa, centrum dystrybucyjne stanowi obiekt, którego zadaniem jest przyjmowanie dostaw produktów gotowych z fabryki, ich podział, a następnie łączenie z zaplanowanymi wysyłkami do klientów. 
Realizując cel opracowania, przyjęto hipotetyczne założenie, że zastosowanie narzędzi zarządzania łańcuchem dostaw w przedsiębiorstwie, takich jak mapowanie procesów, diagram Ishikawy, czy metoda TUL, przyczynia się do usprawnienia jego funkcjonowania.

Bazę źródłową badań stanowiły wyniki studiów literatury z zakresu logistyki dystrybucji oraz materiałów wtórnych udostępnionych w badanym przedsiębiorstwie. Wykorzystano także obserwacje oraz własne doświadczenia zdobyte podczas wykonywania obowiązków zawodowych w analizowanym podmiocie.

\section{Wyniki badań}

\section{Mapowanie procesu dystrybucji produktów tluszczowych z zakładu produkcyjnego do centrów dystrybucyjnych}

Mapowanie procesów jest techniką umożliwiającą przedstawienie ich przebiegu za pomocą map, które stanowią graficzne odwzorowanie procesów w taki sposób, który pozwala prześledzić i zrozumieć ich przebieg [Peppard i Rowland 1997]. Głównym celem mapowania procesu jest analiza działania pojedynczych procesów lub zespołów operacji wraz z ich wzajemnymi zależnościami. Mapę procesu transportu pierwszorzędnego polegającego na przemieszczeniu produktów tłuszczowych z zakładu produkcyjnego do centrum dystrybucyjnego przedstawiono na rysunku 1.

Jak wynika z treści mapy, proces produkcyjny w przedsiębiorstwie rozpoczyna się od zgłoszenia zapotrzebowania przez klienta (strategia ssąca). Klient ma możliwość wysłania zamówienia przy użyciu dwóch kanałów informacyjnych: poprzez pocztę elektroniczną i aplikację internetową. Po sprawdzeniu kompletności danych zamówienia przez centralny zespół sprzedaży zostaje ono zasygnalizowane w całym łańcuchu dostaw poprzez wprowadzenie informacji do systemu SAP ERP. Zakład produkcyjny po otrzymaniu zamówienia planuje produkcję wyrobu w długoterminowym oraz krótkoterminowym harmonogramie produkcji. Następnym krokiem jest sprawdzenie, czy niezbędne surowce oraz materiały opakowaniowe zostaną dostarczone na czas. Ze względu na małą powierzchnię magazynową dostarcza się tylko niezbędne materiały do produkcji, dlatego niezwykle ważna jest relacja klient-producent.

Po wytworzeniu produktu fabryka wysyła do centralnego zespołu logistycznego informację o konieczności zorganizowania transportu pomiędzy przedsiębiorstwem a centrum dystrybucyjnym. Koordynatorzy zgłaszają do zakontraktowanych operatorów potrzebę wykonania usługi transportowej i ustalają termin realizacji, zgodny z planem produkcji. Oferta przewozowa zawiera niezbędne dane o ładunku takie jak: ilość, waga, data załadunku oraz rozładunku, miejsce rozładunku, wymogi transportowe. Po zatwierdzeniu wykonania usługi zostają przygotowane dokumenty przewozowe w systemie SAP ERP.

Kierowca po otrzymaniu zlecenia od spedytora przystępuje do jego zrealizowania. Na miejscu załadunku zostają sprawdzone numery rejestracyjne pojazdu w bazie danych awizacji, a następnie samochód ciężarowy oczekujący na parkingu zakładu produkcyjnego zostaje podstawiony do doku załadowczego dziesięć minut przed rozpoczęciem produkcji asortymentu. Przewoźnik jest zobowiązany do:

- prawidłowego podstawienia samochodu pod dok załadowczy, 


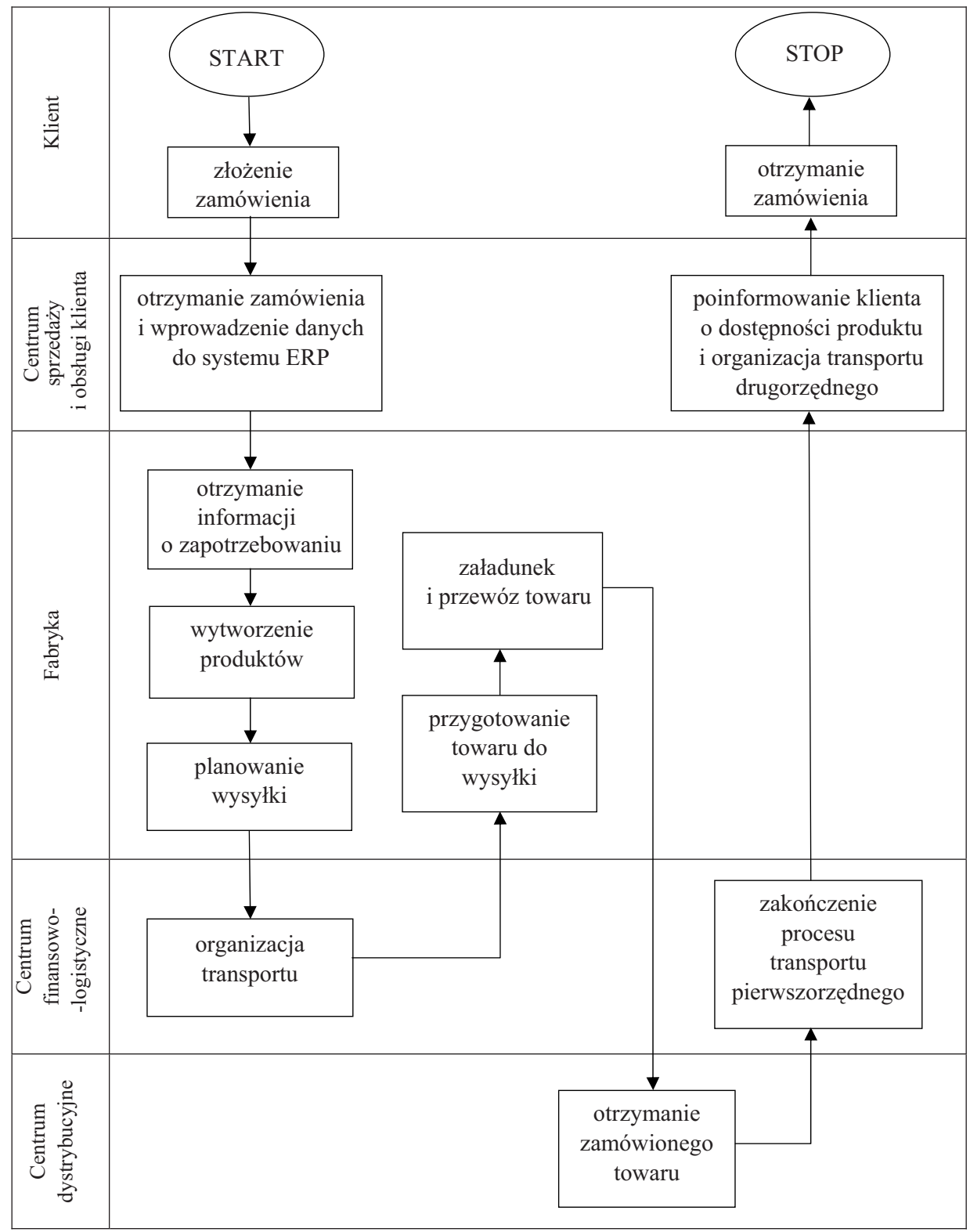

Rysunek 1. Mapa procesu transportu pierwszorzędnego w badanym przedsiębiorstwie Figure 1. Map of the primary transport process in the surveyed enterprise

Źródło: opracowanie własne. 
- prawidłowego zabezpieczenia drzwi naczepy,

- zabezpieczenie kół klinami,

- zabezpieczenie towaru tyczkami,

- utrzymania odpowiedniej temperatury w naczepie,

- zapewnienia czystości środka transportu,

- sprawdzenia zgodności ilości ładowanych palet z dokumentami przewozowymi,

- sprawdzenia rozmieszczenia palet na naczepie.

Załadunek palet z wyrobem gotowym na samochód ciężarowy odbywa się bezpośrednio z linii produkcyjnej po pomiarze temperatury naczepy. Palety są formowane, owijane folią oraz etykietowane przez urządzenia pakujące. Następnie, magazynier pobiera palety wózkiem widłowym z obszaru odkładczego znajdującego się za paletyzatorem na końcu linii produkcyjnej i przemieszcza je na ciągnik siodłowy samochodu. Stanowisko załadunku składa się z pięciu doków załadowczych, które wyposażone są w automatyczne bramy skanujące kod etykiety. Dane są aktualizowane na bieżąco w systemie SAP ERP. Po wykonaniu wszystkich czynności magazynowych operator nadzoruje zabezpieczenie załadowanego towaru przez kierowcę i wydaje mu niezbędne dokumenty przewozowe.

W trakcie realizacji usługi transportowej kierowca dokonuje przewozu wyrobu gotowego z zakładu produkcyjnego do centrum dystrybucyjnego. W miejscu docelowym następuje sprawdzenie zgodności transportu $\mathrm{z}$ awizacją oraz dokumentami przewozowymi i po uzyskaniu akceptacji, pojazd zostaje skierowany do właściwej rampy rozładunkowej. Pracownik centrum dystrybucyjnego, który odbiera wyrób gotowy, dokonuje ponownej kontroli zgodności zamówienia oraz ocenia stan jakościowy przesyłki (sprawdza, czy produkt jest zgodny z dokumentem wydania, czy ilość produktu jest zgodna $z$ dokumentem wydania, czy folia ochronna na palecie jest nienaruszona, czy wyrób na palecie nie jest przechylony, czy wyrób na palecie nie jest zmiażdżony, czy produkt ma odpowiednią temperaturę). W razie wystąpienia niezgodności sporządzany jest protokół reklamacyjny potwierdzony przez kierowcę oraz pracownika magazynu.

Po wykonaniu usługi przewozu następuje rozliczenie kosztów. Przedsiębiorstwo transportowe przesyła notę rozliczeniową do centralnej jednostki finansowej firmy. Dane zostają wprowadzone do systemu i są wysyłane do akceptacji do spedytora, który analizuje efekt usługi. W przypadku wystąpienia niezgodności nota zostaje odrzucona i przedsiębiorstwo transportowe dokonuje korekty faktury. Termin płatności i sposób zapłaty jest określony w kontrakcie. Zakończenie usługi następuje w momencie otrzymania zapłaty przez przewoźnika. Informacja o dostępności produktu w centrum dystrybucyjnym jest przekazywana klientowi przez centralne biuro obsługi klienta.

Przedstawiona analiza studium przypadku w wyniku zastosowania techniki mapowania wybranego aspektu dystrybucji w analizowanym podmiocie potwierdza przydatność tej techniki dla zrozumienia elementów procesu, zdefiniowania jego zakresu oraz wskazania punktu odniesienia, względem którego można wskazywać udoskonalenia. 


\section{Analiza przyczynowo-skutkowa wybranego problemu z wykorzystaniem diagramu Ishikawy}

W trakcie próby oceny aspektów procesu dystrybucji badanego przedsiębiorstwa zwraca uwagę problem nieterminowych dostaw. Aby zdefiniować potencjalne przyczyny opóźnienia w dostawach, opracowano diagram przyczynowo-skutkowy, zwany diagramem szkieletowym, albo diagramem Ishikawy [Bozarth i Handfield 2007]. Zastosowano pięć kategorii przyczyn: materiały, ludzie, maszyny, zarządzanie i środowisko (rys. 2).

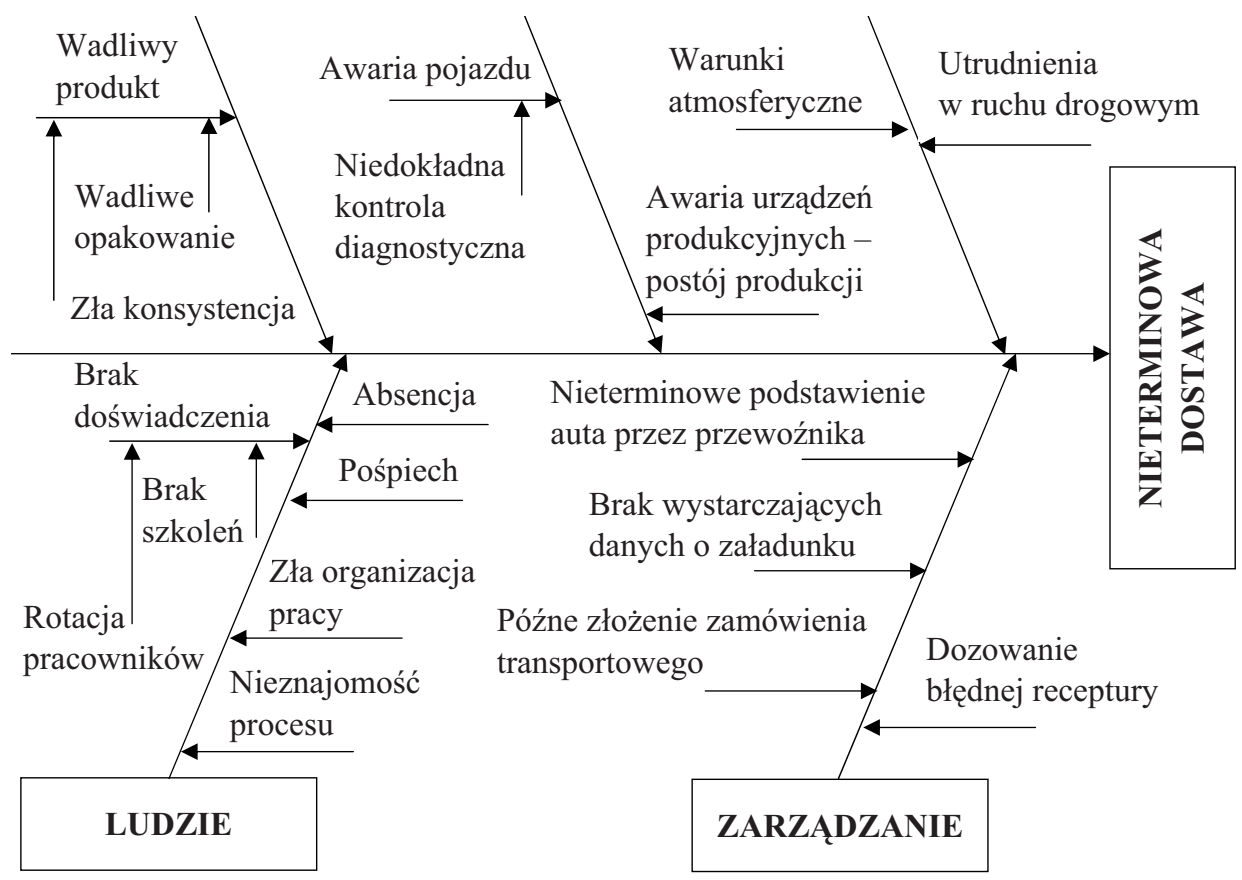

Rysunek 2. Diagram przyczynowo-skutkowy dla nieterminowej dostawy

Figure 2. Cause and effect diagram for untimely delivery

Źródło: opracowanie własne.

Analiza diagramu pozwala zauważyć, że największy wpływ na nieterminową dostawę ma opóźnienie związane z niepunktualnym przybyciem pojazdu do punktu załadunku. Brak samochodu ciężarowego oddziałuje bezpośrednio na postój linii produkcyjnej - produkcja wyrobu gotowego nie może zostać rozpoczęta przed podstawieniem pojazdu pod rampę załadunkową ze względu na bardzo małą przestrzeń magazynową. Tym samym następuje opóźnienie załadunków kolejnych pojazdów, a niepunktualny kierowca ma wydłużony czas oczekiwania na rozładunek w centrum dystrybucyjnym, jeżeli nie zdąży dostarczyć produktu w wyznaczonym dla niego przedziale czasowym. Inną ważną przyczyną jest brak wystarczających danych o załadunku. Na przykład, przewoźnik zostaje poinformowany mylnie o godzinie załadunku i/lub otrzymuje niepoprawny adres 
dostawy od spedytora. Częstym powodem tych błędów jest zmiana sekwencji planu produkcji (nieplanowane promocje, brak opakowań materiałowych oraz surowców, awaria maszyn) oraz niepoprawne dane w systemie SAP ERP. Liczne awarie systemu generują konieczność manualnego tworzenia dokumentów przewozowych, co zwiększa ryzyko popełnienia pomyłek (czynnik ludzki). Należy również zwrócić uwagę na przypadki późnego zgłoszenia zlecenia transportowego przez dział transportu przedsiębiorstwa, które najczęściej jest wynikiem nieprzewidzianych zamówień złożonych przez klienta. Przewoźnik powinien otrzymać zlecenie 2 dni przed planowaną realizacją usługi, a każde zapytanie złożone po godzinie 14:00 może zostać odrzucone lub spowoduje opóźnienie w dostarczeniu na czas samochodu pod załadunek. Kolejną przyczyną nieterminowych dostaw są ludzie. Częsta absencja pracowników oraz niewystarczająca wiedza o procesach magazynowych wydłuża czas załadunku, oraz wyładunku. Dodatkowo pośpiech może powodować pomyłkowe zamiany produktów pomiędzy naczepami i wysłanie ich do nieodpowiednich centrów dystrybucyjnych. Zwrot takich ładunków jest bardzo kosztowny oraz czasochłonny.

\section{Analiza procesu dystrybucji produktów tluszczowych przy użyciu metodyki TUL}

Przydatnym narzędziem do oceny czasu realizacji procesów związanych z transportem, przeładunkiem oraz magazynowaniem, jest analiza usług TUL (niem. Transport, Umschlag, Lagerung). Metoda pokazuje różnice czasowe pomiędzy planowanymi przez spedytora operacjami, a ich rzeczywistym czasem wykonania i pozwala określić, które czynności są najbardziej, a które najmniej czasochłonne [Sładkowski in. 2018]. Analizowany proces transportowy składa się z czterech głównych etapów: załadunek/wyładunek, transport, kontrola pojazdu oraz oczekiwanie na wydanie lub odebranie ładunku.

Realizacja badanej usługi rozpoczyna się w bazie transportowej przewoźnika. Pierwszym etapem jest odbiór wyrobu gotowego z zakładu produkcyjnego, a następnie odbywa się transport ładunku do centrum dystrybucyjnego przedsiębiorstwa (długość trasy prze-

Tabela 1. Analiza TUL dla badanej usługi transportowej - zestawienie zbiorcze

Table 1. TUL analysis for the examined transport service - summary

\begin{tabular}{|c|c|c|c|c|c|c|c|}
\hline \multirow{6}{*}{$\begin{array}{l}\text { Czynność: transport wyrobów } \\
\text { gotowych } \\
\text { Klient: badany zakład produkcyjny } \\
\text { Odbiorca: centrum dystrybucji } \\
\text { Przewoźnik: przedsiębiorstwo } \\
\text { transportowe }\end{array}$} & \multirow[b]{2}{*}{ Proces } & \multicolumn{2}{|c|}{ Rzeczywisty } & \multicolumn{2}{|c|}{ Planowany } & \multicolumn{2}{|c|}{ Różnica } \\
\hline & & 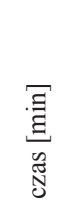 & 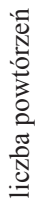 & 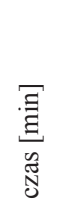 & 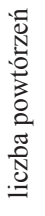 & 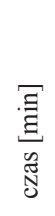 & 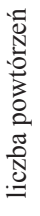 \\
\hline & załadunek/wyładunek & 242 & 2 & 180 & 2 & 62 & 0 \\
\hline & transport & 422 & 3 & 450 & 3 & -28 & 0 \\
\hline & kontrola pojazdu & 89 & 3 & 75 & 3 & 14 & 0 \\
\hline & oczekiwanie & 181 & 2 & 150 & 13 & 31 & 0 \\
\hline
\end{tabular}

Źródło: opracowanie własne na podstawie [Przybylska 2011, s. 248]. 
jazdu to około $154 \mathrm{~km}$ ). Przedmiotem przewozu jest 30 europalet wyrobów gotowych o łącznej wadze brutto $21897 \mathrm{~kg}$. Po wykonaniu usługi transportowej kierowca wraca do bazy transportowej swojej firmy.

W tabeli 1 przedstawiono sumaryczny czas trwania czynności, który zaobserwowano podczas wykonywania omawianej usługi.

W tabeli 2 wyszczególniono podział poszczególnych elementów procesu na czynności występujące podczas przewozu.

Tabela 2. Analiza TUL dla badanej usługi transportowej - zestawienie zbiorcze

Table 2. TUL analysis for the examined transport service - summary

\begin{tabular}{|c|c|c|c|c|c|c|c|c|c|c|c|}
\hline \multirow[b]{2}{*}{$\mathrm{Co} ?$} & \multirow[b]{2}{*}{ Gdzie? } & \multirow[b]{2}{*}{ Kto? } & \multirow[b]{2}{*}{ Jak? } & \multirow[b]{2}{*}{ Symbol } & \multirow[b]{2}{*}{ Opis } & \multirow{2}{*}{$\begin{array}{l}\text { Odle- } \\
\text { głość }\end{array}$} & \multirow{2}{*}{$\begin{array}{c}\text { Ilość } \\
{[\mathrm{t}]}\end{array}$} & \multicolumn{4}{|c|}{ Czas trwania [min] } \\
\hline & & & & & & & & $\square$ & $\Rightarrow$ & & \\
\hline $\begin{array}{c}\text { Ciągnik } \\
\text { siodłowy } \\
\text { z naczepą }\end{array}$ & $\begin{array}{l}\text { baza trans- } \\
\text { portowa }\end{array}$ & mechanik & $\begin{array}{l}\text { wizual- } \\
\text { nie }\end{array}$ & & $\begin{array}{l}\text { wzrokowa } \\
\text { kontrola } \\
\text { techniczna } \\
\text { pojazdu }\end{array}$ & & & 23 & & & \\
\hline $\begin{array}{l}\text { Ciągnik } \\
\text { siodłowy } \\
\text { z naczepą }\end{array}$ & $\begin{array}{l}\text { baza trans- } \\
\text { portowa }\end{array}$ & kierowca & $\begin{array}{l}\text { samo- } \\
\text { chód }\end{array}$ & & $\begin{array}{c}\text { opuszczenie } \\
\text { bazy }\end{array}$ & $60 \mathrm{~km}$ & & & 38 & & \\
\hline $\begin{array}{c}\text { Ciągnik } \\
\text { siodłowy } \\
\text { z naczepą }\end{array}$ & $\begin{array}{l}\text { parking } \\
\text { przedsię- } \\
\text { bior-stwa }\end{array}$ & kierowca & $\begin{array}{l}\text { samo- } \\
\text { chód }\end{array}$ & & $\begin{array}{l}\text { oczekiwanie } \\
\text { na załadunek }\end{array}$ & & & & & & 139 \\
\hline $\begin{array}{l}\text { Ciągnik } \\
\text { siodłowy } \\
\text { z naczepą }\end{array}$ & $\begin{array}{c}\text { rampa za- } \\
\text { ładunkowa } \\
\text { magazyn }\end{array}$ & $\begin{array}{l}\text { magazy- } \\
\text { nier }\end{array}$ & $\begin{array}{c}\text { wózek } \\
\text { widłowy }\end{array}$ & & $\begin{array}{l}\text { załadunek } \\
\text { towaru }\end{array}$ & $19 \mathrm{~m}$ & 22 & & & 200 & \\
\hline $\begin{array}{c}\text { Ciągnik } \\
\text { siodłowy } \\
\text { z naczepą }\end{array}$ & $\begin{array}{c}\text { rampa za- } \\
\text { ładunkowa } \\
\text { magazyn }\end{array}$ & $\begin{array}{c}\text { kierowca/ } \\
\text { magazy- } \\
\text { nier }\end{array}$ & $\begin{array}{l}\text { wizual- } \\
\text { nie }\end{array}$ & & $\begin{array}{l}\text { kontrola } \\
\text { załadunku }\end{array}$ & & 22 & 31 & & & \\
\hline $\begin{array}{c}\text { Ciągnik } \\
\text { siodłowy } \\
\text { z naczepą }\end{array}$ & & kierowca & $\begin{array}{l}\text { samo- } \\
\text { chód }\end{array}$ & & przewóz & $154 \mathrm{~km}$ & 22 & & 196 & & \\
\hline $\begin{array}{c}\text { Ciągnik } \\
\text { siodłowy } \\
\text { z naczepą }\end{array}$ & $\begin{array}{l}\text { parking } \\
\text { centrum } \\
\text { dystrybu- } \\
\text { cyjne }\end{array}$ & kierowca & $\begin{array}{l}\text { samo- } \\
\text { chód }\end{array}$ & & $\begin{array}{l}\text { oczekiwanie } \\
\text { na } \\
\text { rozładunek }\end{array}$ & & 22 & & & & 42 \\
\hline $\begin{array}{c}\text { Ciągnik } \\
\text { siodłowy } \\
\text { z naczepą }\end{array}$ & $\begin{array}{l}\text { centrum } \\
\text { dystrybu- } \\
\text { cyjne }\end{array}$ & $\begin{array}{l}\text { magazy- } \\
\text { nier }\end{array}$ & $\begin{array}{c}\text { wózek } \\
\text { widłowy }\end{array}$ & & $\begin{array}{c}\text { rozładunek } \\
\text { towaru }\end{array}$ & $18 \mathrm{~m}$ & 22 & & & 42 & \\
\hline $\begin{array}{c}\text { Ciągnik } \\
\text { siodłowy } \\
\text { z naczepą }\end{array}$ & $\begin{array}{l}\text { baza trans- } \\
\text { portowa }\end{array}$ & kierowca & $\begin{array}{l}\text { samo- } \\
\text { chód }\end{array}$ & & $\begin{array}{l}\text { powrót do } \\
\text { bazy }\end{array}$ & $146 \mathrm{~km}$ & & & 188 & & \\
\hline \multirow[t]{2}{*}{$\begin{array}{c}\text { Ciągnik } \\
\text { siodłowy } \\
\text { z naczepą }\end{array}$} & $\begin{array}{l}\text { baza trans- } \\
\text { portowa }\end{array}$ & mechanik & $\begin{array}{c}\text { narzę- } \\
\text { dzia }\end{array}$ & & $\begin{array}{l}\text { kontrola } \\
\text { techniczna } \\
\text { pojazdu }\end{array}$ & & & 35 & & & \\
\hline & & & & & SUMA & 360 & 22 & 89 & 422 & 242 & 181 \\
\hline
\end{tabular}

Gdzie: - kontrola, - transport,

- operacja (wyładunek, załadunek),

- oczekiwanie.

Źródło: opracowanie własne na podstawie [Przybylska 2011, s. 248]. 
Dokonana analiza pozwala zaobserwować, które czynności w procesie wykonywania usługi transportowej są najbardziej czasochłonne i wpływają na nieterminową dostawę. W badanym przypadku najwięcej czasu zajmuje transport, który stanowi $45 \%$ całkowitej usługi. Należy jednak pamiętać, że czas transportu to element zależny od czynników losowych, takich jak warunki pogodowe lub utrudnienia w ruchu. Czas załadunku i wyładunku oraz czas oczekiwania na obsługę zajmują odpowiednio 26 i 20\% rzeczywistego czasu wykonanej usługi i na tych elementach warto skoncentrować uwagę. Wprowadzenie zmian w obu etapach pozwoliłoby na zwiększenie punktualności dostaw i oszczędność czasu kierowcy.

\section{Podsumowanie i wnioski}

Badania na temat wybranych aspektów dystrybucji produktów tłuszczowych w działalności firmy branży FMCG pozwoliły zweryfikować pozytywnie hipotezę badawczą, że zastosowanie instrumentarium zarządzania łańcuchem dostaw w przedsiębiorstwie przyczynia się do usprawnienia jego funkcjonowania. Ponadto można sformułować następujące wnioski:

- dystrybucja, w zależności od jej konfiguracji i sprawności ma wpływ nie tylko na relację z klientem, ale również bezpośrednio na produkt i jego fizyczne właściwości;

- firmy produkujące towary tłuszczowe zwracają szczególną uwagę na to, by czas transferu do klienta był jak najkrótszy ze względu wrażliwy charakter wyrobu i reakcję produktów na czynniki zewnętrzne;

- istnieje wiele narzędzi zarządzania łańcuchem dostaw wspomagających proces dystrybucji w przedsiębiorstwach produkcyjnych. Ich stosowanie umożliwia poznanie struktury procesów, identyfikację zakłóceń, ich redukcję lub ograniczenie ich wpływu;

- zrozumienie schematów powiązań organizacyjnych i sekwencji czynności składających się na proces oraz występujących problemów, umożliwia rozpoznanie w przedsiębiorstwie obszarów wymagających doskonalenia i wskazanie propozycji usprawnień.

\section{Literatura}

Bozarth C., Handfield R., 2007: Wprowadzenie do zarządzania operacjami i łańcuchem dostaw, Wyd. Helion, Gliwice.

Encyklopedia Zarządzania, hasło: Strategia pull, [źródło elektroniczne] https://mfiles.pl/pl/index. php/Strategia_pull [dostęp: 25.02.2019].

Murphy P., Wood D., 2010: Nowoczesna logistyka, Wyd. Helion, Gliwice.

Peppard J., Rowland P., 1997: Re-engineering, Wyd. Gebethner i Ska, Warszawa.

Przybylska E., 2011: Analiza usługi transportowej w wybranym przedsiębiorstwie sektora TSL, Zeszyty Naukowe Politechniki Śląskiej 56, 245-249.

Rutkowski K. (red.), 2008: Najlepsze praktyki w zarządzaniu łańcuchem dostaw. Wyjść naprzeciw wyzwaniom społecznej odpowiedzialności biznesu, SGH, Warszawa.

Rutkowski K., 2005: Logistyka dystrybucji. Specyfika. Tendencje rozwojowe. Dobre praktyki, SGH, Warszawa. 
Sładkowski A., Cieśla M., Krupa B., 2018: Evaluation of Transport Processes Quality with Servqual and TUL Method, LOI - Scientific Journal on Transport and Logistics 9, 63.

Witkowski J., 2010: Zarządzanie łańcuchem dostaw, PWE, Warszawa.

Adresy do korespondencji:

dr hab. Maria Michalowska, prof. honorowy UE

(https://orcid.org/0000-0001-7421-3322)

Górnośląska Wyższa Szkoła Handlowa im. Wojciecha Korfantego w Katowicach

Wydział Zarządzania

ul. Harcerzy Września 1939 3, 40-659 Katowice

e-mail: Maria.Michalowska@gwsh.pl

inż. Nina Wielgórska

ul. Krasińskiego 47/2, 41-300 Dąbrowa Górnicza

e-mail: ninawielgorska@gmail.com 


\title{
Ekonomika i Organizacja Logistyki \\ 4 (2), 2019, 81-88
}

DOI: 10.22630/EIOL.2019.4.2.16

\section{Marcin Rabe}

\section{Uniwersytet Szczeciński}

\section{Rozwój i konkurencyjność transportu towarów koleją w Polsce \\ Development and competitiveness of rail transport in Poland}

\begin{abstract}
Synopsis. Infrastruktura jest jednym z dwunastu filarów konkurencyjności gospodarek. Infrastruktura kolejowa jako jeden z zasadniczych podstaw konkurencyjności jest swoistego rodzaju kręgosłupem gospodarki, dlatego jest tak ważna dla zapewnienia efektywnego funkcjonowania i rozwoju gospodarki. Celem opracowania jest ukazanie barier rozwoju transportu towarów koleją w Polsce. W artykule przedstawiono stan transportu kolejowego w Polsce oraz analizę założeń Projektu Strategii Zrównoważonego Rozwoju Transportu do 2030 roku. Projekt ten zakłada w latach 2015-2030 wzrost transportu drogowego minimum o $196 \mathrm{mln}$ t, a wzrost transportu kolejowego minimum o $30 \mathrm{mln}$ t, czyli o 6,5 razy mniej niż transport samochodowy. Wyniki badań w opracowaniu przedstawione zostały metodą opisową wspartą tabelaryczną prezentacją danych. Zrównoważenie kosztów infrastruktury kolejowej z infrastrukturą samochodową jedynie w niedużym stopniu może poprawić rozwój i konkurencyjność kolei. Nieodzowne jest więc podjęcie takich działań niezwiązanych z opłatami w transporcie kolejowym, które poprawią konkurencyjność transportu kolejowego względem transportu samochodowego.
\end{abstract}

Słowa kluczowe: transport kolejowy, przewozy ładunków

\begin{abstract}
Infrastructure is one of the twelve pillars of competitiveness of economies. Railway infrastructure as one of the basic foundations of competitiveness is a kind of backbone of the economy, which is why it is so important for ensuring effective functioning and development of the economy. The aim of the study is to show barriers to the development of transport of goods by rail in Poland. The article presents the state of railway transport in Poland and the analysis of the assumptions of the Sustainable Transport Development Strategy Project until 2030. This project assumes an increase in road transport by a minimum of 196 million tons in 2015-2030, and rail transport increases by at least 30 million tons in 2015-2030, which is 6.5 times less than in road transport. The research results presented in the study were conducted using a descriptive method supported by tabular data
\end{abstract}


presentation. Balancing the costs of railway infrastructure with car infrastructure can only slightly improve the development and competitiveness of railways. Therefore, it is indispensable to undertake such activities unrelated to rail transport charges, which will improve the competitiveness of rail transport in relation to road transport.

Key words: railway transport, cargo transport

\section{Wstęp}

Współczesny rynek usług kolejowych stoi przed wyzwaniem, jak odpowiedzieć na wzrastające potrzeby klientów w zakresie jakości świadczonych usług, stawiając jednocześnie czoła transportowi samochodowemu. Dostęp do funduszy unijnych programów regionalnych oraz strategia rozwoju kolei w Europie przyczynia się do wzrostu zamówień na prace związane z całą infrastrukturą kolejową. Stan infrastruktury kolejowej decyduje o jakości życia ludności, przejmując ładunki z innych rodzajów transportu. W projekcie Strategii Zrównoważonego Rozwoju Transportu do 2030 roku skierowanego do konsultacji przez Ministerstwo Infrastruktury z dnia 9 listopada 2018 roku występuje zapis dotyczący optymalizacji działania multimodalnych łańcuchów logistycznych, m.in. poprzez większe wykorzystanie bardziej energooszczędnych środków transportu. Jednym z tych środków transportu może okazać się kolej.

Celem opracowania jest ukazanie barier rozwoju transportu towarów koleją w Polsce spełniających potrzeby klientów w zakresie jakości świadczonych usług transportowych. Materiałem wykorzystanym w analizie były dane Głównego Urzędu Statystycznego, zestawienia i sprawozdania przygotowywane przez urząd transportu kolejowego, jak również Projekt Strategii Zrównoważonego Rozwoju Transportu do 2030 roku. Przy opracowaniu wyników zastosowano metodę opisową wspartą tabelaryczną prezentacją danych. W artykule wskazane są bariery, jakie powinny zostać pokonane, żeby transport kolejowy był konkurencyjny w stosunku do transportu samochodowego.

\section{Definicja transportu kolejowego}

Jednym z najważniejszych obszarów działania transportu jest przewóz osób i towarów. Dostawy towarów odbywają się za pomocą różnych środków transportu. Przy ich wyborze bierze się pod uwagę szybkość, częstotliwość, niezawodność, dostęp oraz koszt. Wybór środka transportu ma duży wpływ na cenę produktów, terminową dostawę do odbiorcy oraz na stan towarów po przetransponowaniu. Przegląd literatury pozwala określić różne znaczenie i zastosowanie pojęcia transportu. Tarski podkreśla klasyczną rolę, jaką odgrywa transport i określa go jako ,proces technologiczny wszelkiego przenoszenia na odległość, czyli przemieszczanie osób przedmiotów lub energii” [Tarski 1993].

Według Neidera [2008] transport jest świadczeniem usług polegających na przemieszczaniu ładunków lub usług dodatkowych bezpośrednio z tym związanych. Transport jest pojęciem szerokim i obejmującym wiele czynności, dzięki którym ładunek dotrze z miejsca nadania do miejsca docelowego. 
W ramach transportu świadczona jest usługa zwana przewozem. Czynności wykonywane w punktach transportowych, wraz z przewozem, tworzą pojęcie przemieszczania się towarów. Ładunek w trakcie przemieszczania obsługiwany jest za pomocą urządzeń technicznych, a dostarczenie towaru do punktu przeznaczenia wymaga zastosowania różnego rodzaju usług dodatkowych, takich jak np. usługi logistyczne, spedycyjne, celne, kontrolne itp. Wszystkie te elementy tworzą pojęcie transportu [Raczyński 2007].

Przez transport kolejowy definiuje się gałąź transportu lądowego, która polega na przemieszczaniu ludzi oraz ładunków za pomocą odpowiednich środków transportu kolejowego. Poprzez środki transportu kolejowego, rozumiemy lokomotywy oraz wagony [Szymonik 2014].

Główną cechą transportu kolejowego, wpływającą na organizację zadań przewozowych w tej gałęzi transportu, jest to, że może być on określony jako system autonomiczny, inteligentny i adaptacyjny [Krawczyk 2011].

Przewozy wykonywane transportem kolejowym są zdominowane przez ładunki masowe. Przeważają tutaj tradycyjne towary, takie jak: węgiel, ruda żelaza, zboża, nawozy, wyroby stalowe, materiały budowlane, produkty przetwarzania ropy naftowej. Stanowią one ponad 90\% wszystkich ładunków obsługiwanych przez transport kolejowy [Neider 2015].

Kwestie związane z prowadzeniem ruchu kolejowego w Polsce reguluje Ustawa z dnia 28 marca 2003 roku o transporcie kolejowym. Według niej działalność gospodarcza polegająca na wykonywaniu przewozów kolejowych podlega licencjonowaniu. Licencja taka jest ważna również na terenie innych państw Unii Europejskiej i wydawana jest bezterminowo [Ustawa o transporcie kolejowym..., 2003].

W Białej księdze ${ }^{1}$ wydanej w 2011 roku przez Komisję Europejską stwierdzono, że do 2030 roku 30\% drogowego transportu towarów na odległościach większych niż $300 \mathrm{~km}$ należy przenieść na inne środki transportu, np. kolej lub transport wodny, a do 2050 roku powinno to być ponad 50\% tego typu transportu. W Białej księdze dodano, że aby ten cel został spełniony, musi nastąpić rozbudowa stosownej infrastruktury oraz zachowanie gęstej sieci kolejowej we wszystkich państwach członkowskich, a także stworzenie do 2030 roku w pełni funkcjonalnej, ogólnounijnej, multimodalnej sieci bazowej TEN-T, a do 2050 roku osiągnięcie wysokiej jakości i przepustowości tej sieci, jak również stworzenie odpowiednich usług informacyjnych [Guszczak 2014].

Wprowadzenie rozwiązań systemowych może doprowadzić do wyrównania warunków konkurencyjności kolei z innymi gałęziami transportu, w tym przede wszystkim z transportem samochodowym. Aby wymagania te zostały spełnione, niezbędne jest pokonanie rozmaitych barier, które aktualnie występują na rynku kolejowym [Antonowicz 2017].

\section{Transport przewozów ladunków}

Stopień rozwoju infrastruktury transportowej jest istotnym czynnikiem lokalizacji rodzajów działalności lub sektorów, które mogą rozwijać się w poszczególnych regionach. Rozwoju infrastruktury zmniejsza poniekąd odległości między regionami i korzystnie

\footnotetext{
${ }^{1}$ Plan utworzenia jednolitego europejskiego obszaru transportu - dążenie do osiągnięcia konkurencyjnego i oszczędnego zasobowo systemu transportu.
} 
oddziałuje na jedność rynku krajowego oraz włącza go w system gospodarki światowej. Przy tym jakość infrastruktury ma znaczący wpływ na wzrost gospodarczy, likwidację ubóstwa, a jej ułomność może stać się „wąskim gardłem” w rozwoju państwa [Koźlak 2010].

Obecnie, rynek kolejowy przewozów towarowych w Polsce różni się od rynków innych krajów w Europie. W tej chwili na rynku w kraju znajduje się 60 przewoźników. Największymi przewoźnikami obecnie są PKP Cargo, DB Cargo Polska i Lotos Kolej. W 2015 roku udział w rynku tych trzech przedsiębiorstw wynosił 90\%. Hegemonia tych spółek spadła w 2016 roku do około 80\% rynku, a w 2017 roku wynosiła łącznie tylko $68 \%$ rynku. Spadek wynika z faktu pozyskania zleceń na transport ładunków koleją przez mniejsze firmy.

Spółka PKP Cargo jest największym w Polsce oraz czwartym co do wielkości w Unii Europejskiej operatorem kolejowych przewozów towarowych. Udział w rynku przewozu towarów koleją w 2017 roku w zestawieniu według masy ładunków wynosił 44,2\%.

Analizując lata 2010-2011, nastąpił wzrost masy przewiezionych ładunków o $13.9 \mathrm{mln}$ ton, dotyczy to także pracy przewozowej i eksploatacyjnej. W latach 2012-2015 to okres redukcji masy przewiezionych ładunków o 9,5 $\mathrm{mln} \mathrm{t}$ (tab. 1).

Tabela 1. Masa przewiezionych ładunków w Polsce w latach 2010-2015

Table 1. Mass of transported loads in Poland in 2010-2015

\begin{tabular}{|c|c|c|c|}
\hline Rok & $\begin{array}{c}\text { Masa przewiezionych ladunków } \\
{[\mathrm{mln} \mathrm{t}]}\end{array}$ & $\begin{array}{c}\text { Praca przewozowa } \\
{[\mathrm{mld} \mathrm{tkm}]}\end{array}$ & $\begin{array}{c}\text { Praca eksploatacyjna } \\
{[\text { mln pociągokilometrów] }}\end{array}$ \\
\hline 2010 & 235,3 & 48,8 & 71,5 \\
\hline 2011 & 249,2 & 54,0 & 79,3 \\
\hline 2012 & 234,3 & 51,1 & 74,4 \\
\hline 2013 & 233,2 & 50,9 & 74,3 \\
\hline 2014 & 228,9 & 50,1 & 74,9 \\
\hline 2015 & 224,8 & 50,6 & 74,8 \\
\hline
\end{tabular}

Źródło: [Marcysiak i Marcysiak 2018].

W 2017 roku transportem kolejowym przewieziono ogółem 239,5 mln t ładunków, tj. o 7,6\% więcej niż w 2016 roku, a praca przewozowa osiągnęła poziom 54,8 mld tkm i była większa o $8,2 \%$. Przewozy manewrowe wyniosły $15,4 \mathrm{mln}$ ton (o $28,9 \%$ mniej) oraz 0,10 mld tkm (o 34,0\% mniej) [Antonowicz 2017]. Poziom przewozów ładunków mierzony tonokilometrami lokuje polski transport kolejowy na drugim miejscu wśród 28 krajów Unii Europejskiej, za Niemcami, a przed Francją [GUS 2018].

Średnia odległość przewozu jednej tony ładunku zwiększyła się w latach 2016-2017 z 222 do 229 km. Na rynku nadal dominowały przewozy ładunków takich jak węgiel kamienny, ropa naftowa, rudy metali oraz produkty górnictwa i kopalnictwa [Marcysiak i Marcysiak 2018]. W tabeli 2 przedstawiono dynamikę przewozu ładunków w 2017 roku w Polsce.

W ramach transportu intermodalnego transportem kolejowym przewieziono o 14,6\% kontenerów więcej niż w 2016 roku, przy czym w większym stopniu zwiększyła się liczba kontenerów w komunikacji międzynarodowej o 22,2\% niż w komunikacji krajowej o $0,3 \%$. Udział komunikacji międzynarodowej w liczbie przewiezionych kontenerów wzrósł z 64,9\% w 2016 roku do 69,3\% w 2017 roku. 
Tabela 2. Dynamika przewozy ładunków 2017 roku

Table 2. Dynamics of cargo transport 2017

\begin{tabular}{|c|c|c|c|c|}
\hline \multirow{2}{*}{ Wyszczególnienie } & \multirow{2}{*}{2016} & \multirow{2}{*}{2017} & \multicolumn{2}{|c|}{2017} \\
\hline & & & $2015=100$ & $2016=100$ \\
\hline Przewozy ładunków [tys. t] & 1836652 & 2053244 & 113,8 & 111,8 \\
\hline Transport kolejowy & 222523 & 239501 & 106,8 & 107,6 \\
\hline Transport samochodowy & 1546572 & 1747266 & 116,0 & 113,0 \\
\hline w tym zarobkowy & 954459 & 1104209 & 123,8 & 115,7 \\
\hline w tym przedsiębiorstwa transportu samochodowego & 761160 & 867816 & 123,1 & 114,0 \\
\hline Transport rurociągowy & 54058 & 52393 & 95,5 & 96,9 \\
\hline Transport morski & 7248 & 8254 & 118,5 & 113,9 \\
\hline Śródlądowy transport wodny & 6210 & 5777 & 48,4 & 93,0 \\
\hline Transport lotniczy & 41 & 53 & 140,0 & 127,2 \\
\hline Przewozy ładunków (mln tkm) & 385678 & 434932 & 120,6 & 112,8 \\
\hline Transport kolejowy & 50650 & 54797 & 108,3 & 108,2 \\
\hline Transport samochodowy & 303560 & 348559 & 127,6 & 114,8 \\
\hline w tym zarobkowy & 261560 & 302259 & 130,1 & 115,6 \\
\hline w tym przedsiębiorstwa transportu samochodowego & 228631 & 258677 & 128,5 & 113,1 \\
\hline Transport rurociągowy & 22204 & 21080 & 96,5 & 94,9 \\
\hline Transport morski & 8242 & 9362 & 73,5 & 113,6 \\
\hline Śródlądowy transport wodny & 832 & 877 & 40,1 & 105,4 \\
\hline Transport lotniczy & 190 & 257 & 164,6 & 134,7 \\
\hline
\end{tabular}

Źródło: [GUS 2018].

Masa przewiezionych ładunków w 2017 roku w kontenerach była większa o 17,0\% niż w 2016 roku. Liczba przewiezionych nadwozi samochodowych swap body zwiększyła się o 27,0\%, a liczba naczep ciężarowych była zmniejszyła się o 40,9\%. Udział masy ładunków transportu intermodalnego w 2007 roku w ogólnej masie ładunków przewiezionych transportem kolejowym wyniósł 6,1\%, a w 2016 roku wyniósł 5,7\% [GUS 2018].

Długość sieci kolejowej ogółem w 2017 roku wyniosła 19,2 tys. km i była o 77 km dłuższa niż przed rokiem. Sieć PKP wydłużyła się o $84 \mathrm{~km}$, a sieć kolejowa zarządzana przez inne podmioty skróciła się o 4 km do 271 km. W ogólnej długości linii kolejowych eksploatowanych normalnotorowych i szerokotorowych linie zelektryfikowane stanowity $61,7 \%$.

W 2017 roku zostało zmodernizowanych 902 km torów, w tym 457 km torów na liniach dostosowanych do prędkości 120-160 km [GUS 2018] .

\section{Bariery hamujące rozwój konkurencyjność transportu kolejowego}

Przedstawione wcześniej wyniki badań prowadzone były metodą opisową, wspartą tabelaryczną prezentacją danych. Pomimo że wyniki badań z roku na rok są coraz lepsze, nie mogą być jednak w pełni satysfakcjonujące. Udział przewozów ładunków na rynku kolejowym powinien być zdecydowanie większy. 
Projekt Strategii Zrównoważonego Rozwoju Transportu do 2030 roku zakłada w latach 2015-2030 wzrost transportu drogowego minimum o $196 \mathrm{mln} \mathrm{t}$, a transportu kolejowego o $30 \mathrm{mln} \mathrm{t}$, czyli o 6,5 razy mniej niż transport samochodowy. W wersji maksymalnej projekt zakłada wzrost transportu samochodowego o 7,5 razy więcej niż transport kolejowy. Ograniczeniami rozwoju transportu kolejowego są rozmaite bariery takie jak:

- zła jakoś usług kolejowych, do których zaliczyć należy:

- długi czas przejazdu,

- częste opóźnienia w przewozach,

- długi czas postoju pociągów na stacjach granicznych,

- brak konkurencyjności cenowej transportu kolejowego w odniesieniu do transportu drogowego, która charakteryzuje się przede wszystkim wysokimi:

- frachtami kolejowymi,

- cenami za usługi przeładunkowe,

- cenami za dowozy, odwozy kontenerów.

- brak centrów logistycznych powodujący rozproszenie potoku ładunków,

- brak kompleksowych i efektywnych instrumentów promujących przewozy kolejowe w ramach polityki transportowej państwa,

- mała skuteczność dotychczasowych instrumentów promujących przewozy ładunków transportem kolejowym,

- niedostatecznie dobry stan techniczny linii kolejowych.

Dlatego właściwe jest wdrożenie rozwiązań systemowych, które wyrównałyby warunki konkurencyjności kolei z innymi gałęziami transportu, w tym przede wszystkim $\mathrm{z}$ transportem samochodowym i powinno to nastąpić poprzez:

- relewantne zwiększenie wsparcia publicznego do zarządzania i utrzymania infrastruktury kolejowej, co spowoduje obniżkę stawek dostępu do infrastruktury kolejowej;

- eskalację systemu opłat za dostęp do infrastruktury transportu drogowego na całą sieć dróg krajowych;

- wzrost wsparcia publicznego dla przedsiębiorstw świadczących usługi kombinowanego transportu drogowo-kolejowego poprzez ulgę intermodalna do opłaty za dostęp do infrastruktury kolejowej;

- wdrożenie trwałych w dłuższym okresie, możliwie niskich stawek za dostęp do infrastruktury dla przewozów intermodalnych i zróżnicowania marż zarządcy infrastruktury.

Niebagatelnym problemem przewozów ruchu mieszanego drogowo-kolejowego i kolejowo-drogowego jest przepustowość linii kolejowych, która ogranicza prędkość handlową pociągów towarowych. W gronie możliwych posunięć ulepszających konkurencyjność transportu kolejowego względem transportu drogowego, niezwiązanych z opłatami, znajdują się:

1. Polepszanie dostępności terminali intermodalnych poprzez budowę nowych terminali i wprowadzanie innowacyjnych technologii skracających do minimum czas przeładunku.

2. Wzrost skuteczności zarządzania infrastrukturą kolejową poprzez automatyzację sterowania ruchem kolejowym. 
3. Wzrost szybkości handlowej przewozów towarowych poprzez przebudowę kierowania ruchu kolejowego oraz inwestycje zwiększające przejezdność infrastruktury kolejowej.

4. Udoskonalenie praktyk związanych z przydzielaniem tras i alokacją możliwości przepustowej w transporcie kolejowym.

5. Zaopatrzenie taboru kolejowego w elektroniczne identyfikatory pozwalające śledzenie.

6. Poprawa i automatyzacja procesów związanych z rozrządem wagonów w świetle oczekiwanego podwyższenia przewozów rozproszonych

7. Usunięcie barier administracyjnych $\mathrm{w}$ transporcie kolejowym.

8. Dofinansowywanie środkami publicznymi utrzymywania regularnych towarowych połączeń kolejowych na niektórych trasach.

9. Wdrożenie systemu rekompensat za niepokryte koszty środowiskowe związane z wypadkami i infrastrukturą.

\section{Podsumowanie i wnioski}

Lista czynników hamujących rozwój transportu kolejowego jest obszerna. Należą do nich między innymi wysokie koszty dostępu do infrastruktury kolejowej, która jest jednym z dwunastu filarów konkurencyjności gospodarek. Infrastruktura kolejowa jako jeden z zasadniczych podstaw konkurencyjności jest swoistego rodzaju kręgosłupem gospodarki, dlatego jest tak ważna dla zapewnienia efektywnego funkcjonowania i rozwoju gospodarki. Zrównoważenie kosztów infrastruktury kolejowej z samochodową jedynie w niedużym stopniu poprawi konkurencyjność kolei. Zakładając, że dostęp do infrastruktury kolejowej będzie darmowy, prawdopodobnie cena frachtu kolejowego spadłaby nie więcej niż o $20 \%$. Niestety jest to zbyt mało, żeby transport kolejowy mógł skutecznie konkurować z transportem drogowym na większości tras. Wdrożenie niskich stawek w dłuższym czasie za dostęp do infrastruktury dla przewozów intermodalnych jest prawdopodobny pod warunkiem uwypuklenia przez zarządcę infrastruktury segmentów rynku przewozowego i zróżnicowania marz zarządcy infrastruktury.

Analiza wielkości przewozów na rynku kolejowym w Polsce wykazała także aspekty pozytywne. W 2017 roku w zakresie przewozów towarowych nastąpiła znacząca poprawa. Transportem kolejowym przewieziono ogółem 239,5 mln t ładunków, tj. o 7,6\% więcej niż w 2016 roku, a praca przewozowa osiągnęła poziom 54,8 mld tonokilometrów i była większa o $8,2 \%$. Średnia odległość przewozu jednej tony ładunku zwiększyła się w latach 2016-2017 z $222 \mathrm{~km}$ do $229 \mathrm{~km}$.

Projekt Strategii Zrównoważonego Rozwoju Transportu do 2030 roku zakłada wzrost transportu samochodowego minimum o 6,5 razy więcej niż transport kolejowy. Wersji maksymalnej Projekt zakłada wzrost transportu samochodowego o 7,5 razy więcej niż transport kolejowy.

Nieodzowne jest podjęcie w takim razie szerszych działań ulepszających efektywność i jakość usług w transporcie kolejowym. Transport kolejowy i kombinowany boryka się z wieloma problemami obniżających konkurencyjność, które nie występują w transporcie drogowym. Usunięcie barier pozwoliłoby przedsiębiorstwom zdecydowanie chętniej i częściej korzystać z tej formy, jakim jest transport kolejowego. 


\section{Literatura}

Antonowicz M., 2017: Kolej musi wpisywać się w założenia polityki zrównoważonego rozwoju, Kurier Kolejowy, 26 października 2017, [źródło elektroniczne] https://www.kurierkolejowy. eu/aktualnosci/31096/kolej-musi-wpisywac-sie-w-zalozenia-polityki-zrownowazonegorozwoju.html [dostęp: 26.02.2019].

GUS, 2018: Transport - wyniki działalności w 2017 r., Warszawa - Szczecin.

Guszczak B., 2014: Rozwój transportu kolejowego w Polsce na przestrzeni ostatnich lat, Logistyka 3, 2294-2203

Koźlak A., 2010: Ekonomika transportu, teoria i praktyka gospodarcza, Wydawnictwo Uniwersytetu Gdańskiego, Gdańsk.

Krawczyk S., 2011: Logistyka. Teoria i Praktyka. Tom I, Difin, Warszawa.

Marcysiak A, Marcysiak A. 2018: Zmiany na rynku przewozów kolejowych w Polsce, Zeszyty Naukowe Uniwersytetu Przyrodniczo-Humanistycznego w Siedlcach 116, 125-138.

Neider J., 2008: Transport międzynarodowy, PWE, Warszawa.

Neider J., 2015: Transport międzynarodowy, PWE, Warszawa.

Raczyński, J., 2007: Kolejowe przewozy towarowe a megaciężarówki, TTS Technika Transportu Szynowego 10, 24-26.

Szymonik, A., 2014: Eurologistyka Teoria i Praktyka, Difin, Warszawa.

Tarski I., 1993: Ekonomika i organizacja transportu międzynarodowego, PWE, Warszawa.

Ustawa o transporcie kolejowym z dnia 28 marca 2003 r. (Dz.U. z 2003 r., nr 86, poz. 789).

Adres do korespondencji:

dr Marcin Rabe

(https://orcid.org/0000-0002-4817-1971)

Uniwersytet Szczeciński

Wydział Zarządzania i Ekonomiki Usług

Katedra Logistyki

Centrum Zarządzania w Energetyce ul. Cukrowa 8, 71-004, Szczecin e-mail: marcin.rabe@wzieu.pl 


\title{
Ekonomika i Organizacja Logistyki \\ 4 (2), 2019, 89-98
}

DOI: 10.22630/EIOL.2019.4.2.17

\author{
Elżbieta Jadwiga Szymańska1, Edyta Workowska \\ ${ }^{1}$ Szkoła Główna Gospodarstwa Wiejskiego w Warszawie
}

\section{Podsystemy zaopatrzenia i dystrybucji w gospodarstwach trzodowych o różnej skali produkcji \\ Supply and distribution subsystems on pig farms with various production scale}

\begin{abstract}
Synopsis. Celem badań było rozpoznanie rozwiązań logistycznych w gospodarstwach o różnej skali produkcji żywca wieprzowego. Szczegółową analizą objęto podsystemy zaopatrzenia i dystrybucji w czterech gospodarstwach specjalizujących się w tuczu trzody chlewnej. Z badań wynika, że gospodarstwa trzodowe tworzą systemy logistyczne, które ze względu skalę produkcji i stopień specjalizacji różnią się w zakresie zaopatrzenia i dystrybucji. Małe gospodarstwa mają mniejszą szansę na długotrwałą współpracę z przedsiębiorstwami mięsnymi, a duże nie zawsze chcą wiązać się długoterminowymi kontraktami z ubojniami. Do najważniejszych problemów funkcjonowaniu gospodarstw trzodowych należą zmienne warunki pogodowe, wahania cen oraz zwiększająca się liczba przepisów. Trudności sprawia także pozyskanie pozwoleń na rozbudowę budynków inwentarskich. Największe jednak zagrożenie stanowi rozprzestrzeniający się w Polsce od 2014 roku wirus afrykańskiego pomoru świń (ASF).
\end{abstract}

\begin{abstract}
The aim of the research was to identify logistic solutions on farms with various scale of live pig production. The detailed analysis covered supply and distribution subsystems on four farms specializing in pig fattening. Research shows that pig farms create logistics systems that, due to the scale of production and the degree of specialization, differ in terms of supply and distribution. Small farms have less chance of long-term cooperation with meat enterprises and large farms do not always want to involve long-term contracts with slaughterhouses. The most important problems in the functioning of pig farms include changing weather conditions, price fluctuations and an increasing number of regulations. Obtaining permits for the expansion of livestock buildings is also difficult. However, the biggest threat is the African swine fever virus (ASF), which has been spreading in Poland since 2014.
\end{abstract}

Słowa kluczowe: system logistyczny, gospodarstwo rolnicze, żywiec wieprzowy, podsystem zaopatrzenia, kanały dystrybucji

Key words: logistics system, farms, live pigs, supply subsystem, distribution channels 


\section{Wprowadzenie}

System logistyczny to celowo zorganizowany i zintegrowany w obrębie danego układu gospodarczego przepływ materiałów i produktów oraz odpowiadających im informacji, umożliwiających optymalizację w zarządzaniu łańcuchami dostaw [Abt 2000]. Inaczej jest to sieć organizacji, osób, działań, informacji i zasobów zaangażowanych w fizyczny przepływ produktów od dostawcy do klienta [Fahimnia i in., 2011]. Dobrze zorganizowany, dostosowany do współczesnych wyzwań i wymagań system logistyczny jest nie tylko szansą, ale wręcz wymogiem czasów, gdy procesy związane z wymianą towarową stają się coraz bardziej złożone, zwiększa się ich skala, a konieczność dostosowania się do potrzeb i wymagań nabywców idzie w parze z przymusem obniżki kosztów, by sprostać konkurencji na rynkach. W ramach systemu logistycznego funkcjonują wszystkie gospodarstwa rolnicze. Ze względu jednak na ich zróżnicowanie, tworzone przez nich systemy mogą być bardzo proste lub złożone. To zależy między innymi od wielkości gospodarstwa, kierunku i struktury produkcji oraz poziomu specjalizacji [Kiperska-Moroń i Krzyżaniak 2002]. W wąskim ujęciu działania w systemie gospodarstwa rolniczego koncentrują się na przepływach materiałów i produktów oraz towarzyszących im informacji wewnątrz podmiotu. Na podstawie czynności realizowanych w poszczególnych fazach systemu można wyodrębnić [Blaik 1996]:

- podsystem zaopatrzenia - przepływ surowców, materiałów od dostawców do magazynów zaopatrzeniowych lub bezpośrednio na produkcję;

- podsystem produkcji - przepływ surowców, materiałów, półfabrykatów, wyrobów gotowych i części zamiennych między magazynami zaopatrzeniowymi i magazynami wyrobów gotowych;

- podsystem dystrybucji - przepływ wyrobów gotowych pomiędzy magazynami dystrybucyjnymi i klientami na rynku zbytu lub bezpośrednio z produkcji do klientów.

Główne podsystemy wspomagane są przez transport i magazynowanie, które pojawiają się przekrojowo na każdym szczeblu systemu (rys. 1).

W ujęcia szerokim gospodarstwo rolnicze jako system obejmuje przepływy surowców, materiałów i produktów oraz informacji między współpracującymi ze sobą podmiotami na rynku zaopatrzenia i dystrybucji. W ten sposób stanowi jedno z ogniw w łańcuchu dostaw żywności [Motowidlak 2009], który obejmuje wiele działań i procesów produkcyjnych, przetwórczych, magazynowych oraz dystrybucyjnych. Zaczyna się od producentów pasz, czy też innych produktów pierwotnych, poprzez producentów żywności, usługodawców transportu i magazynowania, a kończy na strefie zbytu produktów. Ponadto uwzględnia także producentów maszyn i urządzeń oraz wytwórców opakowań i składników dodatkowych [Dobrowolski i in. 2016]. Ogniwa, które wchodzą w skład każdego łańcucha dostaw żywności, przedstawiono na rysunku 2.

Gospodarstwo specjalizujące się chowie trzody chlewnej również tworzy specyficzny dla danego kierunku produkcji system logistyczny. Chów trzody chlewnej może być prowadzony na dwa zasadnicze sposoby, w cyklu zamkniętym lub otwartym. Pierwszy z nich polega na tym, że w gospodarstwie utrzymywane są wszystkie grupy technologiczne trzody chlewnej, a produktem końcowym są tuczniki. Drugi oznacza specjalizację w jednym lub w dwóch etapach cyklu produkcyjnego. Najczęściej jest to chów loch, gdzie końcowym produktem są prosięta, albo tuczarnia, w której tuczy się zakupione prosięta lub warchlaki. W literaturze funkcjonuje także pojęcie cyklu mieszanego, który 


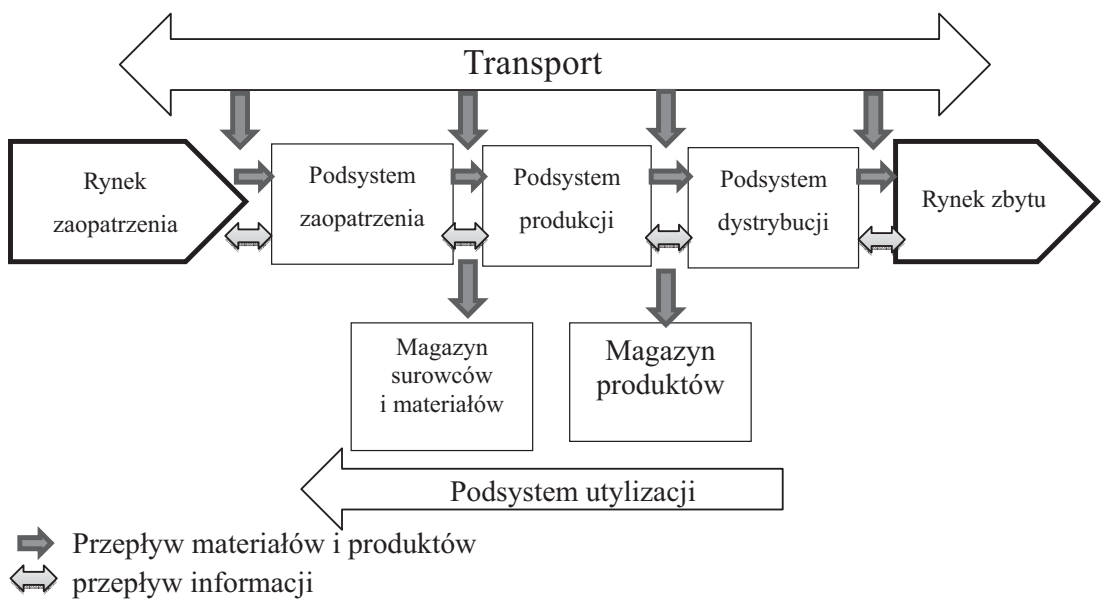

Rysunek 1. Gospodarstwo rolne jako system logistyczny

Figure 1. Farm as a logistics system

Źródło: opracowanie własne.

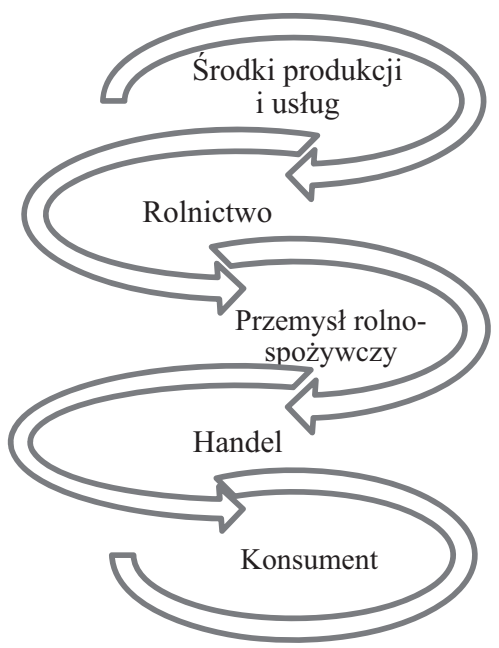

Rysunek 2. Ogniwa łańcucha żywnościowego

Figure 2. Food chain links

Źródło: opracowanie własne.

polega na utrzymywaniu wszystkich grup technologicznych w gospodarstwie, ale część materiału do produkcji pochodzi z zakupu [Szymańska 2011]. Wyboru cyklu chowu dokonuje się po przeanalizowaniu warunków, jakimi dysponuje gospodarstwo w zakresie pomieszczeń, własnej bazy paszowej, możliwości zakupu koniecznych pasz, nakładów pracy, odległości i chłonności rynku oraz aktualnych cen. 


\section{Cel i metodyka badań}

Celem badań było rozpoznanie rozwiązań logistycznych w gospodarstwach o różnej skali produkcji żywca wieprzowego. Szczegółową analizą objęto podsystemy zaopatrzenia i dystrybucji. Te dwa podsystemy szczególnie wskazują na powiązania gospodarstw z rynkiem i determinują ich sytuację ekonomiczną. System zaopatrzenia jednego podmiotu jest najczęściej działem zbytu/dystrybucji drugiego podmiotu i odwrotnie, dlatego też funkcjonują one na podobnych zasadach. W opracowaniu postawiono hipotezę, że skala produkcji oddziałuje na organizację podsystemu zaopatrzenia i dystrybucji w gospodarstwach trzodowych.

Badania przeprowadzono w czterech gospodarstwach ${ }^{1}$ o różnej wielkości utrzymywanych stad, które prowadziły produkcję zwierzęcą i roślinną, jednak w ich strukturze przychodów dominowała sprzedaż żywca wieprzowego. Wszystkie gospodarstwa realizowały produkcję w systemie otwartym, który polegał na tuczu zakupionych prosiąt lub warchlaków. Analizowane gospodarstwa znajdują się w województwie łódzkim, które zajmuje trzecią pozycję pod względem wielkości pogłowia trzody chlewnej w kraju. Taki dobór obiektów pozwolił na zaobserwowanie rozwiązań w gospodarstwach o podobnej lokalizacji geograficznej. W badaniach wykorzystano metodę studiów przypadków i analizę porównawczą. Cennym źródłem informacji była także literatura przedmiotu. W celu pozyskania danych empirycznych z gospodarstw trzodowych w każdym z nich przeprowadzono wywiad kierowany $\mathrm{z}$ właścicielem danego podmiotu.

\section{Systemy zaopatrzenia w badanych gospodarstwach}

Podsystem zaopatrzenia w gospodarstwie rolnym ma za zadanie dostarczyć odpowiednie surowce i materiały do produkcji. Ze względu na system chowu badane gospodarstwa zaopatrywały się w warchlaki od innych gospodarstw albo przedsiębiorstw. Najmniejsze z badanych gospodarstw kupowało około 300 sztuk warchlaków w ciągu roku, a największe prawie 30 razy więcej (tab. 1). Kolejnym niezbędnym produktem w gospodarstwach trzodowych były pasze. Gospodarstwa w Karnicach i w Lakowie stosowały system żywienia mieszankami własnej produkcji. Pozostałe dwa gospodarstwa kupowały pasze. Mniejsze gospodarstwa rolne produkowały pasze ze swoich zbóż, a na rynku pozyskiwały jedynie dodatki paszowe. Większe, ze względu na skalę produkcji musiały kupować nie tylko dodatki paszowe, ale również zboża. Gospodarstwo z Lakowa, przeznaczając pod uprawę zbóż około 50 ha, przy średnim plonie około 5-6 t/ha, produkowało $250 \mathrm{t}$ ziarna na rok. Z zakupu natomiast pochodziło prawie 2-krotnie więcej zbóż. Z kolei gospodarstwo zlokalizowane w Bleszynie rocznie było w stanie wyprodukować około 500 t ziarna zbóż. Biorąc pod uwagę wielkość produkcji żywca wieprzowego, musiało ono dokupić prawie 2,5-razy więcej ziarna.

W celu ograniczenia kosztów produkcji rolnicy starali się kupować potrzebne surowce i materiały w okresach niskich cen. W przypadku ziarna zbóż najniższe ceny występowały od sierpnia do września. Wynikało to ze zwiększonej podaży zbóż po zbiorach. Ponadto, w tym okresie na sprzedaż decydowali się producenci, którzy uprawiali zboża, a nie

\footnotetext{
${ }^{1}$ Ze względu na ochronę danych nazwy miejscowości zmieniono.
} 
Tabela 1. Środki do produkcji kupowane przez badane gospodarstwa w ciągu roku

Table 1. Production inputs bought by farms during the year

\begin{tabular}{|l|c|c|c|c|}
\hline Nazwa surowca & Karnice & Natolin & Laków & Bleszyn \\
\hline Materiał hodowlany (prosięta/warchlaki) [szt.] & 300 & 1350 & 3600 & 9000 \\
\hline Pasze [t] & 0 & 286 & 0 & 750 \\
\hline Zboże [t] & 0 & 0 & 500 & 1200 \\
\hline Dodatki paszowe [t] & 10 & 13,5 & 120 & 250 \\
\hline Materiał siewny (ziarno zbóż, kukurydzy, sadzeniaki ziemniaków) [t] & 0,5 & 3 & 5 & 10 \\
\hline $\begin{array}{l}\text { Nawozy (wieloskładnikowe, azotowe, fosforowe, potasowe, } \\
\text { wapniowe) [t] }\end{array}$ & 1 & 8 & 25 & 50 \\
\hline Środki ochrony roślin & + & + & + & + \\
\hline Leki & + & + & + & + \\
\hline Nośniki energii (olej napędowy, węgiel, prąd elektryczny) & + & + & + & + \\
\hline Materiały budowlane (np. cegła, cement, betoniarka) & + & + & + & + \\
\hline Maszyny i urządzenia (ciągniki, wodociągi) & + & + & + & + \\
\hline $\begin{array}{l}\text { Drobny sprzęt, ubrania robocze (widły, taczki, kombinezony, } \\
\text { buty gumowe) }\end{array}$ & + & + & + & + \\
\hline Części zamienne & + & + & + & + \\
\hline Opieka weterynaryjna & + & + & + & + \\
\hline
\end{tabular}

Źródło: badania własne.

posiadali odpowiednich magazynów. Wraz z wydłużaniem się okresu przechowywania ziarna jego cena wzrastała. Rolnicy chcąc pokryć koszty magazynowania oraz strat naturalnych, sprzedawali surowiec po wyższej cenie.

Wahania cen w skali roku zaobserwowano także na rynku nawozów. W badanych gospodarstwach nawozy kupowano zazwyczaj w czerwcu, gdy cena była najniższa, np. w lutym 2019 roku rolnik musiał zapłacić o około 300 PLN/t więcej niż w czerwcu 2018 roku. Inaczej sytuacja wygląda z materiałem hodowlanym kupowanym przez gospodarstwa. By zachować ciągłość produkcji po skończeniu jednego okresu tuczu, rolnicy zaczynają następny. $\mathrm{W}$ takiej sytuacji nie mają wpływu na cenę warchlaków i są zmuszeni kupować młode zwierzęta po aktualnie występującej cenie rynkowej.

Wszystkie badane obiekty zaopatrywały się również w materiał siewny, nawozy mineralne, środki ochrony roślin, nośniki energii i leki. Ponadto kupowały materiały budowlane, maszyny i urządzenia oraz drobny sprzęt. W celu realizacji produkcji wszystkie obiekty badawcze korzystały z usług weterynaryjnych, utylizacji padłych zwierząt oraz serwisów maszyn (tab. 2). Oprócz tego w najmniejszym gospodarstwie wynajmowało także usługodawcę do koszenia zboża oraz prasowania słomy. Usługi tego rodzaju są bardzo popularne, zwłaszcza w mniejszych obszarowo gospodarstwach.

W zakresie zaopatrzenia największy wpływ na produkcję żywca wieprzowego ma dobrej jakości materiał hodowlany. Z danych wynika, że długoletnia współpraca z jednym dostawcą może być korzystana dla kooperujących podmiotów. Najmniejsze gospo- 


\section{E.J. Szymańska, E. Workowska}

Tabela 2. Usługi realizowane $\mathrm{w}$ badanych gospodarstwach $\mathrm{w}$ ciągu roku

Table 2. Services provided in the surveyed farms during the year

\begin{tabular}{|l|c|c|c|c|}
\hline Nazwa usługi & Karnice & Natolin & Laków & Błeszyn \\
\hline Usługi weterynaryjne & + & + & + & + \\
\hline Usługi utylizacji padłych zwierząt & + & + & + & + \\
\hline Serwis maszyn & + & + & + & + \\
\hline Prasowanie słomy & + & - & - & - \\
\hline Koszenie zboża & + & - & - & - \\
\hline
\end{tabular}

Źródło: badania własne.

darstwo rolne zlokalizowane w Karnicach od 2014 roku współpracuje w tym zakresie z firmą Agro-TransHandel Sp. z o.o.. Benefitem tych powiazań jest możliwość zakupu materiału hodowlanego na podstawie faktury o przedłużonym terminie płatności (rys. 3). Gospodarstwa położone w Natolinie oraz w Lakowie od 2013 roku współpracują z firmą Agri Plus Sp. z o.o. W 2018 roku to przedsiębiorstwo wprowadziło możliwość zakupu warchlaków na kredyt u współpracującego banku. Takie rozwiązanie sprawia, producenci żywca wieprzowego mają możliwość odroczenia terminu zapłaty za materiał hodowlany, a zakłady mięsne utrzymują ciągłość produkcji. Inne korzyści współpracy z dostawcami warchlaków w badanych gospodarstwach przedstawiono na rysunku 3. We wszystkich badanych gospodarstwach dostawca udzielał pomocy finansowej rolnikom. Ponadto, dla trzech mniejszych gospodarstw organizował i dostarczał pasze lub dodatki paszowe. Właściciele współpracujących z przedsiębiorstwem gospodarstw mogli również brać udział w szkoleniach organizowanych przez dostawcę oraz korzystać z doradztwa w za-

Dostawca udziela pomocy finansowej (np.: kredyty, przedłużoneone terminy spłat)

Dostawca prosiąt organizuje pasze

Doradztwo w zakresie organizacji produkcji organizowanej przez dostawcę

Udział w szkoleniach organizowanych przez dostawcę

Dostawca organizuje zbyt tuczników

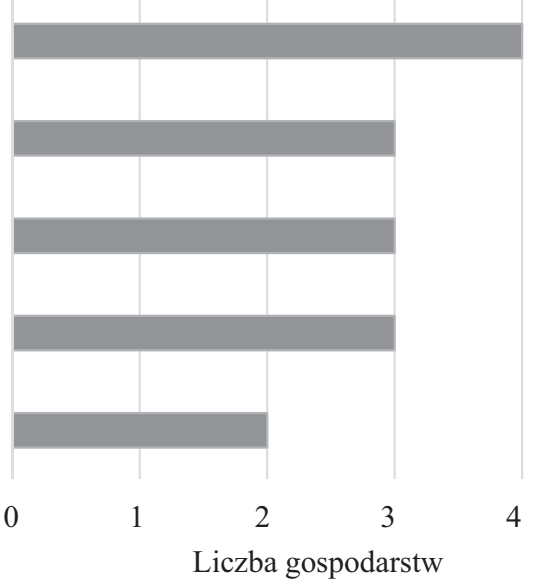

Rysunek 3. Zakres współpracy badanych gospodarstw z dostawcami

Figure 3. The scope of cooperation between the surveyed farms and suppliers

Źródło: badania własne. 
kresie organizacji produkcji. Występujące powiązania i zakres współpracy między przedsiębiorstwem a rolnikami były zatem dość szerokie. Producenci żywca wieprzowego nie otrzymywali natomiast pomocy zootechnicznej i żadne z gospodarstw nie było na tyle silne, by firma zaopatrzeniowa dzieliła się z nim wypracowanymi zyskami.

\section{Kanały dystrybucji tuczników w analizowanych gospodarstwach}

Badane gospodarstwa większość przychodów uzyskiwały ze sprzedaży żywca wieprzowego. Jednak odbiorcy tuczników byli różni, pod względem skali uboju oraz formy współpracy. Gospodarstwo rolne z Karnic zwykle sprzedawało wyprodukowany żywiec wieprzowy do małej lokalnej ubojni w Ziewanicach. Rolnik zobowiązany był dostarczać tuczniki o odpowiedniej wadze od $115 \mathrm{~kg}$ do $130 \mathrm{~kg}$. Cenę za żywiec ustalano na podstawie wagi żywej. Gospodarstwa położone w Natolinie oraz Lakowie współpracowały na zasadzie umowy kontraktacyjnej z firmą Agri Plus Sp. z o.o. Gospodarstwa te są silnie zintegrowane z tym przedsiębiorstwem, które jest zarówno dostawcą warchlaków, jak i odbiorcą tuczników. Żywiec wieprzowy dostarczany do ubojni tej firmy musi cechować się odpowiednią jakością i mięsnością (z przedziału 87,5-97,5 kg), a cena ustalana jest dopiero po uboju. Inny sposób dystrybucji występował w gospodarstwie zlokalizowanym w Błeszynie. Gospodarstwo to nie było powiązane z firmami przetwórczymi i przy sprzedaży tuczników rolnik kierował się aktualną ceną na rynku. Odbiorcami tuczników z tego gospodarstwa były najczęściej duże ubojnie i przetwórnie, ale także pośrednicy i małe lokalne ubojnie. Cena była zwykle ustalana za wagę żywą trzody chlewnej.

Dwa średnie obiekty badawcze ściśle współpracowały z jedną firmą zarówno w procesie zaopatrzenia, jak i dystrybucji. Od 2013 roku kooperowały z przedsiębiorstwem Agri Plus Sp. z o.o. na zasadzie umów kontraktacyjnych. Za najważniejszą przyczynę kontraktacji właściciele obu gospodarstw wskazali stabilizację produkcji, poprzez dostawy prosiąt i możliwość zbytu tuczników, a także ich terminowość tych działań (tab. 3). Wśród innych przesłanek wymieniano wysoką jakość, dużych partii prosiąt. Pozytywnie oceniono także możliwość udziału w szkoleniach oraz doradztwo w zakresie organizacji produkcji.

Umowa kontraktacyjna obejmuje także negatywne aspekty, głównie związane z ceną zakupu prosiąt i sprzedaży trzody chlewnej. Cena zapisana w umowie, a ustalona kilka miesięcy wcześniej czasami jest niższa od rynkowej i producenci żywca wieprzowego nie mogą jej zmienić. Oprócz tego niewielka siła przetargowa producentów tuczników może przyczynić się do zawarcia niekorzystnej umowy. Ponadto, w wywiadach wskazano negatywny wpływ wydłużonych terminów płatności ze strony przedsiębiorstwa oraz możliwość wystąpienia kar za niedotrzymanie warunków umowy.

Producenci żywca wieprzowego, którzy nie zawarli umów kontraktacyjnych, zaznaczyli, iż w głównej mierze spowodowane było to koniecznością sprzedaży tuczników po określonej cenie. Z kolei właściciel gospodarstwa o najmniejszej skali produkcji zwrócił uwagę, że wielkość jego produkcji jest niewystarczająca, by zainteresować zakłady mięsne stałą współpracą. Kluczowy był także fakt wahających się cen na rynku żywca wieprzowego oraz argument niewywiązywania się przez przedsiębiorstwa z zapisów zawartych w umowie. 


\section{Problemy w rozwoju gospodarstw trzodowych}

Każdy podmiot gospodarczy na rynku musi rozwiązywać różnego rodzaju problemy. Badane gospodarstwa musiały radzić sobie przede wszystkim z trudnościami wynikającymi z warunków pogodowych oraz ze zmiennością cen na rynku. Dla wszystkich gospodarstw trzodowych w Polsce od 2014 roku duże zagrożenie stanowi rozprzestrzeniający się wirus afrykańskiego pomoru świń (ASF). Niepewność co do dalszego rozwoju choroby skutkowała wstrzymaniem inwestycji w badanych gospodarstwach. Poważnym problemem dla właścicieli gospodarstw była także pogłębiająca się biurokratyzacja oraz trudności w pozyskaniu pozwoleń na rozbudowę budynków inwentarskich. Zwiększająca się liczba przepisów oraz nakaz identyfikacji stad wymusza zwiększenie nakładów pracy administracyjnej, a w przypadku niedopilnowania tego obszaru gospodarstwa są karane i ponoszą straty finansowe. Oprócz tego część przepisów zdaniem właścicieli nie była przystosowana do zmieniających się warunków klimatycznych. Przykładem może być zaostrzenie norm stosowania nawozów mineralnych. Skrócenie czasu ich używania spowodowało sytuację, że przy dość wysokiej temperaturze w początkowych miesiącach roku, rozpoczęła się wegetacja roślin, ale przepisy blokowały możliwość stosowania nawozów. To negatywnie wpłynęło na produkcję roślinną. Ponadto, w ostatnich latach w Polsce można zaobserwować zwiększające się ceny surowców i materiałów, co przyczynia się do zmniejszania opłacalności produkcji. Z kolei występujące coraz częściej anomalie pogodowe niszczą uprawy, zmniejszając podaż produktów roślinnych, czego przykładem może być produkcja zbóż w 2018 roku. Powoduje to duże wahania cen na rynku trzody chlewnej, niepewność produkcji oraz zmienność opłacalności.

Dla gospodarstwa położonego we wsi Karnice znaczącym problemem była także mała powierzchnia użytków rolnych i związana z tym ograniczona skala produkcji. Skutkowało to niewielkimi obrotami i brakiem inwestycji. W wyniku tej sytuacji gospodarstwo posiadało ubogie zaplecze maszynowe oraz cechowało się niskim stopniem mechanizacji pracy. Wymiana przestarzałych maszyn i urządzeń wiązałaby się z bardzo wysokimi nakładami środków finansowych. Jednak dalsza rozbudowa gospodarstwa oraz zaangażowanie środków wydawało się bezcelowe w przypadku braku zainteresowaniem dzieci rolnika do przejęcia produkcji.

Właściciel gospodarstwa zlokalizowanego w Natolinie także zwracał uwagę na niewystarczającą powierzchnię UR, która powodowała konieczność stosowania droższych mieszanek paszowych z zakupu. Jednak niepewność co do opłacalności produkcji wstrzymuje dalsze inwestycje w tym zakresie. Problemem dla gospodarstwa były także zmiany w kontraktach z firmą dostarczającą warchlaki, która wprowadziła konieczność kredytowania zakupów. Z jednej strony wydawało się to dobrym rozwiązaniem, jednak z drugiej podnosiło cenę jednostkową kupowanych zwierząt.

Wymienione problemy dotyczyły również, przynajmniej częściowo, gospodarstwa położonego w Lakowie. Ponadto, właściciel tego podmiotu zauważył także negatywną postawę sąsiadów w przypadku chęci rozbudowy budynków inwentarskich. Blokowanie inwestycji przez okolicznych rolników wydłużyło proces rozbudowy gospodarstwa o około 4 lata. Kolejne inwestycje musiały być przez rolnika bardzo szczegółowo zaplanowane.

Gospodarstwo zlokalizowane w Błeszynie także borykało się z częścią problemów dotykających pozostałe obiekty badawcze. Dodatkowo położone jest ono w okolicy, którą można nazwać ,zagłębiem trzodowym”, co wpływa na konieczność radzenia sobie 
z konkurencją. Skutkuje to także rywalizacją o cenę surowców do produkcji, chociażby ziarna zbóż czy nawozów organicznych. Taka lokalizacja ma jednak także swoje dobre strony, między innymi liczne przykłady dobrej produkcji zwierzęcej.

\section{Wnioski}

1. Przeprowadzone badania potwierdziły, że gospodarstwa rolnicze, zwłaszcza wyspecjalizowane w produkcji żywca wieprzowego tworzą systemy logistyczne. Ze względu jednak na różną skalę produkcji i stopień specjalizacji systemy te różnią się w zakresie zaopatrzenia, dystrybucji i powiązań z otoczeniem.

2. Do najważniejszych pozycji w zakresie zaopatrzenia w gospodarstwach trzodowych wyspecjalizowanych w tuczu trzody chlewnej należy zakup odpowiedniej liczby prosiąt lub warchlaków o wysokich walorach genetycznych. W przypadku małej powierzchni użytków rolnych istotnym elementem zaopatrzenia jest także zakup zbóż i/albo gotowych mieszanek paszowych w zależności od systemu żywienia.

3. Badane obiekty cechowały różne systemy dystrybucji tuczników. Gospodarstwo o najmniejszej skali produkcji sprzedawało zwierzęta do małej lokalnej ubojni. Dwa większe gospodarstwa współpracowały zarówno przy dostawie prosiąt, jak i zbycie tuczników z międzynarodową firmą w ramach umów kontraktacyjnych. Największy producent żywca wieprzowego dywersyfikował kanały dystrybucji w celu pozyskania wyższych cen sprzedaży.

4. W opracowaniu potwierdzono hipotezę, że skala produkcji oddziałuje na organizację podsystemu zaopatrzenia i dystrybucji w gospodarstwach trzodowych. $Z$ reguły duże przedsiębiorstwa mięsne nie są zainteresowane współpracą z małymi gospodarstwami. Z kolei gospodarstwa o dużej skali produkcji nie zawsze chcą wiązać się długoterminowymi kontraktami z ubojniami. Dzięki swojej sile przetargowej wykorzystują szansę negocjacji cen na rynku, aby obniżyć koszty zakupów i uzyskać wyższe przychody z tytułu sprzedaży tuczników.

5. Producenci żywca wieprzowego muszą radzić sobie z różnymi z trudnościami. Do najważniejszych należą zmienne warunki pogodowe i wahania cen na rynku. Ponadto, zwiększająca się liczba przepisów oraz nakaz identyfikacji stad wymusza zwiększenie nakładów na prace administracyjne. Trudności sprawia także pozyskanie pozwoleń na rozbudowę budynków inwentarskich. Od 2014 roku największe zagrożenie dla funkcjonowania gospodarstw trzodowych w Polsce stanowi rozprzestrzeniający się wirus afrykańskiego pomoru świń (ASF).

\section{Literatura}

Abt S., 2000: Specyfika logistyki ponad granicami, [w:] S. Abt (red.), Logistyka ponad granicami, Biblioteka Logistyka, Poznań.

Blaik P., 1996: Logistyka. Koncepcje zintegrowanego zarządzania przedsiębiorstwem. Polskie Wydawnictwo Ekonomiczne, Warszawa.

Dobrowolski D., Marciniak A., Łojewski Z., Bartnik G., 2016: Technologie semantyczne w zarządzaniu łańcuchami żywności, [źródło elektroniczne] http://www.ptzp.org.pl/files/ konferencje/kzz/artyk_pdf_2016/T2/t2_0025.pdf [dostęp: 30.01.2019]. 
Fahimnia B., Molaei R., Hassan Ebrahimi M., 2011: Integration in Logistics Planning and Optimization, [w:] R. Farahani, S. Rezapour, L. Kardar (red.), Logistics Operations and Management, Concepts and Models, Elsevier Inc.

Kisperska-Moroń, D. i Krzyżaniak, S., 2009: Logistyka. Instytut Logistyki i Magazynowania, Poznań.

Motowidlak U., 2009: Aktywność gospodarstw rolnych w Polsce w budowaniu łańcuchów dostaw, Zeszyty Naukowe SGGW. Problemy Rolnictwa Światowego 8(23).

Szymańska E., 2011: Efektywność gospodarstw wyspecjalizowanych w produkcji żywca wieprzowego w Polsce, Wydawnictwo SGGW, Warszawa.

Adres do korespondencji:

Dr hab. inż. Elżbieta Jadwiga Szymańska, prof. SGGW

(https://orcid.org/0000-0001-7686-1243)

Szkoła Główna Gospodarstwa Wiejskiego

Wydział Nauk Ekonomicznych

Katedra Logistyki

ul. Nowoursynowska 166, 02-787 Warszawa

e-mail: elzbieta_szymanska@sggw.pl 


\title{
Ekonomika i Organizacja Logistyki \\ 4 (2), 2019, 99-106
}

DOI: 10.22630/EIOL.2019.4.2.18

\author{
Agnieszka Thuczak \\ Uniwersytet Opolski
}

\section{Równowaga długookresowa pomiędzy cenami w lańcuchu dostaw na rynku mleka

\author{
Long-term relation between prices
} in the supply chainon the milk market}

\begin{abstract}
Synopsis. Łańcuch dostaw żywności łączy działania, ze sfery pierwotnej produkcji rolnej (rolnika) aż do konsumenta. Obejmuje on producentów, dostawców, firmy transportowe, magazyny, sprzedawców hurtowych i detalicznych, organizacje usługowe oraz konsumentów. Poziomy cen w poszczególnych ogniwach łańcucha dostaw na rynku mleka, ale nie tylko, charakteryzują się cyklicznością. Celem artykułu jest zbadanie, na podstawie danych pochodzących z Głównego Urzędu Statystycznego, występowania długookresowych zależności pomiędzy cenami na rynku mleka w poszczególnych ogniwach łańcucha dostaw. W badaniach wspomnianych zależności pomocny będzie test na występowanie kointegracji Engle'a-Grangera. Zakres czasowy analiz obejmuje lata 2010-2019.
\end{abstract}

Słowa kluczowe: kointegracja, łańcuch dostaw żywności, rynek mleka

\begin{abstract}
The food supply chain combines actions whose primary aim is to ensure the satisfaction of buyers and the profit of enterprises participating in the flow of products and services from the sphere of primary agricultural production (farmer) to the consumer. It includes producers, suppliers, transport companies, warehouses, wholesale and retailers, service organizations and consumers. The price level in individual links of the supply chain in the milk market, but not only, is characterized by cyclicality. The aim of the article is to examine, on the basis of data from the Statistical Office, the occurrence of long-term relations between prices on the milk market in individual links of the supply chain. In studies of these relationships, the Engle-Granger cointegration test will be helpful. The time range of analyzes covers the years 2010-2019
\end{abstract}

Key words: cointegration, food supply chain, milk market

\section{Wstęp}

Produkcja rolna jak żadna inna działalność gospodarcza jest bardzo podatna na zmiany uwarunkowań, zarówno rynkowych, jak i przyrodniczych. Surowce rolnicze podlegają wielu procesom przetwórczym, zanim od rolnika (producenta) trafią do odbiorcy finalnego (konsumenta). Łańcuch dostaw żywności charakteryzuje się dużą różnorodnością 
podmiotów wchodzących w jego skład. Obejmuje on producentów, dostawców, firmy transportowe, magazyny, sprzedawców hurtowych i detalicznych, organizacje usługowe oraz konsumentów [Morkis i in. 2010, Tłuczak 2016].

Łańcuch dostaw żywności obejmuje sekwencję etapów i procesów odbywających się w produkcji, przetwórstwie, dystrybucji, magazynowaniu i postępowaniu z żywnością oraz jej składnikami, począwszy od produkcji pierwotnej aż do konsumpcji [Szymańska $\mathrm{i}$ in. 2018]. Postrzegany, jako całość, a nie wyodrębnione części, łańcuch dostaw pozwala w pełni efektywnie reagować na różnego typu sytuacje [Abt 2003, Jarzembowski 2013].

Pełne wykorzystanie potencjału łańcucha dostaw żywności jest zadaniem niełatwym i wynika ze złożoności występujących powiązań pomiędzy jego podmiotami. Uczestnikami wymiany w łańcuchu dostaw są bowiem jednocześnie podmioty o różnej wielkości, które występują w roli konkurentów, dostawców oraz klientów. Globalizacja i utworzenie jednolitego rynku europejskiego powodują, że podmioty międzynarodowe stanowią coraz poważniejszą konkurencję w poszczególnych ogniwach tego łańcucha [Motowidlak i Fajczak-Kowalska 2010].

Wahania cen w ciągu ostatnich lat, zarówno tych płaconych rolnikom, jak i tych płaconych przez konsumentów, dobitnie pokazały brak równowagi w łańcuchu dostaw. Jako główne przyczyny tego zachwiania wymienia się wzmożoną globalizację i koncentrację, zwłaszcza w sektorze detalicznym. Głównym skutkiem braku równowagi jest bardzo silna presja na obniżanie cen płaconych rolnikom. Rolnicy nie są w stanie samodzielnie pokryć kosztów produkcji ani nie mają środków na inwestycje, co prowadzi do zaniechania działalności oraz dużych opóźnień w inwestycjach i innowacjach [Tłuczak 2015, Promowanie..., 2019].

\section{Metodyka i dane źródłowe}

Głównym celem badań była identyfikacja długookresowych zależności pomiędzy cenami mleka w poszczególnych ogniwach łańcucha dostaw. Wyodrębnione ogniwa to:

- punkty skupu oferujące producentom rolnym cenę za mleko, które musi spełniać określone warunki;

- przetwórcy, którzy nabywają mleko z punktów skupu;

- detaliczne punkty sprzedaży, które oferują klientom przetworzony produkt.

Do weryfikacji hipotezy o występowaniu długookresowych zależności pomiędzy zmiennymi została wykorzystana analiza kointegracji szeregów czasowych. Koncepcja ta została wprowadzona przez Engle'a i Grangera w 1987 roku. Istota kointegracji zawiera się w możliwości wyznaczenia długookresowej ścieżki równowagi, niezależnej od czasu, pomiędzy badanymi zmiennymi [Przekota i Rembeza 2016].

Jeżeli podobieństwo zachowania zmiennych sugeruje istnienie relacji długookresowych, wtedy, chcąc zbudować model opisujący zarówno relacje krótko- i długookresowe, należy pozostać na poziomach zmiennych pierwotnych i odwołać się do koncepcji kointegracji. W tym celu poszukiwana jest taka kombinacja liniowa zmiennych niestacjonarnych, która będzie zintegrowana niższego rzędu. Znalezienie takiej kombinacji liniowej pozwala zbudować model, w którym współczynniki kointegrujące odzwierciedlają długookresowe relacje między badanymi zmiennymi, natomiast mechanizm korekty błędem uwzględnia procesy dostosowawcze [Mikołajczyk i Wyrobek 2006]. 
Hipoteza badawcza analizy kointegracji zakłada występowanie łącznego mechanizmu wyjaśniającego zmiany wartości cen krótko- i długookresowych w poszczególnych ogniwach łańcucha dostaw. Kointegracja szeregów czasowych dwóch zmiennych $\left(x_{t}, y_{t}\right)$ występuje, gdy są one zintegrowane w stopniu $d$, a ich liniowa kombinacja $-\beta_{1} x_{t}+\beta_{2} y_{t}$, jest zintegrowana rzędu $d-b(d \geq b \geq 0)$. Wektor $\left[\beta_{1}, \beta_{2}\right]$ nazywany jest wektorem kointegracyjnym. Zazwyczaj szeregi czasowe obserwacji na zmiennych są zintegrowane stopnia pierwszego, a ich liniowa kombinacja jest stacjonarna. Składowe wektora kointegracyjnego określają długookresowe wiązki pomiędzy zmiennymi [Batóg 2016]. Najczęściej wykorzystywaną procedurą testowania kointegracji jest dwu etapowa reguła Engle’a i Grangera. W pierwszym kroku za pomocą rozszerzonego testu Dickeya-Fullera ocenia się stacjonarność szeregów czasowych. Zaproponowany przez Dickeya-Fullera test zakłada w hipotezie zerowej, że badany szereg jest niestacjonarny z powodu występowania pierwiastka jednostkowego $\left(H_{0}: \delta=0\right)$. Hipoteza alternatywna mówi o stacjonarności szeregu $\left(H_{1}: \delta<0\right)$. Do przeprowadzenia testu potrzebna jest często zmodyfikowana wersja testu (ADF) daną relacją [Tłuczak 2011]:

$$
\Delta y_{t}=\mu+\delta y_{t-1}+\sum_{i=1}^{k} \delta \Delta y_{t-i}+e_{t} \quad \text { lub } \quad \Delta y_{t}=\delta y_{t-1}+\sum_{i=1}^{k} \delta_{i} \Delta y_{t-i}+e_{t}
$$

Decyzję o odrzuceniu bądź nie, hipotezy zerowej podejmuje się na podstawie statystyki DF liczonej za pomocą ilorazu t-Studenta:

$$
D F=\frac{\hat{\delta}}{S(\hat{\delta})}
$$

Jeżeli obliczona wartość statystyki DF jest większa niż wartość krytyczna, to nie ma podstaw do odrzucenia hipotezy zerowej o niestacjonarności badanego szeregu, w przeciwnym wypadku należy ją dorzucić [Borzyszkowska 2007].

Następnie przechodzi się do badania stacjonarności reszt modelu:

$$
\mathrm{y}_{\mathrm{t}}=\beta_{0}+\beta_{2} \mathrm{x}_{\mathrm{t}}+\varepsilon_{\mathrm{t}}
$$

gdzie:

$x_{t}$ i $y_{t}-$ to zmienne, których skointegrowanie jest badane;

$\beta_{0}$, i $\beta_{2}-$ to parametry strukturalne;

$\varepsilon_{t}-$ składnik losowy.

W przypadku stacjonarności reszt modelu stwierdzone zostaje, że zmienne $x_{t}$ i $y_{t}$ są skointegrowane. Występowanie kointegracji potwierdza istnienie trwałej, długookresowej relacji pomiędzy analizowanymi szeregami czasowymi [Tatarczak 2007].

\section{Wyniki badań}

Istotnym elementem analizy funkcjonowania łańcuchów dostaw żywności są występujące zależności pomiędzy cenami w poszczególnych ogniwach łańcucha, a w szczególności istnienia określonej relacji między nimi w długim okresie. Celem takiej analizy jest 
możliwość prognozowania cen na tym rynku i budowanie długoterminowych strategii funkcjonowania podmiotów. W niniejszym artykule podjęto się określenia długookresowych zależności pomiędzy cenami mleka w skupie, cenami producenta mleka oraz cenami detalicznymi mleka. Między poszczególnymi ogniwami występują powiązania integracyjne oraz sformalizowana i niesformalizowana współpraca, których celem jest tworzenie warunków harmonijnego przepływu dóbr, informacji i środków pieniężnych przez wyodrębnione ogniwa oraz płynny dopływ dóbr finalnych do konsumenta [Jarczyński 2003, Kapusta 2009].

W pracy wykorzystano metody wpisujące się w ekonometryczną analizę szeregów czasowych, w szczególności badanie relacji kointegrujących. Kointegracja oznacza długookresową zależność procesów ekonomicznych, którą interpretuje się jako ścieżkę równowagi ${ }^{1}$. Występowanie kointegracji między cenami w dwóch ogniwach łańcucha dostaw oznacza, że w długim okresie ceny te będą ze sobą silnie skorelowane, jednak w krótkim okresie może wystąpić tendencja odwrotna [Allen i MacDonald 1951].

Dane empiryczne wykorzystane w badaniu obejmują okres od stycznia 2010 roku do lutego 2019 roku. Są to średnie miesięczne nominalne ceny mleka w skupie (mleko_skup), ceny producenta (mleko_prod) oraz ceny detaliczne (mleko_detal) w Polsce, wyrażone w PLN za litr. Dane zgromadzono na podstawie informacji udostępnianych przez GUS. Na rysunku 1 przedstawiono kształtowanie się analizowanych zmiennych, na podstawie których zostały wyznaczone wybrane statystyki opisowe oraz współczynniki korelacji liniowej pomiędzy zmiennymi (tab. 1 i 2).

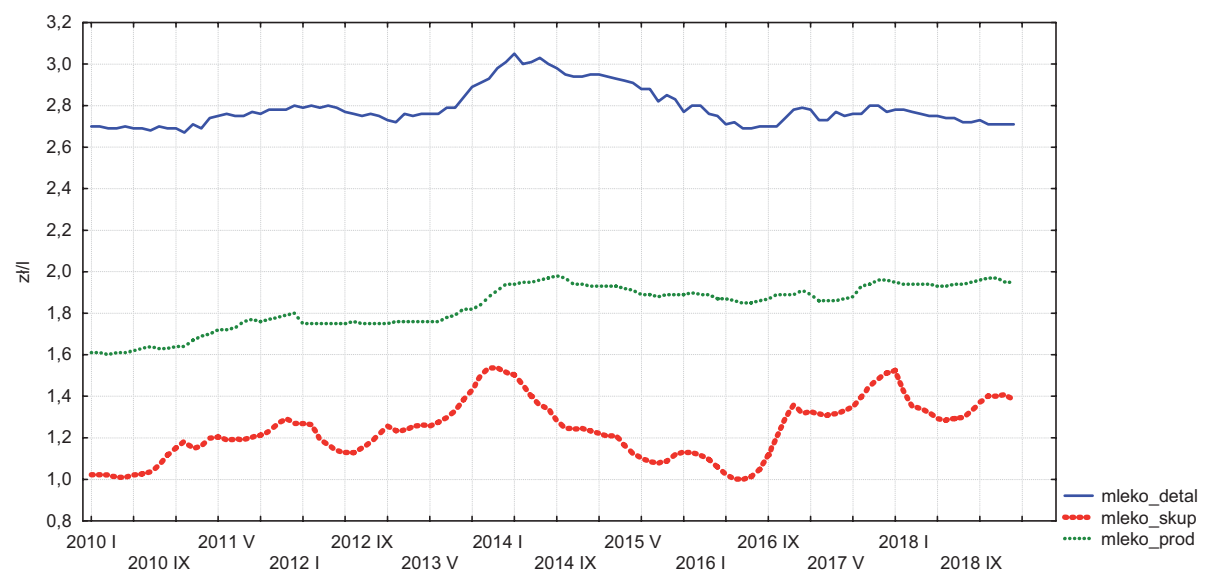

Rysunek 1 . Ceny mleka w skupie, ceny producentów mleka, ceny detaliczne mleka od stycznia 2010 do lutego 2019 (PLN/1).

Figure 1. Milk prices in procurement, prices of milk producers, retail milk prices from January 2010 to February 2019 (PLN/l).

Źródło: opracowanie własne na podstawie [GUS 2019].

\footnotetext{
${ }^{1}$ W krótkim okresie mogą wystąpić odchylenia od ścieżki równowagi, szerzej: Kośko M., Osińska M., Stempińska J., (red.), 2007: Ekonometria współczesna, TNOiK „Dom Organizatora”, Toruń, 313 i nast.
} 
Tabela 1. Statystyki opisowe cen mleka w skupie, cen producenta mleka i cen detalicznych mleka Table 1. Descriptive statistics of milk prices in procurement, milk producer prices and milk retail prices

\begin{tabular}{|c|c|c|c|c|}
\hline Zmienna & Średnia & Wsp. Zmienności (\%) & Skośność & Kurtoza \\
\hline mleko_skup & 1,240 & 11,2 & 0,179 & $-0,633$ \\
\hline mleko_prod & 1,834 & 5,9 & $-0,602$ & $-0,778$ \\
\hline mleko_detal & 2,789 & 3,3 & 1,152 & 0,372 \\
\hline
\end{tabular}

Źródło: opracowanie własne na podstawie [GUS 2019].

Tabela 2. Współczynniki korelacji pomiędzy zmiennymi

Table 2. Correlation coefficients

\begin{tabular}{|c|c|c|c|}
\hline & mleko_skup & mleko_prod & mleko_detal \\
\hline mleko_skup & 1 & 0,569 & 0,425 \\
\hline mleko_prod & 0,569 & 1 & 0,521 \\
\hline mleko_detal & 0,425 & 0,521 & 1 \\
\hline
\end{tabular}

Źródło: opracowanie własne na podstawie [GUS 2019].

W pierwszej kolejności sprawdzono stacjonarność analizowanych zmiennych, na podstawie uzyskanych wyników nie ma podstaw do odrzucenia hipotezy zerowej mówiącej o występowaniu pierwiastka jednostkowego. Oznacza to, że analizowane zmienne charakteryzują się brakiem stacjonarności. Wyniki rozszerzonego testu Dickeya-Fullera dla pierwszych różnic zmiennych wskazują, że badane szeregi są zintegrowane w stopniu pierwszym (tab. 3).

Tabela 3. Wyniki rozszerzonego testu Dickeya-Fullera dla zmiennych oraz dla pierwszych różnic Table 3. Results of the extended Dickey-Fuller test for variables and for the first differences

\begin{tabular}{|c|c|c|}
\hline Zmienna & Statystyka testu & Wartość $p$ \\
\hline mleko_skup & $-4,265$ & 0,349 \\
\hline mleko_prod & $-2,353$ & 0,405 \\
\hline mleko_detal & $-2,469$ & 0,344 \\
\hline d_mleko_skup & $-5,4339$ & 0,000 \\
\hline d_mleko_prod & $-5,3159$ & 0,000 \\
\hline d_mleko_detal & $-4,5259$ & 0,001 \\
\hline
\end{tabular}

Źródło: opracowanie własne na podstawie [GUS 2019].

Następnie oszacowano parametry trzech równań kointegrujących:

mleko_skup $=-0,476+0,964$ mleko_prod $+\varepsilon_{\mathrm{t}}$

mleko_prod $=0,153+0,546$ mleko_detal $+\varepsilon_{t}$

mleko_skup $=-0,529+0,598$ mleko_detal $+\varepsilon_{\mathrm{t}}$

na poziomie istotności $\alpha=0,05$ otrzymane wartości statystyk testowych wskazywały na istotność statystyczną otrzymanych parametrów. W kolejności ponownie za pomocą rozszerzonego testu Dickeya-Fullera zweryfikowano hipotezę zerową, mówiącą o występowaniu pierwiastka jednostkowego w procesie resztowym z otrzymanych równań. 
Tabela 4. Wyniki testu Engle'a -Grangera.

Table 4. Engle- Granger test results.

\begin{tabular}{|l|c|c|}
\hline Równanie & Statystyka testu & Wartość $p$ \\
\hline mleko_skup $=-0,476+0,964$ mleko_prod $+\varepsilon_{\mathrm{t}}$ & $-3,486$ & 0,102 \\
\hline mleko_prod $=0,153+0,546$ mleko_detal $+\varepsilon_{\mathrm{t}}$ & $-3,883$ & 0,048 \\
\hline mleko_skup $=-0,529+0,598$ mleko_detal $+\varepsilon_{\mathrm{t}}$ & $-3,607$ & 0,077 \\
\hline
\end{tabular}

Źródło: opracowanie własne na podstawie danych GUS.

Na podstawie otrzymanych wyników testu (tab.4) $(\alpha=0,05)$ można stwierdzić, że nie ma podstaw do odrzucenia hipotezy zerowej w przypadku równania 1 i 3, zatem reszty z tych równań kointegrujących nie są stacjonarne. Co oznacza, że nie występuje kointegracja między cenami skupu i cenami producenta, jak również nie występuję ona w przypadku cen skupu i cen detalicznych. W przypadku cen producenta i cen detalicznych stwierdza się niestacjonarność reszt równania kointegrującego (równanie 2), co za tym idzie te dwie zmienne, reprezentujące szeregi czasowe, są skointegrowane. Można wówczas mówić o występowaniu długookresowej zależności pomiędzy zmiennymi.

\section{Podsumowanie i wnioski}

Funkcjonowanie poszczególnych ogniw w łańcuchu dostaw żywności jest uzależnione od zmian, jakie mogą mieć miejsce w łańcuchach dostaw w gospodarce europejskiej. $\mathrm{Na}$ sytuację produkcyjno-ekonomiczną sektora rolno-spożywczego, w którego obrębie funkcjonuje łańcuch dostaw żywności w Polsce, wpływają m.in. wahania produkcji roślinnej i zwierzęcej, systematyczny wzrost cen środków produkcji oraz zmienna koniunktura na światowych rynkach. Działanie czynników strukturalnych oraz przejściowych powoduje spowolnienie dynamiki wzrostu produkcji w jednostkach powiązanych $\mathrm{z}$ łańcuchem dostaw żywności w stosunku do pozostałych sektorów gospodarki [Motowidlak i Fajczak-Kowalska 2010]. W łańcuchu dostaw w sektorze mleczarskim kluczową pozycję zajmują gospodarstwa rolne produkujące mleko surowe oraz spółdzielnie mleczarskie prowadzące skup mleka surowego i produkujące gotowe wyroby mleczne.

Celem niniejszej pracy była analiza kointegracji cen na rynku mleka w Polsce w latach 2010-2019. Dokonano krótkiej charakterystyki szeregów czasowych, złożonych z cen mleka w skupie, cen producenta mleka i cen detalicznych mleka. Aby odpowiedzieć na pytania: (1) czy pomiędzy zmiennymi występuję długoterminowa zależność?; (2) czy istnieje określona relacja pomiędzy zmiennymi w długim okresie?, wykorzystano analizę kointegracji opartą na teście Engle'a- Grangera.

Otrzymane wyniki ujawniły występowanie długookresowej relacji pomiędzy cenami producenta mleka i cenami detalicznymi. Kointegracja tych dwóch zmiennych oznacza istnienie długookresowych mechanizmów dostosowawczych prowadzących do osiągnięcia stanu równowagi dynamicznej. Konkluzją uzyskanych wyników jest stwierdzenie, że rynek producenta oraz rynek detaliczny mleka są ze sobą skointegrowane, co skutkuje rosnącym powiązaniem cen. Określenie, czy pomiędzy cenami w poszczególnych ogniwach łańcucha dostaw istnieje pewna długookresowa równowaga, jest istotne w podejmowaniu decyzji produkcyjnych w dwóch pierwszych ogniwach 
tego łańcucha. Przeprowadzona analiza wskazuje jednak, że pomiędzy cenami w tych ogniwach nie występują zależności długookresowe. Nie można, zatem mówić o występowaniu pewnych analogii w kształtowaniu się cen w badanym okresie. Odmienna sytuacja ma miejsce w przypadku dwóch ostatnich ogniw: procentów i punktów sprzedaży detalicznej. Należy jednak pamiętać, że pomiędzy tymi ogniwami występuje wiele dodatkowych podmiotów pełniących funkcję pośredników. I to oni w dużej mierze wpływają na ostateczny poziom cen detalicznych.

\section{Literatura}

Abt S., 2003: Logistyka ponad granicami, ILiM, Poznań.

Allen D.E., MacDonald G., 1951: The Long-Run Gains from International Equity Diversification. Australian Evidence from Cointegration Tests, [w:] D.K. Ghosh, S. Khaksari (red.), Managerial Finance in the Corporate Economy, Routledge, Londyn, 112.

Batóg B., 2016: Badanie kointegracji wybranych zmiennych ekonomiczno-finansowych w województwie zachodniopomorskim, Studia i Prace Wydziału Nauk Ekonomicznych i Zarządzania Uniwersytetu Szczecińskiego 45, 133-141.

Borzyszkowska M., 2007: Analiza empiryczna wybranych zmiennych wchodzących w skład funkcji popytu na pieniądz, Dynamiczne Modele Ekonometryczne, X Ogólnopolskie Seminarium Naukowe, Uniwersytet Mikołaja Kopernika w Toruniu, [źródło elektroniczne] http://www.dem.umk.pl/DME/2007/borzyszkowska.pdf [dostęp: 07.06.2019].

GUS, 2019: Ceny w rolnictwie, [źródło elektroniczne] https://bdl.stst.gov.pl/BDL/dane/podgrup/ temat [dostęp: 05.06.2019].

Jarczyński J., 2003: Charakterystyka logistycznego łańcucha dostaw w zakresie przepływu surowców i wyrobów gotowych w wybranych spółdzielniach mleczarskich, Logistyka 2.

Jarzembowski S., 2013: Łańcuchy dostaw w gospodarce żywnościowej, Zeszyty Naukowe SGGW w Warszawie. Ekonomika i Organizacja Gospodarki Żywnościowej 103.

Kapusta F., 2009: Logistyczny łańcuch mleka w Polsce, cz. I, Przegląd Mleczarski 6.

Mikołajczyk K., Wyrobek J., 2006: Możliwość wykorzystania metody autoregresji wektorowej w polityce pieniężnej, Zeszyty Naukowe Akademii Ekonomicznej w Krakowie 683, 63-87.

Morkis G., Nosecka B., Seremak-Bulge J., 2010: Monitorowanie oraz analiza zmian polskiego łańcucha żywnościowego. Synteza z realizacji tematu III, Instytut Ekonomiki Rolnictwa i Gospodarki Żywnościowej - Państwowy Instytut Badawczy, Warszawa.

Motowidlak U., Fajczak-Kowalska A., 2010: Wartość dodana w łańcuchu dostaw żywności, Zeszyty Naukwoe SGGW w Warszawie. Problemy Rolnictwa Światowego 10, 2.

Promowanie pozycjonowania rolników i spółdzielni w łańcuchu dostaw żywności, 2019, [źródło elektroniczne] www.eurodetachement-travail.eu/datas/files/EUR/gopa\%20pol.pdf [dostęp: 07.06.2019].

Przekota G., Rembeza J., 2016: Powiązania dynamiki wzrostu gospodarczego pomiędzy krajami Europy Środkowo-Wschodniej i Europy Zachodniej, Roczniki Ekonomiczne KujawskoPomorskiej Szkoły Wyższej w Bydgoszczy 9, 123-140.

Szymańska E., Bórawski P., Żuchowski I., 2018: Łańcuchy dostaw na wybranych rynkach rolnych w Polsce, Wydawnictwo SGGW, Warszawa. 
Tatarczak E., 2007: Badanie stacjonarności oraz kointegracji kursów walutowych, Roczniki Nauk Rolniczych, Seria G, 94, 1, 149-156.

Tłuczak A., 2015: Zależności cenowe w łańcuchach dostaw żywności na przykładzie cen mięsa, Studia Ekonomiczne, Zeszyty Naukowe Uniwersytetu Ekonomicznego w Katowicach 249.

Tłuczak A., 2016: Analiza zmian cen w łańcuchach dostaw żywności na przykładzie rynku mięsa wołowego w Polsce, Zeszyty Naukowe SGGW w Warszawie. Ekonomika i Organizacja Logistyki 1.

Adres do korespondencji:

dr inż. Agnieszka Tluczak (https://orcid.org/0000-0001-6217-8822)

Wydział Ekonomiczny Uniwersytet Opolski ul. Ozimska 46a, 45-058 Opole e-mail: atluczak@uni.opole.pl 
ISSN 2450-8055 